In cooperation with the City of Cedar Rapids

\title{
Selected Water-Quality Data from the Cedar River and Cedar Rapids Well Fields, Cedar Rapids, lowa, 1999-2005
}

Data Series 494 



\section{Selected Water-Quality Data from the Cedar River and Cedar Rapids Well Fields, Cedar Rapids, lowa, 1999-2005}

By Gregory R. Littin and Douglas J. Schnoebelen

Prepared in cooperation with the City of Cedar Rapids

Data Series 494 


\title{
U.S. Department of the Interior \\ KEN SALAZAR, Secretary \\ U.S. Geological Survey \\ Marcia K. McNutt, Director
}

\section{U.S. Geological Survey, Reston, Virginia: 2010}

\author{
For more information on the USGS — the Federal source for science about the Earth, its natural and living resources, \\ natural hazards, and the environment, visit http://www.usgs.gov or call 1-888-ASK-USGS \\ For an overview of USGS information products, including maps, imagery, and publications, \\ visit http://www.usgs.gov/pubprod \\ To order this and other USGS information products, visit http://store.usgs.gov
}

\begin{abstract}
Any use of trade, product, or firm names is for descriptive purposes only and does not imply endorsement by the U.S. Government.

Although this report is in the public domain, permission must be secured from the individual copyright owners to reproduce any copyrighted materials contained within this report.
\end{abstract}

Suggested citation:

Littin, G.R., and Schnoebelen, D.J., 2010, Selected water-quality data from the Cedar River and Cedar Rapids well fields, Cedar Rapids, lowa, 1999-2005: U.S. Geological Survey, Data Series 494, 52 p. 


\section{Contents}

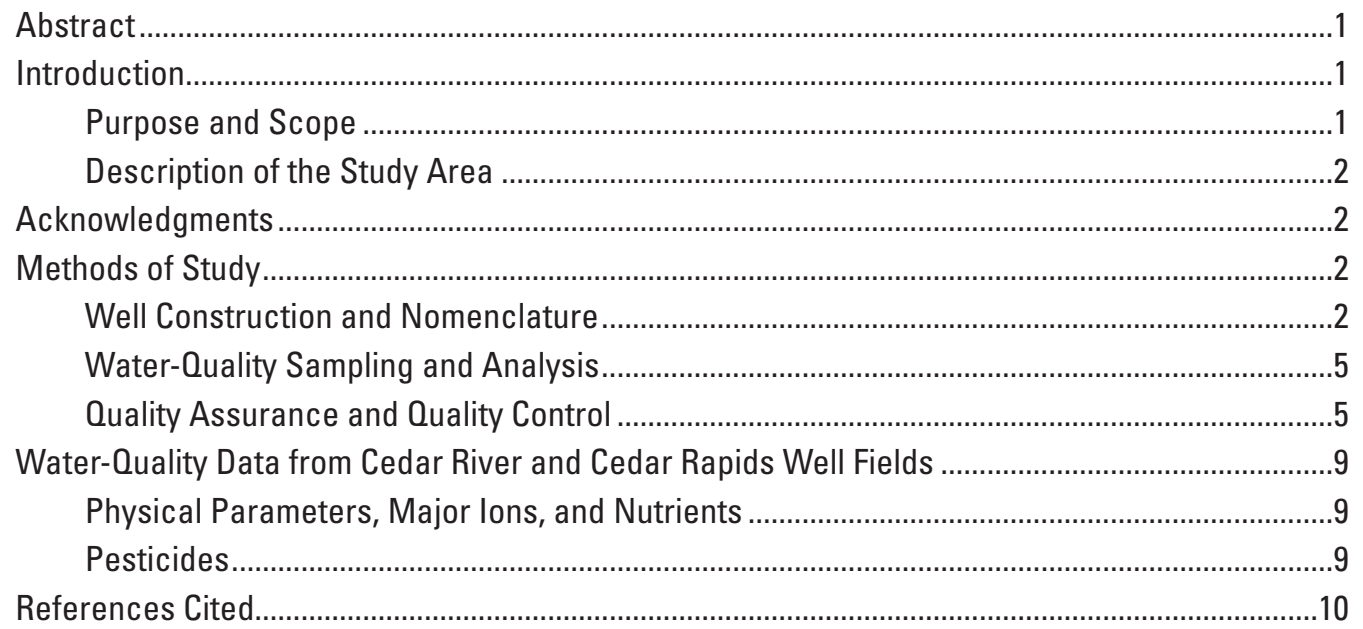

\section{Figures}

1. Groundwater and surface-water quality data-collection sites, Cedar Rapids, lowa

\section{Tables}

1. Information for groundwater and surface-water quality data-collection sites, Cedar Rapids, lowa, calendar years 1999-2005.

2. Nutrients and dissolved organic carbon, field parameters tested for in water-quality samples, and reporting units..

3. Major ions tested for in water-quality samples, and reporting units................................6

4. Selected pesticides and pesticide degradates tested for in water-quality samples, and reporting units

5. Summary of replicate water-quality data for nutrients, major ions, pesticides and pesticide degradates, Cedar Rapids, lowa, calendar years 1999-2005

6. Surrogate pesticide data for samples from groundwater and surface-water sampling sites with minimum, maximum, median, and mean percent recovery, Cedar Rapids, lowa, calendar years 1999-2005.

7. Physical parameters, summary statistics of groundwater and surface-water quality data combined, Cedar Rapids, lowa, calendar years 1999-2005.

8. Physical parameters, summary statistics of groundwater and surface-water quality data by site, Cedar Rapids, lowa, calendar years 1999-2005

9. Major ions, summary statistics of groundwater and surface-water quality data combined, Cedar Rapids, lowa, calendar years 1999-2005

10. Major ions, summary statistics of water-quality data for groundwater and surface-water sampling sites, Cedar Rapids, lowa, calendar years 1999-2005 
11. Nutrients, summary statistics of groundwater and surface-water quality data combined, Cedar Rapids, lowa, calendar years 1999-2005.

12. Nutrients, summary statistics of water-quality data for groundwater and surface-water sampling sites, Cedar Rapids, lowa, calendar years 1999-2005

13. Major ions and nutrients, summary statistics of groundwater and surface-water quality data by site, Cedar Rapids, lowa, calendar years 1999-2005

14. Information on pesticides and pesticide degradates tested at water-quality sampling sites, Cedar Rapids, lowa, calendar years 1999-2005

15. Pesticides that were not detected in water-quality samples, Cedar Rapids, lowa, calendar years 1999-2005

16. Pesticide degradates that were not detected in water-quality samples, Cedar Rapids, lowa, calendar years 1999-2005.

17. Selected pesticides and pesticide degradates, frequency of detections for groundwater and surface-water samples combined, Cedar Rapids, lowa, calendar years 1999-2005.

18. Selected pesticides and pesticide degradates, frequency of detections in groundwater and surface-water samples, Cedar Rapids, lowa, calendar years 1999-2005.

19. Selected pesticides and pesticide degradates, frequency of detections in groundwater and surface-water samples by site, Cedar Rapids, lowa, calendar years 1999-2005.

20. Pesticide degradates data by site, Cedar Rapids, lowa, calendar years 1999-2005 


\section{Conversion Factors and Datums}

\begin{tabular}{lcl}
\hline \multicolumn{1}{c}{ Multiply } & \multicolumn{1}{c}{ By } & \multicolumn{1}{c}{ To obtain } \\
\hline inch (in.) & Length & \\
foot (ft) & 2.54 & centimeter $(\mathrm{cm})$ \\
mile (mi) & 0.3048 & meter $(\mathrm{m})$ \\
\hline & 1.609 & kilometer $(\mathrm{km})$ \\
\hline acre & Area & \\
square mile $\left(\mathrm{mi}^{2}\right)$ & 4,047 & square meter $\left(\mathrm{m}^{2}\right)$ \\
& 2.590 & square kilometer $\left(\mathrm{km}^{2}\right)$ \\
\hline cubic foot $\left(\mathrm{ft}^{3}\right)$ & Volume & \\
quart (qt) & 0.02832 & cubic meter $\left(\mathrm{m}^{3}\right)$ \\
million gallons (Mgal) & 0.9464 & liter $(\mathrm{L})$ \\
\hline & 3,785 & cubic meter $\left(\mathrm{m}^{3}\right)$ \\
\hline cubic foot per second (ft $3 / \mathrm{s})$ & Flow rate & \\
million gallons per day $(\mathrm{Mgal} / \mathrm{d})$ & 0.02832 & cubic meter per second $\left(\mathrm{m}^{3} / \mathrm{s}\right)$ \\
\hline & 0.04381 & cubic meter per second $\left(\mathrm{m}^{3} / \mathrm{s}\right)$ \\
\hline ounce, avoirdupois $(\mathrm{oz})$ & Mass & gram $(\mathrm{g})$ \\
pound, avoirdupois $(\mathrm{lb})$ per year $(\mathrm{yr})$ & 28.35 & kilogram $(\mathrm{kg})$ per year $(\mathrm{yr})$ \\
\hline
\end{tabular}

Temperature in degrees Celsius $\left({ }^{\circ} \mathrm{C}\right)$ may be converted to degrees Fahrenheit $\left({ }^{\circ} \mathrm{F}\right)$ as follows:

$$
{ }^{\circ} \mathrm{F}=\left(1.8 \times^{\circ} \mathrm{C}\right)+32
$$

Temperature in degrees Fahrenheit $\left({ }^{\circ} \mathrm{F}\right)$ may be converted to degrees Celsius $\left({ }^{\circ} \mathrm{C}\right)$ as follows:

$$
{ }^{\circ} \mathrm{C}=\left({ }^{\circ} \mathrm{F}-32\right) / 1.8
$$

Vertical coordinate information is referenced to the insert datum name (and abbreviation) here for instance, "North American Vertical Datum of 1988 (NAVD 88)."

Horizontal coordinate information is referenced to the insert datum name (and abbreviation) here for instance, "North American Datum of 1983 (NAD 83)."

Altitude, as used in this report, refers to distance above the vertical datum.

*Transmissivity: The standard unit for transmissivity is cubic foot per day per square foot times foot of aquifer thickness [(ft3/d)/ft2]ft. In this report, the mathematically reduced form, foot squared per day (ft2/d), is used for convenience.

Specific conductance is given in microsiemens per centimeter at 25 degrees Celsius $(\mu \mathrm{S} / \mathrm{cm}$ at $\left.25^{\circ} \mathrm{C}\right)$.

Concentrations of chemical constituents in water are given either in milligrams per liter (mg/L) or micrograms per liter $(\mu \mathrm{g} / \mathrm{L})$. 



\title{
Selected Water-Quality Data from the Cedar River and Cedar Rapids Well Fields, Cedar Rapids, lowa, 1999-2005
}

\author{
By Gregory R. Littin and Douglas J. Schnoebelen
}

\section{Abstract}

The Cedar River alluvial aquifer is the primary source of municipal water in the Cedar Rapids, Iowa area. Municipal wells are completed in the alluvial aquifer at approximately 40 to 80 feet deep. The City of Cedar Rapids and the U.S. Geological Survey have been conducting a cooperative study of the groundwater-flow system and water quality near the well fields since 1992. Previous cooperative studies between the City of Cedar Rapids and the U.S. Geological Survey have documented hydrologic and water-quality data, geochemistry, and groundwater models. Water-quality samples were collected for studies involving well field monitoring, trends, source-water protection, groundwater geochemistry, evaluation of surface and ground-water interaction, assessment of pesticides in groundwater and surface water, and to evaluate water quality near a wetland area in the Seminole well field. Typical water-quality analyses included major ions (boron, bromide, calcium, chloride, fluoride, iron, magnesium, manganese, potassium, silica, sodium, and sulfate), nutrients (ammonia as nitrogen, nitrite as nitrogen, nitrite plus nitrate as nitrogen, and orthophosphate as phosphorus), dissolved organic carbon, and selected pesticides including two degradates of the herbicide atrazine. In addition, two synoptic samplings included analyses of additional pesticide degradates in water samples. Physical field parameters (alkalinity, dissolved oxygen, $\mathrm{pH}$, specific conductance and water temperature) were recorded with each water sample collected. This report presents the results of water quality data-collection activities from January 1999 through December 2005. Methods of data collection, quality-assurance samples, water-quality analyses, and statistical summaries are presented. Data include the results of water-quality analyses from quarterly and synoptic sampling from monitoring wells, municipal wells, and the Cedar River.

\section{Introduction}

The city of Cedar Rapids, in Linn County, Iowa, obtains its municipal water supply from a shallow alluvial aquifer adjacent to the Cedar River. Fifty-three vertical wells and four horizontal collector wells are completed at about 40 to 80 feet (ft) deep. Vertical wells gradually are being replaced by higher-yielding horizontal collector wells, but many of the vertical wells remain regularly used or in standby operation. Adequate quantities of generally high-quality water have been obtained from the alluvial aquifer since the resource was developed in 1962; however, increasing population and industrial development have increased the demand for municipal water. Cedar Rapids pumped about 40 million gallons per day (Mgal/d) from the alluvial aquifer in 2005 although peak demands have reached $50 \mathrm{Mgal} / \mathrm{d}$ at certain times, typically during the summer months (City of Cedar Rapids Water Department, oral commun., February 2006).

The City of Cedar Rapids and the U.S. Geological Survey (USGS) have been conducting a cooperative study of the groundwater-flow system, surface-water system, and water quality in and near the well fields since 1992. Schulmeyer (1995) analyzed the effect of the Cedar River on the quality of ground water near the municipal well fields. Schnoebelen and Schulmeyer (1996) documented hydrogeologic data collected and compiled from October 1992 to March 1996. Schulmeyer and Schnoebelen (1998) described the hydrogeology near the municipal well fields, documented a groundwater-flow model constructed to simulate regional groundwater flow under steady-state conditions, identified sources of water to the municipal well fields, and assessed temporal and spatial variations of selected water-quality constituents and properties. Boyd (1998) characterized groundwater flow near the municipal well fields with selected environmental isotopes and tracers. Boyd (1999) evaluated the occurrence and distribution of selected pesticide and pesticide degradate concentrations in the alluvial aquifer and Cedar River following springtime application of these pesticides to upstream cropland areas. Boyd and others (1999) further documented hydrogeologic data collected in the Cedar Rapids area from April 1996 to March 1999.

\section{Purpose and Scope}

This report presents the results of water quality data-collection activities from January 1999 through December 2005 for the cooperative study between the City of Cedar Rapids, 
Iowa, and the USGS. Data presented in this report include results of water-quality analyses and physical field properties of water samples measured during sample collection from the Cedar River and wells in the Cedar Rapids municipal well fields.

\section{Description of the Study Area}

Cedar Rapids is within Linn County in east-central Iowa; water for the city of Cedar Rapids is supplied from three well fields (Seminole, East, and West) along the Cedar River (fig. 1). The city of Cedar Rapids has a population of about 121,000 (U.S. Census Bureau, 2000). Several large industries are major water users resulting in a per capita water usage that is nearly three times the national average for a city of this size (Cedar Rapids Water Department, written commun., February 2004). The Cedar River Basin drains an area of about 6,510 square miles $\left(\mathrm{mi}^{2}\right)$ upstream from the streamgaging station at Cedar Rapids (Cedar River at Cedar Rapids, USGS station number 05464500). Upstream land use is greater than 90 percent agriculture; corn and soybeans are the major crops. Livestock raised in the area include cattle and hogs. Annual precipitation averages about 36 inches per year (in/yr) in the Cedar Rapids area (National Oceanic and Atmospheric Administration, 1999). Extreme daily mean flows recorded at the streamgaging station during the study were 61,800 cubic feet per second $\left(\mathrm{ft}^{3} / \mathrm{s}\right.$; May 27,2004$)$ and $326 \mathrm{ft}^{3} / \mathrm{s}$ (January 12, 2003; Nalley and others, 2005). Extreme daily mean flows recorded during the period of record (1903 to 2005) were 71,500 ft ${ }^{3} / \mathrm{s}$ (March $31,1961)$ and $140 \mathrm{ft}^{3} / \mathrm{s}$ (November 18, 1989; Nalley and others, 2006).

Hydrogeologic units in and near the well fields consist of an unconsolidated surficial layer of glacial till, loess, and the Cedar River alluvium (alluvial aquifer), underlain by carbonate bedrock of Devonian and Silurian age. The flood plain ranges from about 1,000 to $3,300 \mathrm{ft}$ wide in the study area. The upland topography is characterized by rolling hills of low relief. Typically, glacial till and loess form upland areas that bound the alluvial aquifer. The alluvial aquifer ranges from 5 to $95 \mathrm{ft}$ thick near the well fields and consists of a sequence of coarse sand and gravel at the base, grading upward to fine sand, silt, and clay near the surface. The thickness of the alluvium decreases as distance from the Cedar River increases; the thinnest alluvium is adjacent to the valley walls. The alluvial valley is bounded by steep bluffs that rise almost $200 \mathrm{ft}$ above the river floodplain and, in places, include bedrock exposures. The bedrock aquifer has a maximum thickness of about 700 $\mathrm{ft}$ near the well fields. The bedrock aquifer primarily consists of jointed and fractured limestone and dolomite, with some interbedded chert and shale (Schulmeyer and Schnoebelen, 1998). There are no municipal wells completed in the bedrock aquifer, but it is used locally by private landowners and some industrial users. The unconsolidated surficial layers, carbonate bedrock of Devonian and Silurian age, and deeper hydrogeo- logic units are described in detail by Hansen (1970), Wahl and Bunker (1986), and Schulmeyer and Schnoebelen (1998).

The alluvial aquifer is recharged by infiltration from the Cedar River, precipitation, and seepage from the underlying bedrock and adjacent hydrogeologic units. In areas affected by municipal pumping, groundwater flow is from the Cedar River toward the well fields; in areas outside the affect of municipal pumping, groundwater flow is toward the Cedar River. The Cedar River is in direct hydraulic connection with the alluvial aquifer (Turco and Buchmiller, 2004). Hansen (1970) calculated an approximate transmissivity of the alluvial aquifer to be about 20,000 feet squared per day $\left(\mathrm{ft}^{2} / \mathrm{d}\right)$. Subsequent investigations by Schulmeyer (1995) indicate that the transmissivity ranges from about 1,500 to $19,000 \mathrm{ft}^{2} / \mathrm{d}$, depending on the physical properties of the alluvium. In May 2006, a contractor to the City of Cedar Rapids performed an aquifer test using Seminole well 10 (an abandoned well located on the edge of the river bank). Results of this aquifer test yielded a transmissivity value of approximately $15,000 \mathrm{ft}^{2} / \mathrm{d}$ (Cedar Rapids Water Department, oral commun., March 2007).

\section{Acknowledgments}

The authors thank the personnel of the Cedar Rapids Water Department for their assistance in data collection and construction of monitoring wells.

\section{Methods of Study}

Samples for water-quality analysis were collected from the Cedar River, monitoring wells within the municipal well fields, municipal wells, and the Cedar Rapids J-Avenue waterworks plant. Data include water-quality analyses and physical parameters measured at the time of sample collection. Well locations used for sampling are shown in figure 1. Statistics (minimum, maximum, mean, and median) were compiled for all water-quality samples. In addition, methods of quality assurance of samples are discussed and data on quality-control samples are presented.

\section{Well Construction and Nomenclature}

Wells sampled during the study included 2- and 4-inch (in.) outer-diameter monitoring wells. The monitoring wells were installed using hollow-stem auger drilling techniques and completed with polyvinyl-chloride (PVC) flush-joint casing. Bentonite grout was installed around the casing 6 to $8 \mathrm{ft}$ below land surface and capped with a cement pad at the surface. Well depths ranged from 18 to $47.5 \mathrm{ft}$. Well construction information for all the monitoring wells is listed in table 1 . 

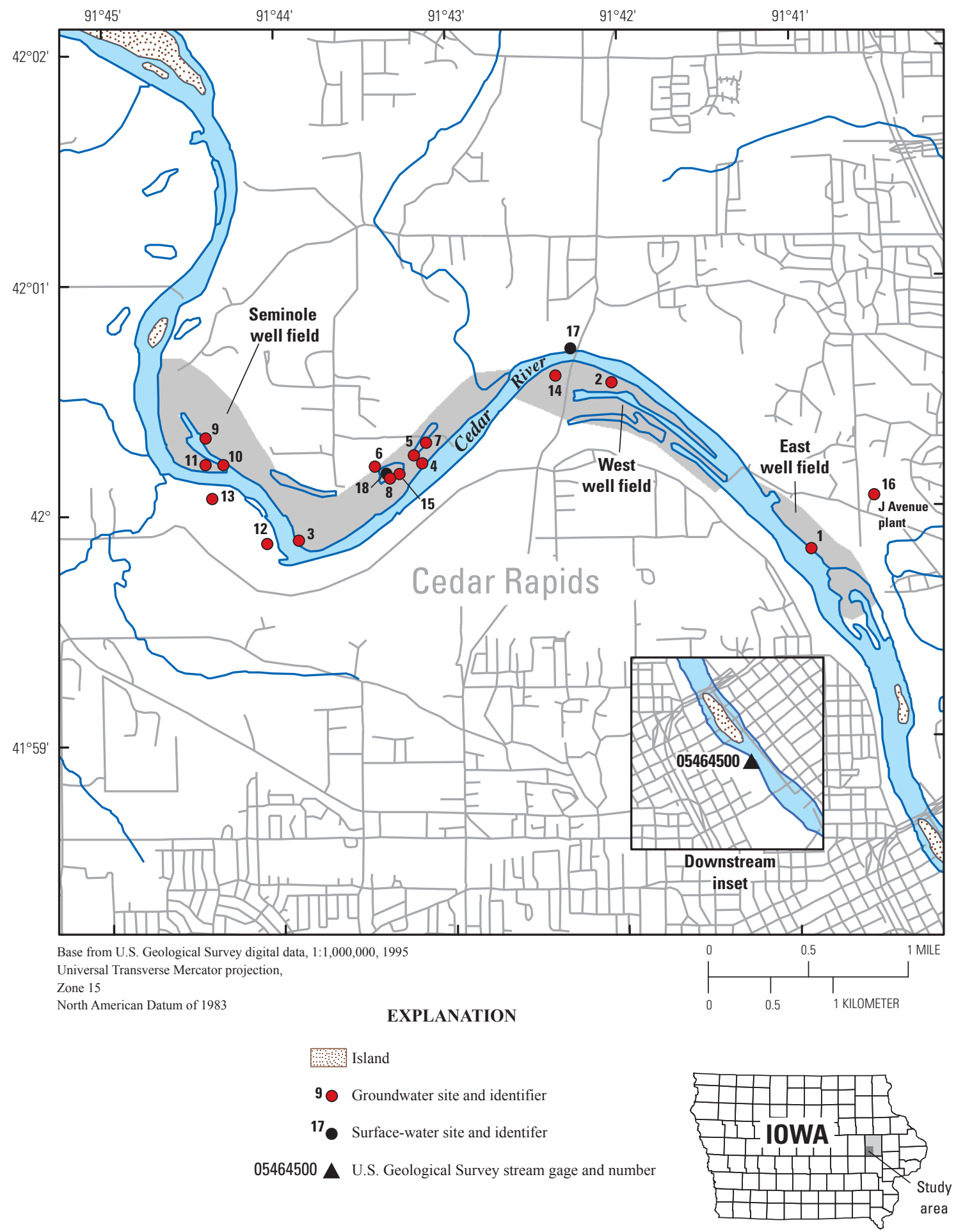

Figure 1. Groundwater and surface-water quality data-collection sites, Cedar Rapids, lowa. 


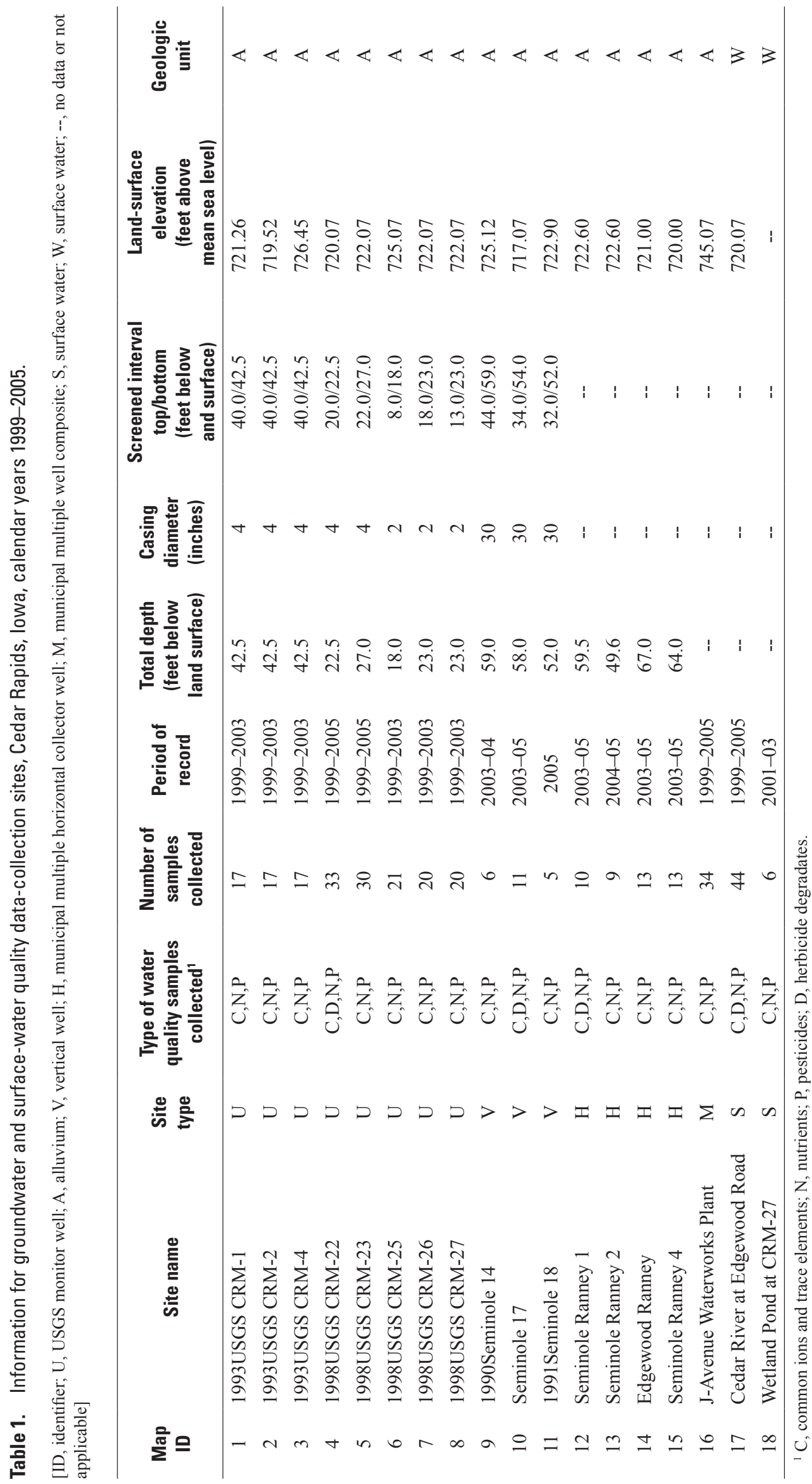


The monitoring wells are named according to a convention that includes the year the well was installed (for example, 1993), the agency identifier (USGS), the local project identifier, (CRM, for Cedar Rapids Municipal), and a unique incremental number (beginning with number 1). For example, well 1993 USGS CRM 1 is the first well installed by the USGS in 1993 for CRM. For convenience in this report, the year and agency identifier typically will not be included when referring to a site name.

Municipal wells used by the city of Cedar Rapids are identified with the first letter of the well field name (S, Seminole, E, East, and W, West) then the well number (for example Seminole 1 is S1). In addition, horizontal collector wells that have been added to the well fields during the last 15 years are identified as a "Ranney well".

\section{Water-Quality Sampling and Analysis}

Water-quality samples were collected from the Cedar River, 2- and 4-in. diameter monitoring wells, municipal wells, and the J-Avenue waterworks plant (municipal-well raw-water composite). Water-quality samples were collected for various project needs from January 1999 through December, 2005, which included quarterly water samples, synoptic water samples, and water samples documenting groundwater and surface-water interaction near a wetland.

Before collecting water samples, each monitoring well was pumped to remove approximately three borehole volumes of water. Water samples were collected using a stainless-steel submersible pump and chemically inert fluoropolymer tubing. Onsite measurements of air temperature, alkalinity, air pressure, dissolved oxygen, $\mathrm{pH}$, specific conductance and water temperature were performed at the time of sample collection. Measurement of dissolved oxygen, $\mathrm{pH}$, specific conductance, and water temperature were measured in a flow-through chamber for groundwater only. Water samples for analysis of nutrients and major ions were filtered through a 0.45 -micrometer $(\mu \mathrm{m})$ pore size polycarbonate capsule filter in the field. Water samples for pesticide analysis were filtered through a 142-millimeter $(\mathrm{mm})$ diameter, $0.7-\mu \mathrm{m}$ pore size, borosilicate glass-fiber filter baked at 450 degrees Celsius $\left({ }^{\circ} \mathrm{C}\right)$, and placed in a stainless steel filter unit. All samples were collected according to USGS protocols (U.S. Geological Survey, 2006). Water samples were kept chilled and shipped by overnight air express to the USGS National Water-Quality Laboratory (NWQL) in Denver, Colorado, for analysis.

Nutrients, dissolved organic carbon, and field parameters tested for in the water-quality samples, the Chemical Abstract Service Registry Number (CASRN), the National Water Information System (NWIS) parameter code, laboratory reporting levels (LRL), and reporting units are listed in table 2. This report contains CAS Registry Numbers ${ }^{\circledR}$, which is a Registered Trademark of the American Chemical Society. CAS recommends the verification of the CASRNs through CAS Client ServicesSM. The term "nitrate" as used in this report includes the nitrite species as this form of the nitrogen species typically is a small concentration (less than $0.1 \mathrm{mg} / \mathrm{L}$ ). The major ions and selected pesticides with two pesticide degradate compounds, followed by the CASRN number, NWIS parameter code, and LRLs are listed in tables 3 and 4, respectively. The LRL is used for specifying the lowest quantifiable value for constituents listed tables 2, 3, and 4 (unless footnoted otherwise). The LRLs for many of the constituents varied for the period of record covered by this report. The LRL is defined more rigorously by statistics than the older minimum reporting level (MRL) that it replaces at the NWQL (Oblinger-Childress and others, 1999).

\section{Quality Assurance and Quality Control}

To properly interpret water-quality data and to verify that these data are reliable and accurate, quality-assurance (QA) procedures and quality-control (QC) samples are needed. In general, quality assurance includes using correct procedures and protocols, proper documentation (log books and field sheets), and approved analytical methods. The QC samples typically estimate the magnitude of bias and variability of the environmental samples. Bias is systematic error that can "skew" results in either a positive or negative direction. The most common source of positive bias in water-quality studies is contamination of samples from airborne gases and particulates, or inadequately cleaned sampling equipment between uses and locations. Variability is the degree of random error of independent measurements of the sample quantity. Variability may be the result of errors in laboratory analytical procedures or in collection of samples in the field. The QA/QC procedures are required to ensure that the data collected meet standards of reliability and accuracy.

The QA/QC procedures for the study followed USGS protocols (USGS, 2006) and other USGS guidelines (Mueller and others, 1997). Approximately 10 percent of the total samples collected for the study were analyzed for quality control and included equipment blanks, field blanks, and replicates. Generally, blanks are used to estimate sample bias, whereas replicates are used to estimate sample variability.

A blank is a water sample that is intended to be free of the analytes of interest. Blank samples of deionized water guaranteed by the manufacturer to be free of organic compounds and another type of deionized water guaranteed by the manufacturer to be free of inorganic compounds were passed through all sampling equipment at the beginning of the field season. Equipment blank samples are collected in a "clean" environment such as the laboratory to examine the cleanliness of the equipment before sampling. A field blank is a specific type of blank sample collected in the field and used to demonstrate that (1) equipment has been adequately cleaned to remove contamination introduced by samples obtained at the previous site; (2) sample collection and processing have not resulted in contamination; and (3) sample handling, transport, and laboratory analysis have not introduced contamination 
Table 2. Nutrients and dissolved organic carbon, field parameters tested for in waterquality samples, and reporting units.

[CASRN, Chemical Abstract Service Registry Number; NWIS, National Water Information System; LRLs, laboratory reporting levels; mg/L, milligrams per liter; --, not applicable; $\mu \mathrm{S} / \mathrm{cm}$, microsiemens per centimeter]

\begin{tabular}{lcccc}
\hline \multicolumn{1}{c}{$\begin{array}{c}\text { Water-quality } \\
\text { constituent }\end{array}$} & $\begin{array}{c}\text { CASRN } \\
\text { number }\end{array}$ & $\begin{array}{c}\text { NWIS } \\
\text { parameter } \\
\text { code }\end{array}$ & LRLs & $\begin{array}{c}\text { Reporting } \\
\text { units }\end{array}$ \\
\hline \multicolumn{2}{c}{ Nutrients and dissolved organic carbon } \\
\hline Nitrogen, ammonia, as N & $7664-41-7$ & 00608 & $0.02-.04$ & $\mathrm{mg} / \mathrm{L}$ \\
Nitrogen, nitrate + nitrite, as N & -- & 00631 & $.06-.047$ & $\mathrm{mg} / \mathrm{L}$ \\
Nitrogen, nitrite, as N & $14797-65-0$ & 00613 & $.01-.008$ & $\mathrm{mg} / \mathrm{L}$ \\
Phosphorus, ortho, as P & $14265-44-2$ & 00671 & $.01-.02$ & $\mathrm{mg} / \mathrm{L}$ \\
Dissolved organic carbon & -- & 00681 & .40 & $\mathrm{mg} / \mathrm{L}$ \\
\hline & Field parameters & & \\
\hline Alkalinity & -- & 39086 & -- & $\mathrm{mg} / \mathrm{L}$ \\
Dissolved oxygen & -- & 31501 & -- & $\mathrm{mg} / \mathrm{L}$ \\
pH & -- & 00400 & -- & $\mathrm{Standard}$ \\
Specific conductance & -- & 00095 & -- & $\mu \mathrm{units}$ \\
Temperature, water & -- & 00010 & -- & Degrees \\
\end{tabular}

Table 3. Major ions tested for in water-quality samples, and reporting units.

[CASRN, Chemical Abstract Service Registry Number; NWIS, National Water Information System; LRLs, laboratory reporting levels; $\mu \mathrm{g} / \mathrm{L}$, micrograms per liter; $\mathrm{mg} / \mathrm{L}$, milligrams per liter; --, not applicable; $\mu \mathrm{S} / \mathrm{cm}$, microsiemens per centimeter]

\begin{tabular}{lcccc}
\hline \multicolumn{1}{c}{$\begin{array}{c}\text { Water-quality } \\
\text { constituent }\end{array}$} & $\begin{array}{c}\text { CASRN } \\
\text { number }\end{array}$ & $\begin{array}{c}\text { NWIS } \\
\text { parameter } \\
\text { code }\end{array}$ & LRLs & $\begin{array}{c}\text { Reporting } \\
\text { units }\end{array}$ \\
\hline Boron & $7440-42-8$ & 01020 & 1.8 & $\mu \mathrm{g} / \mathrm{L}$ \\
Bromide & $24959-67-9$ & 71870 & $.2-.01$ & $\mathrm{mg} / \mathrm{L}$ \\
Calcium & $7440-70-2$ & 00915 & .02 & $\mathrm{mg} / \mathrm{L}$ \\
Calcium bicarbonate & $3983-19-5$ & 00453 & .02 & $\mathrm{mg} / \mathrm{L}$ \\
Calcium carbonate & $471-34-1$ & 00442 & .02 & $\mathrm{mg} / \mathrm{L}$ \\
Chloride & $16887-00-6$ & 00940 & .12 & $\mathrm{mg} / \mathrm{L}$ \\
Fluoride & $16984-48-8$ & 00950 & $.17-.04$ & $\mathrm{mg} / \mathrm{L}$ \\
Iron & $7439-89-6$ & 01046 & $8.0-6.0$ & $\mu \mathrm{g} / \mathrm{L}$ \\
Magnesium & $7439-95-4$ & 00925 & .014 & $\mathrm{mg} / \mathrm{L}$ \\
Manganese & $7439-96-5$ & 01056 & $3.2-2.2$ & $\mu \mathrm{g} / \mathrm{L}$ \\
Potassium & $7440-09-7$ & 00935 & .04 & $\mathrm{mg} / \mathrm{L}$ \\
Silica & $7631-86-9$ & 00955 & .018 & $\mathrm{mg} / \mathrm{L}$ \\
Sodium & $7440-23-5$ & 00930 & .02 & $\mathrm{mg} / \mathrm{L}$ \\
Sulfate & $14808-79-8$ & 00945 & .1 & $\mathrm{mg} / \mathrm{L}$ \\
Total dissolved solids & -- & 70300 & 10 & $\mathrm{mg} / \mathrm{L}$ \\
\hline
\end{tabular}


Table 4. Selected pesticides and pesticide degradates tested for in water-quality samples, and reporting units.

[CASRN, Chemical Abstract Service Registry Number; NWIS, National Water Information System; LRLs, laboratory reporting levels; $\mu \mathrm{g} / \mathrm{L}$, micrograms per liter]

\begin{tabular}{|c|c|c|c|c|}
\hline $\begin{array}{c}\text { Water-quality } \\
\text { constituent }\end{array}$ & $\begin{array}{l}\text { CASRN } \\
\text { number }\end{array}$ & $\begin{array}{c}\text { NWIS } \\
\text { parameter } \\
\text { code }\end{array}$ & LRLs & $\begin{array}{l}\text { Reporting } \\
\text { units }\end{array}$ \\
\hline CIAT $^{1}$ & $6190-65-4$ & 04040 & 0.05 & $\mu \mathrm{g} / \mathrm{L}$ \\
\hline CEAT $^{1}$ & $1007-28-9$ & 04038 & .05 & $\mu \mathrm{g} / \mathrm{L}$ \\
\hline Acetochlor & $34256-82-1$ & 49260 & .05 & $\mu \mathrm{g} / \mathrm{L}$ \\
\hline Alachlor & $15972-60-8$ & 46342 & .05 & $\mu \mathrm{g} / \mathrm{L}$ \\
\hline Ametryn & $834-12-8$ & 38401 & .05 & $\mu \mathrm{g} / \mathrm{L}$ \\
\hline Atrazine & $1912-24-9$ & 39632 & .05 & $\mu \mathrm{g} / \mathrm{L}$ \\
\hline Bromacil & $314-40-9$ & 04029 & .05 & $\mu \mathrm{g} / \mathrm{L}$ \\
\hline Butachlor & 23184-66-9 & 04026 & .05 & $\mu \mathrm{g} / \mathrm{L}$ \\
\hline Butylate & $2008-41-5$ & 04028 & .05 & $\mu \mathrm{g} / \mathrm{L}$ \\
\hline Carboxin & $5234-68-4$ & 04027 & .05 & $\mu \mathrm{g} / \mathrm{L}$ \\
\hline Cyanazine & $21725-46-2$ & 04041 & .20 & $\mu \mathrm{g} / \mathrm{L}$ \\
\hline Cycloate & $1134-23-2$ & 04031 & .05 & $\mu \mathrm{g} / \mathrm{L}$ \\
\hline Diphenamid & $957-51-7$ & 04033 & .05 & $\mu \mathrm{g} / \mathrm{L}$ \\
\hline Hexazinone & $51235-04-2$ & 04025 & .05 & $\mu \mathrm{g} / \mathrm{L}$ \\
\hline Metolachlor & $51218-45-2$ & 39415 & .05 & $\mu \mathrm{g} / \mathrm{L}$ \\
\hline Metribuzin & 21087-64-9 & 82630 & .05 & $\mu \mathrm{g} / \mathrm{L}$ \\
\hline Prometon & $1610-18-0$ & 04037 & .05 & $\mu \mathrm{g} / \mathrm{L}$ \\
\hline Prometryn & $7287-19-6$ & 04036 & .05 & $\mu \mathrm{g} / \mathrm{L}$ \\
\hline Propachlor & $1918-16-7$ & 04024 & .05 & $\mu \mathrm{g} / \mathrm{L}$ \\
\hline Propazine & $139-40-2$ & 38535 & .05 & $\mu \mathrm{g} / \mathrm{L}$ \\
\hline Simazine & $122-34-9$ & 04035 & .05 & $\mu \mathrm{g} / \mathrm{L}$ \\
\hline Simetryn & $1014-70-6$ & 04030 & .05 & $\mu \mathrm{g} / \mathrm{L}$ \\
\hline Terbacil & $5902-51-2$ & 04032 & .05 & $\mu \mathrm{g} / \mathrm{L}$ \\
\hline Trifluralin & $1582-09-8$ & 04023 & .05 & $\mu \mathrm{g} / \mathrm{L}$ \\
\hline Vernolate & $1929-77-7$ & 04034 & .05 & $\mu \mathrm{g} / \mathrm{L}$ \\
\hline
\end{tabular}

${ }^{1}$ Atrazine degradates: 2-Chloro-4-amino-6-isopropyl-amino-striazine (CIAT) and 2-Chloro-4-ethylamino-6-amino-s-triazine (CEAT).

(Mueller and others, 1997). Field blank samples of the deionized inorganic and organic free water were collected by passing the water through all pumps, filter plates, and filters to verify cleanliness of sampling equipment and technique. Field blank sample concentrations for inorganic and organic constituents typically were below the LRL. Otherwise stated, the blanks were "clean" and did not indicate any contamination from the equipment or sample processing methods. Results signify no cross-contamination of samples from sampling equipment between sample collection.

Replicates are two or more samples collected or processed so that the samples are considered to be essentially identical in composition. Each replicate sample is an aliquot of the native water sample that is processed and prepared in the same way as the environmental sample. A replicate sample set consists of two samples - a regular environmental sample and the replicate environmental sample. For the purposes of this report, the terms "environmental sample" and "replicate sample" are used to identify the particular samples in a replicate pair.

One objective of the replicate samples was to estimate the precision of concentration values from sample processing and analysis. Analysis of organic constituents generally are more variable than analyses of inorganic constituents. Replicate samples were compared by using relative percent differences (RPD). RPD between replicate samples was calculated by the following:

$$
\mathrm{RPD}=|\mathrm{S} 1-\mathrm{S} 2| /(\mathrm{S} 1+\mathrm{S} 2 / 2) \times 100
$$

where

S1 is equal to the concentration in the environmental sample, [given as micrograms per liter $(\mu \mathrm{g} / \mathrm{L})$ or milligrams per liter $(\mathrm{mg} / \mathrm{L})$ ]

and

$$
\begin{aligned}
& \text { S2 is equal to the concentration in the replicate } \\
& \text { sample (given as same units as S1). }
\end{aligned}
$$

A large relative percent difference can indicate greater variability between samples. Variability for all constituents in the replicate samples generally were within 10 percent of the environmental samples. The median RPD for nutrients, organic carbon, and common ions ranged from 0 to 9.5 percent, and the median RPD for pesticides ranged from 0.1 to 5.3 percent (table 5). It should be noted that when comparing small or low concentrations between some replicate samples, the RPD can appear relatively large, because slight differences (common at the lowest detection levels) can result in higher RPDs. This typcially is the case for individual RPDs that had the largest percentage (10 percent or greater).

Surrogates are added to all environmental and qualitycontrol samples for pesticide analysis before sample preparation in the laboratory. A surrogate has similar physical and chemical properties to the analytes of interest, but is not normally present in environmental samples. Surrogates provide quality control by monitoring matrix effects and gross processing errors (Wershaw and others, 1987), and help control for bias, either positive or negative. Surrogate recoveries of organic chemicals are expressed in percent and typically range from 80 to 120 percent. Surrogate recoveries that consistently are less than 70 percent may indicate that many targeted compounds may be present in greater concentrations than reported. Surrogate recovery rates ( median percent recoveries ranging from 78.0 to 86.7 percent) and the mean percent recoveries (ranging from 77.5 to 87.4 percent) are listed in table 6 . 
Table 5. Summary of replicate water-quality data for nutrients, major ions, pesticides and pesticide degradates, Cedar Rapids, lowa, calendar years 1999-2005.

[mg/L, milligrams per liter; $\mu \mathrm{g} / \mathrm{L}$, micrograms per liter]

\begin{tabular}{|c|c|c|c|c|c|}
\hline \multirow{2}{*}{$\begin{array}{c}\text { Water-quality } \\
\text { constituent }\end{array}$} & \multirow{2}{*}{$\begin{array}{c}\text { Number of } \\
\text { replicate } \\
\text { samples }\end{array}$} & \multicolumn{4}{|c|}{ Relative percent difference } \\
\hline & & Minimum & Maximum & Mean & Median \\
\hline \multicolumn{6}{|c|}{ Nutrients } \\
\hline Ammonia (mg/L as N) & 26 & 0 & 37.1 & 3.6 & 0.5 \\
\hline Nitrite + nitrate $(\mathrm{mg} / \mathrm{L}$ as $\mathrm{N})$ & 26 & 0 & 18.5 & 3.3 & 1.5 \\
\hline Nitrite (mg/L as N) & 26 & 0 & 10.5 & 6.9 & 0 \\
\hline Orthophosphate (mg/L as P) & 26 & 0 & 78.2 & 14.8 & 6.2 \\
\hline Organic carbon (mg/L) & 24 & 0 & 28 & 4.7 & 3 \\
\hline \multicolumn{6}{|c|}{ Major ions } \\
\hline Boron $(\mu \mathrm{g} / \mathrm{L})$ & 25 & 0.40 & 17.7 & 6.0 & 5.3 \\
\hline Bromide (mg/L) & 24 & 0 & 69.4 & 13.2 & 8.5 \\
\hline Calcium (mg/L) & 25 & .13 & 5.1 & 1.7 & 1.4 \\
\hline Chloride (mg/L) & 25 & .16 & 10.2 & 1.7 & 1 \\
\hline Fluoride (mg/L) & 25 & 0 & 61.3 & 6.8 & 2.4 \\
\hline $\operatorname{Iron}(\mu \mathrm{g} / \mathrm{L})$ & 25 & 0 & 40.1 & 7.7 & 2.8 \\
\hline Magnesium (mg/L) & 25 & .12 & 12 & 1.7 & 1.2 \\
\hline Manganese $(\mu \mathrm{g} / \mathrm{L})$ & 25 & .03 & 66.6 & 4.8 & .87 \\
\hline Potassium (mg/L) & 25 & 0 & 12.3 & 3 & 2.2 \\
\hline Silica (mg/L) & 25 & 0 & 6 & .9 & .46 \\
\hline Sodium (mg/L) & 25 & .22 & 34.3 & 4 & 2.2 \\
\hline Sulfate (mg/L) & 25 & .06 & 10.7 & 1.1 & .57 \\
\hline Residue on evaporation (mg/L) & 25 & 0 & 14.3 & 2 & 1 \\
\hline \multicolumn{6}{|c|}{ Pesticides } \\
\hline Acetochlor $(\mu \mathrm{g} / \mathrm{L})$ & 26 & 0 & 240 & 14.7 & 0 \\
\hline Alachlor $(\mu \mathrm{g} / \mathrm{L})$ & 26 & 0 & 0 & 0 & 0 \\
\hline Ametryn $(\mu \mathrm{g} / \mathrm{L})$ & 26 & 0 & 93.4 & 4.3 & 0 \\
\hline Atrazine $(\mu \mathrm{g} / \mathrm{L})$ & 26 & 0 & 42 & 7.8 & 4.6 \\
\hline Bromacil ( $\mu \mathrm{g} / \mathrm{L})$ & 26 & 0 & 0 & 0 & 0 \\
\hline Cyanazine $(\mu \mathrm{g} / \mathrm{L})$ & 26 & 0 & 0 & 0 & 0 \\
\hline Cycloate ( $\mu \mathrm{g} / \mathrm{L})$ & 26 & 0 & 0 & 0 & 0 \\
\hline Diphenamid $(\mu \mathrm{g} / \mathrm{L})$ & 26 & 0 & 0 & 0 & 0 \\
\hline Metolachlor $(\mu \mathrm{g} / \mathrm{L})$ & 26 & 0 & 58.5 & 8.2 & 5.3 \\
\hline Metribuzin $(\mu \mathrm{g} / \mathrm{L})$ & 26 & 0 & 58.4 & 3.1 & 0 \\
\hline Prometon $(\mu \mathrm{g} / \mathrm{L})$ & 26 & 0 & 34.6 & 4.7 & 0 \\
\hline Propazine $(\mu \mathrm{g} / \mathrm{L})$ & 26 & 0 & 21.4 & 5.4 & 0 \\
\hline Simazine $(\mu \mathrm{g} / \mathrm{L})$ & 26 & 0 & 22.9 & .94 & 0 \\
\hline Terbacil $(\mu \mathrm{g} / \mathrm{L})$ & 26 & 0 & 0 & 0 & 0 \\
\hline Trifluralin $(\mu \mathrm{g} / \mathrm{L})$ & 26 & 0 & 0 & 0 & 0 \\
\hline $\mathrm{CIAT}^{1}(\mu \mathrm{g} / \mathrm{L})$ & 26 & 0 & 22.3 & 7.7 & 5.5 \\
\hline $\mathrm{CEAT}^{1}(\mu \mathrm{g} / \mathrm{L})$ & 26 & 0 & 46.2 & 6.5 & 0 \\
\hline
\end{tabular}

${ }^{1}$ Atrazine degradates: 2-Chloro-4-amino-6-isopropyl-amino-striazine (CIAT) and 2-Chloro-4-ethylamino-6-amino-s-triazine (CEAT). 
Table 6. Surrogate pesticide data for samples from groundwater and surface-water sampling sites with minimum, maximum, median, and mean percent recovery, Cedar Rapids, lowa, calendar years 1999-2005.

\begin{tabular}{|c|c|c|c|c|}
\hline Site name & Minimum & Maximum & Median & Mean \\
\hline \multicolumn{5}{|c|}{ alpha-HCH-d6 surrogate (percent recovery) } \\
\hline CRM-26 & 59.7 & 101.2 & 84.5 & 83.7 \\
\hline CRM-22 & 27.3 & 150.9 & 84.5 & 82.8 \\
\hline CRM-23 & 30.5 & 121.9 & 81.2 & 82.7 \\
\hline CRM-24 & 65.9 & 96.2 & 85.7 & 85.0 \\
\hline CRM-27 & 59.4 & 106.1 & 85.1 & 84.8 \\
\hline CRM-25 & 62.7 & 108.0 & 84.3 & 83.3 \\
\hline Cedar River & 44.1 & 107.4 & 82.2 & 84.1 \\
\hline Wetland pond & 55.0 & 98.4 & 87.2 & 80.0 \\
\hline \multicolumn{5}{|c|}{ Diazinon-d10 surrogate (percent recovery) } \\
\hline CRM-26 & 62.4 & 113.3 & 83.6 & 83.2 \\
\hline CRM-22 & 29.8 & 151.2 & 80.4 & 78.0 \\
\hline CRM-23 & 27.0 & 147.0 & 78.0 & 78.5 \\
\hline CRM-24 & 60.6 & 89.5 & 78.9 & 77.5 \\
\hline CRM-27 & 67.3 & 128.2 & 86.7 & 87.4 \\
\hline CRM-25 & 62.0 & 117.6 & 82.9 & 79.9 \\
\hline Cedar River & 31.6 & 123.4 & 81.4 & 81.0 \\
\hline Wetland pond & 71.2 & 110.0 & 87.9 & 90.3 \\
\hline
\end{tabular}

\section{Water-Quality Data from Cedar River and Cedar Rapids Well Fields}

The results of the water-quality samples collected from January 1999 through December 2005 are listed and summarized in tables 7 to 20 at the back of this report. Data compiled are from the Cedar River, water-quality monitoring of the wells from quarterly monitoring, evaluation of groundwater and surface-water interaction studies, and characterization of water quality in shallow groundwater near a wetland area in the Seminole Well Field.

Water-quality data from water samples were used to assess the alluvial aquifer and the Cedar River. The Cedar River is the main affect on water quality in the alluvial aquifer because of induced infiltration from the river because of pumping (Schulmeyer and Schnoebelen, 1998; Boyd, 1999; Turco and Buchmiller, 2004). Agricultural chemicals (nutrients and pesticides) are of concern because of the predominance of agricultural land use ( 90 percent and greater) in the Cedar River Basin. A 12-mile (mi) reach of the Cedar River upstream from Cedar Rapids, Iowa, is identified on the Total Maximum Daily Load (TMDL) list for nitrate impairment (Iowa Department of Natural Resources, 1994; U.S. Environmental Protection Agency, 2003). Water-quality data sampling efforts have concentrated on nutrients and pesticides with selected major ions and physical parameters.

\section{Physical Parameters, Major lons, and Nutrients}

Physical parameters were measured at each sampling site whenever a sample for water quality was collected. Physical parameters include air pressure, dissolved oxygen, $\mathrm{pH}$ (field value and laboratory value), specific conductance, water temperature, air temperature and alkalinity. Summary statistics for physical parameters of water from all sites and from individual sites are shown in tables 7 and 8 , respectively.

Major ion data compiled includes calcium, magnesium, potassium, sodium, bromide, chloride, fluoride, silica, sulfate, boron, iron, and manganese. Major ion data are required for characterization of the water chemistry and geochemical modeling. Major ion summary statistics for all sites are shown in table 9. Major ion data for groundwater samples from the alluvium versus surface-water samples from the river are summarized in table 10 .

Most of the nutrient data include ammonia, nitrate plus nitrite, nitrite, and orthophosphate. In addition, dissolved organic carbon is summarized with nutrient data. Five samples were analyzed for ammonia plus organic nitrogen (filtered and unfiltered) and phosphorus (filtered and unfiltered). Nutrient summary statistics for water from all sites are shown in table 11. Nutrient data for groundwater samples from the alluvium versus surface-water samples from the river are summarized in table 12. Summary statistics for water from each individual site sampled for major ions, nutrients, and organic carbon are listed in table 13.

\section{Pesticides}

Pesticides are used to control unwanted vegetation, insects, and other pests in agricultural and urban areas. Typically, large amounts (thousands of pounds per year) of common herbicides are applied during the growing season in Iowa and in the Cedar River Basin to corn and soybean crops (Schnoebelen and others, 2003). Triazine (atrazine and cyanazine) and chloroacetanilide (acetochlor and metolachlor) herbicides generally are the most extensively used herbicides in eastern Iowa. Insecticides are detected less often in water most likely because of their lower use relative to herbicides, short persistence, and selected application during periods of reduced runoff (Schnoebelen and others, 2003). Pesticide degradates are formed when a parent pesticide compound breaks down or degrades. Pesticide degradates often have been detected at higher concentrations than their parent compounds (Kolpin and others, 2000, Kolpin and others, 2004, and Schnoebelen and others, 2003). The pesticide degradates of atrazine: 2-Chloro-4-ethylamino-6-amino-s-triazine (CEAT) and 2-Chloro-4-amino-6-isopropyl-amino-striazine (CIAT) were the only two degradates regularly analyzed. These two degradates (CEAT and CIAT) are included in all tables listing the pesticides. Names of pesticide and pesticide degradates sampled for during the study period and their uses are listed in 
table 14. Pesticides and pesticide degradates that were tested for but not detected are listed in tables 15 and 16, respectively.

Pesticide detections for water from all sites are shown in table 17. Pesticide detections for groundwater samples from the alluvium and surface-water samples from the river are shown in table 18. Pesticide detections by individual site are listed in table 19. Seven sites (CRM 22, CRM 23, Seminole 17, Ranney 1, Ranney 4, Waterworks Plant, and Cedar River at Edgewood Road) were sampled for pesticide degradates only; pesticide degradates detected in water from these seven sites are listed in table 20.

\section{References Cited}

Boyd, R.A., 1998, Characterizing groundwater flow in the municipal well fields of Cedar Rapids, Iowa, with selected environmental tracers: Journal of the American Water Resources Association, vol. 34, no. 3, p. 507-518.

Boyd, R.A., 1999, Herbicides and herbicide degradates in shallow ground water and the Cedar River near a municipal well field, Cedar Rapids, Iowa: The Science of the Total Environment vol. 248 p. 241-253.

Boyd, R.A., Kuzniar, R.L., and Schulmeyer, P.M., 1999, Selected hydrologic data from the Cedar Rapids area, Linn County, Iowa, April 1996 through March 1999: U.S. Geological Survey Open File Report 99-461, 214 p.

Hansen, R.E., 1970, Geology and groundwater resources of Linn County, Iowa: Iowa Geological Survey, Water-Supply Bulletin no. 10, 66 p.

Iowa Department of Natural Resources, 1994, Water-quality in Iowa during 1992 and 1993: Iowa Environmental Protection Division, Water Resources Section 305(b) Report, 226 p.

Kolpin, D.W., Thurman, E.M., and Linhart, S.M., 2000, Finding minimal herbicide concentrations in ground water? Try looking for degradates: The Science of the Total Environment, vol. 248, p. 115-122.

Kolpin, D.W., Schnoebelen, D.J., and Thurman, E.M., 2004, Degradates provide insight to spatial and temporal trends of herbicides in ground water: Ground Water, vol. 42, no. 4, p. 601-608.

Mueller, D.K., Martin, J.D., and Lopes, T.J., 1997, Qualitycontrol design for surface-water sampling in the National Water-Quality Assessment Program: U.S. Geological Survey Open-File Report 97-223, 17 p.

Nalley, G.M., Gorman, J.G., Goodrich, R.D., Littin, G.R., Linhart, S.M., and Miller,V.E., 2004, Water resources data, Iowa, Water Year 2003: U.S. Geological Survey Water-Data Report IA-03-01, $473 \mathrm{p}$.
Nalley, G.M., Gorman, J.G., Goodrich, R.D., Littin, G.R., Linhart, S.M., Miller,V.E., and Housel, K.S., 2005, Water resources data, Iowa, Water Year 2004: U.S. Geological Survey Water-Data Report IA-04-01, 503 p.

Nalley, G.M., Gorman, J.G., Goodrich, R.D., Littin, G.R., Linhart, S.M., Miller, V.E., and Housel, K.S., 2006, Water resources data, Iowa, Water Year 2005: U.S. Geological Survey Water-Data Report IA-05-01, 534 p.

National Oceanic and Atmospheric Administration, 1999, Climatological data, Iowa, annual summary: Acheville, North Carolina National climatic Data Center, v. 109. no. 13, 35 p.

Oblinger-Childress, C.J., Foreman,W.T., Connor, B.F., and Maloney, T.J., 1999, New reporting procedures based on long-term method detection levels and some considerations for interpretations of water-quality data provided by the U.S. Geological Survey National Water Quality Laboratory, U.S. Geological Survey Open-File Report 99-193, 19 p.

Schnoebelen, D.J., Kalkhoff, S.J., Becher, K.D., and Thurman, E.M., 2003, Water-quality assessment of the Iowa Basins: Selected pesticides and pesticide degradates in streams, 1996-98: U.S. Geological Survey Water Resources Investigations Report 03-4075, 62 p.

Schnoebelen, D.J., and Schulmeyer, P.M., 1996, Selected hydrogeologic data from the Cedar Rapids area, Benton and Linn Counties, Iowa, October 1992 through March 1996: U.S. Geological Survey Open File Report 96-471, 172 p.

Schulmeyer, P.M., 1995, Effect of the Cedar River on the quality of ground-water supply for Cedar Rapids, Iowa: U.S. Geological Survey Water-Resources Investigations Report 94-4211, $68 \mathrm{p}$.

Schulmeyer, P.M., and Schnoebelen, D.J., 1998, Hydrogeology and water quality in the Cedar Rapids area, Iowa, 1992 96: U.S. Geological Survey Water-Resources Investigations Report 97-4261, $77 \mathrm{p}$.

Turco, M.J., and Buchmiller, R.C., 2004, Simulation of ground-water flow in the Cedar River alluvial aquifer flow system, Cedar Rapids, Iowa: U.S. Geological Survey Scientific Investigations Report 2004-5130

U.S. Census Bureau, 2000, State and county quickfacts, Linn County, Cedar Rapids, Iowa: accessed August, 2007 at http://quickfacts.census.gov/qfd/states/19/1912000.html

U.S. Environmental Protection Agency, 2003, National impaired water list by State, Cedar River, Iowa: accessed January 2003, at http://iaspub.epa.gov/waters10/attains_ nation_cy.control?p_report_type $=T \# i m p \_w a t e r$ by_state 
U.S. Geological Survey, 2006, and other chapters, variously dated, National field manual for the collection of waterquality data: U.S. Geological Survey Techniques of WaterResources Investigations, book 9, chaps. A1-A9, accessed April 2007 at http://pubs.water.usgs.gov/twri9A

Wahl, K.D., and Bunker, B.J., 1986, Hydrology and carbonate aquifers in southwestern Linn County and adjacent parts of Benton, Iowa, and Johnson Counties, Iowa: Iowa Geological Survey, Water Supply Bulletin no. 15, 56 p.

Wershaw, R.L., Fishman, M.J., Grabbe, R.R., and Lowe, L.E., eds., 1987, Methods for the determination of organic substances in water and fluvial sediments: U.S. Geological Survey Techniques of Water-Resources Investigations, book 5, chap. A3, 80 p. 

Tables 7-20 
Table 7. Physical parameters, summary statistics of groundwater and surface-water quality data combined, Cedar Rapids, lowa, calendar years 1999-2005.

[mm Hg, millimeters mercury; mg/L milligrams per liter; std, standard; w, water; u, unfiltered; $\mu \mathrm{S} / \mathrm{cm}$, microseimens per centimeter; deg C, degrees Celsius; \pm , plus or minus; \% percent]

\begin{tabular}{|c|c|c|c|c|c|c|c|c|c|}
\hline & $\begin{array}{c}\text { Air pressure } \\
(00025) \\
(\mathrm{mm} \mathrm{Hg})\end{array}$ & $\begin{array}{c}\text { Dissolved } \\
\text { oxygen }^{1} \\
(00300) \\
\text { (mg/L) }\end{array}$ & $\begin{array}{c}\text { pH, field }{ }^{2} \\
\text { (00400) } \\
\text { (std units) }\end{array}$ & $\begin{array}{c}\text { pH, wu, lab } \\
\text { (00403) } \\
\text { (std units) }\end{array}$ & 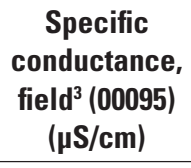 & $\begin{array}{c}\text { Specific } \\
\text { conductance, } \\
\text { lab }(90095) \\
(\mu S / \mathrm{cm})\end{array}$ & $\begin{array}{c}\text { Water } \\
\text { temperature } \\
\text { 00010) } \\
(\operatorname{deg} C)\end{array}$ & $\begin{array}{c}\text { Air } \\
\text { temperature } \\
(00020) \\
(\operatorname{deg} C)\end{array}$ & $\begin{array}{c}\text { Alkalinity } \\
(39086) \\
(\mathrm{mg} / \mathrm{L} \text { as } \\
\left.\mathrm{CaCO}_{3}\right)\end{array}$ \\
\hline $\begin{array}{c}\text { Number of } \\
\text { samples }\end{array}$ & 183 & 310 & 313 & 297 & 318 & 298 & 319 & 180 & 240 \\
\hline Maximum & 764 & 18.4 & 9.2 & 8.4 & 1,700 & 1,506 & 28.1 & 41.1 & 954 \\
\hline Minimum & 724 & 0 & 6.3 & 6.6 & 226 & 359 & 0 & -17.4 & 55 \\
\hline Average & 746 & 3 & 7 & 8 & 552 & 549 & 13.9 & 15.2 & 212 \\
\hline
\end{tabular}

${ }^{1}$ Instrument accuracy for 0 to $20 \mathrm{mg} / \mathrm{L}$ was $\pm 2 \%$ of reading or $\pm 0.2 \mathrm{mg} / \mathrm{L}$, whichever was greater.

${ }^{2}$ Instrument accuracy was \pm 0.2 units.

${ }^{3}$ Instrument accuracy was $\pm 0.5 \%$ of reading $+0.001 \mu \mathrm{S} / \mathrm{cm}$.

Table 8. Physical parameters, summary statistics of groundwater and surface-water quality data by site, Cedar Rapids, lowa, calendar years 1999-2005.

[mm Hg, millimeters mercury; mg/L milligrams per liter; std, standard; w, water; u, unfiltered; $\mu \mathrm{S} / \mathrm{cm}$, microseimens per centimeter; deg C, degrees Celsius; $<$, actual value is known to be less than value shown; --, no data]

\begin{tabular}{|c|c|c|c|c|c|}
\hline Site name & & $\begin{array}{c}\text { Air pressure } \\
(00025) \\
(\mathrm{mm} \mathrm{Hg})\end{array}$ & $\begin{array}{c}\text { Dissolved oxygen } \\
(00300) \\
(\mathrm{mg} / \mathrm{L})\end{array}$ & $\begin{array}{c}\mathrm{pH} \\
(00400) \\
\text { (std units) }\end{array}$ & $\begin{array}{c}\text { pH, wu, lab } \\
\text { (00403) } \\
\text { (std units) }\end{array}$ \\
\hline \multirow[t]{4}{*}{ 1993USGS CRM-1 } & Number of samples & 12 & 15 & 17 & 17 \\
\hline & Maximum & 762 & .3 & 7.6 & 7.7 \\
\hline & Minimum & 731 & 0 & 6.8 & 7.2 \\
\hline & Average & 748 & .1 & 7.2 & 7.4 \\
\hline \multirow[t]{4}{*}{ 1993USGS CRM-2 } & Number of samples & 13 & 17 & 17 & 16 \\
\hline & Maximum & 759 & .5 & 7.9 & 8 \\
\hline & Minimum & 731 & $<.1$ & 6.8 & 7.4 \\
\hline & Average & 747 & .2 & 7.3 & 7.7 \\
\hline \multirow[t]{4}{*}{ 1993USGS CRM-4 } & Number of samples & 12 & 17 & 17 & 17 \\
\hline & Maximum & 760 & 4 & 7.7 & 7.9 \\
\hline & Minimum & 731 & 0 & 6.6 & 7.2 \\
\hline & Average & 746 & .4 & 7.2 & 7.5 \\
\hline \multirow[t]{4}{*}{ 1998USGS CRM-22 } & Number of samples & 18 & 31 & 31 & 31 \\
\hline & Maximum & 764 & 11.4 & 7.8 & 8.1 \\
\hline & Minimum & 732 & 0 & 6.5 & 7 \\
\hline & Average & 745 & 1.2 & 7.4 & 7.6 \\
\hline
\end{tabular}


Table 8. Physical parameters, summary statistics of groundwater and surface-water quality data by site, Cedar Rapids, lowa, calendar years 1999-2005.-Continued

[mm Hg, millimeters mercury; mg/L milligrams per liter; std, standard; w, water; u, unfiltered; $\mu \mathrm{S} / \mathrm{cm}$, microseimens per centimeter; deg $\mathrm{C}$, degrees Celsius; <, actual value is known to be less than value shown; --, no data]

\begin{tabular}{|c|c|c|c|c|c|}
\hline Site name & & $\begin{array}{c}\text { Air pressure } \\
(00025) \\
(\mathrm{mm} \mathrm{Hg})\end{array}$ & $\begin{array}{c}\text { Dissolved oxygen } \\
(00300) \\
(\mathrm{mg} / \mathrm{L})\end{array}$ & $\begin{array}{c}\text { pH } \\
(00400) \\
\text { (std units) }\end{array}$ & $\begin{array}{c}\text { pH, wu, lab } \\
\text { (00403) } \\
\text { (std units) }\end{array}$ \\
\hline \multirow[t]{4}{*}{ 1998USGS CRM-23 } & Number of samples & 15 & 28 & 28 & 28 \\
\hline & Maximum & 756 & 9.6 & 7.5 & 7.9 \\
\hline & Minimum & 733 & 0 & 6.6 & 6.6 \\
\hline & Average & 745 & .9 & 7 & 7.3 \\
\hline \multirow[t]{4}{*}{ 1998USGS CRM-25 } & Number of samples & 14 & 21 & 21 & 20 \\
\hline & Maximum & 764 & 9.6 & 7.1 & 7.4 \\
\hline & Minimum & 732 & .1 & 6.3 & 6.9 \\
\hline & Average & 746 & 6.1 & 6.7 & 7.1 \\
\hline \multirow[t]{4}{*}{ 1998USGS CRM-26 } & Number of samples & 13 & 19 & 18 & 20 \\
\hline & Maximum & 764 & .6 & 7.4 & 7.8 \\
\hline & Minimum & 735 & $<.1$ & 6.7 & 7.2 \\
\hline & Average & 747 & .2 & 7.1 & 7.5 \\
\hline \multirow[t]{4}{*}{ 1998USGS CRM-27 } & Number of samples & 14 & 20 & 19 & 20 \\
\hline & Maximum & 764 & 4.7 & 7.2 & 7.7 \\
\hline & Minimum & 731 & 0 & 6.6 & 7.1 \\
\hline & Average & 747 & .4 & 6.9 & 7.3 \\
\hline \multirow[t]{4}{*}{ 1990Seminole 14} & Number of samples & 1 & 6 & 6 & 4 \\
\hline & Maximum & 737 & 3.5 & 7.3 & 7.5 \\
\hline & Minimum & 737 & .4 & 7.1 & 7.3 \\
\hline & Average & 737 & 1.5 & 7.2 & 7.4 \\
\hline \multirow[t]{4}{*}{ Seminole 17} & Number of samples & 5 & 11 & 11 & 11 \\
\hline & Maximum & 749 & 3.8 & 7.5 & 7.7 \\
\hline & Minimum & 737 & .1 & 6.8 & 7.1 \\
\hline & Average & 744 & 1.5 & 7.2 & 7.5 \\
\hline \multirow[t]{4}{*}{ 1991Seminole 18} & Number of samples & 3 & 5 & 5 & 5 \\
\hline & Maximum & 749 & 6 & 7.5 & 7.7 \\
\hline & Minimum & 744 & .2 & 7.2 & 6.7 \\
\hline & Average & 746 & 1.7 & 7.4 & 7.3 \\
\hline \multirow[t]{4}{*}{ Seminole Ranney 1} & Number of samples & 4 & 10 & 10 & 9 \\
\hline & Maximum & 747 & 8.1 & 7.6 & 7.7 \\
\hline & Minimum & 743 & .3 & 7 & 7.3 \\
\hline & Average & 744 & 2.1 & 7.3 & 7.5 \\
\hline
\end{tabular}


Table 8. Physical parameters, summary statistics of groundwater and surface-water quality data by site, Cedar Rapids, lowa, calendar years 1999-2005._Continued

[mm Hg, millimeters mercury; mg/L milligrams per liter; std, standard; w, water; u, unfiltered; $\mu \mathrm{S} / \mathrm{cm}$, microseimens per centimeter; deg C, degrees Celsius; < actual value is known to be less than value shown; --, no data]

\begin{tabular}{|c|c|c|c|c|c|}
\hline Site name & & $\begin{array}{c}\text { Air pressure } \\
(00025) \\
(\mathrm{mm} \mathrm{Hg})\end{array}$ & $\begin{array}{c}\text { Dissolved oxygen } \\
(00300) \\
(\mathrm{mg} / \mathrm{L})\end{array}$ & $\begin{array}{c}\text { pH } \\
(00400) \\
\text { (std units) }\end{array}$ & $\begin{array}{c}\text { pH, wu, lab } \\
\text { (00403) } \\
\text { (std units) }\end{array}$ \\
\hline \multirow[t]{4}{*}{ Seminole Ranney 2} & Number of samples & 2 & 9 & 9 & 9 \\
\hline & Maximum & 747 & 5.1 & 7.7 & 7.8 \\
\hline & Minimum & 742 & .4 & 7.2 & 7.3 \\
\hline & Average & 745 & 1.8 & 7 & 8 \\
\hline \multirow[t]{4}{*}{ Edgewood Ranney } & Number of samples & 4 & 12 & 13 & 12 \\
\hline & Maximum & 758 & 3.8 & 7.5 & 7.8 \\
\hline & Minimum & 744 & .2 & 7 & 7.2 \\
\hline & Average & 750 & .8 & 7.3 & 7.5 \\
\hline \multirow[t]{4}{*}{ Seminole Ranney 4} & Number of samples & 5 & 12 & 13 & 11 \\
\hline & Maximum & 758 & 4.2 & 7.6 & 8.1 \\
\hline & Minimum & 743 & .2 & 7.1 & 7.2 \\
\hline & Average & 747 & 1.8 & 7.3 & 7.5 \\
\hline \multirow[t]{4}{*}{ Cedar Rapids Waterworks } & Number of samples & 14 & 28 & 31 & 28 \\
\hline & Maximum & 761 & 2.5 & 7.8 & 7.7 \\
\hline & Minimum & 728 & 0 & 6.8 & 7.1 \\
\hline & Average & 746 & .7 & 7.2 & 7.4 \\
\hline \multirow[t]{4}{*}{ Cedar River at Edgewood Rd. } & Number of samples & 29 & 41 & 41 & 33 \\
\hline & Maximum & 764 & 18.4 & 9.2 & 8.4 \\
\hline & Minimum & 724 & 7.5 & 7.4 & 6.7 \\
\hline & Average & 745 & 11.6 & 8.2 & 8 \\
\hline \multirow[t]{4}{*}{ Wetland Pond at CRM-27 } & Number of samples & 5 & 6 & 6 & 5 \\
\hline & Maximum & 764 & 17.6 & 8.9 & 8.1 \\
\hline & Minimum & 732 & 4.5 & 7.1 & 7.5 \\
\hline & Average & 745 & 11 & 8.1 & 7.8 \\
\hline
\end{tabular}


Table 8. Physical parameters, summary statistics of groundwater and surface-water quality data by site, Cedar Rapids, lowa, calendar years 1999-2005.-Continued

$[\mathrm{mm} \mathrm{Hg}$, millimeters mercury; mg/L milligrams per liter; std, standard; w, water; u, unfiltered; $\mu \mathrm{S} / \mathrm{cm}$, microseimens per centimeter; deg C, degrees Celsius; $<$, actual value is known to be less than value shown; --, no data]

\begin{tabular}{|c|c|c|c|c|c|c|}
\hline Site name & & $\begin{array}{c}\text { Specific } \\
\text { conductance } \\
(00095) \\
(\mu S / \mathrm{cm})\end{array}$ & $\begin{array}{c}\text { Specific } \\
\text { conductance, } \\
\text { wu (90095) } \\
(\mu \mathrm{S} / \mathrm{cm})\end{array}$ & $\begin{array}{c}\text { Water } \\
\text { temperature } \\
(00010) \\
(\operatorname{deg} C)\end{array}$ & $\begin{array}{c}\text { Air } \\
\text { temperature } \\
(00020) \\
(\operatorname{deg} C)\end{array}$ & $\begin{array}{c}\text { Alkalinity } \\
\text { (39086) } \\
(\mathrm{mg} / \mathrm{L} \text { as } \\
\left.\mathrm{CaCO}_{3}\right)\end{array}$ \\
\hline \multirow[t]{4}{*}{${ }^{1} 1993$ USGS CRM-1 } & Number of samples & 17 & 17 & 17 & 16 & 16 \\
\hline & Maximum & 1,700 & 1,506 & 21 & 27.1 & 954 \\
\hline & Minimum & 448 & 438 & 3.5 & -1 & 143 \\
\hline & Average & 647 & 614 & 11.5 & 14.3 & 284 \\
\hline \multirow[t]{4}{*}{ 1993USGS CRM-2 } & Number of samples & 17 & 16 & 17 & 15 & 16 \\
\hline & Maximum & 772 & 775 & 24.5 & 28.5 & 369 \\
\hline & Minimum & 430 & 434 & 9 & -1.4 & 169 \\
\hline & Average & 553 & 554 & 13.8 & 14.4 & 220 \\
\hline \multirow[t]{4}{*}{ 1993USGS CRM-4 } & Number of samples & 17 & 17 & 17 & 16 & 16 \\
\hline & Maximum & 674 & 691 & 24 & 33.7 & 276 \\
\hline & Minimum & 433 & 435 & 9 & -1 & 153 \\
\hline & Average & 564 & 561 & 13.6 & 16.9 & 211.4 \\
\hline \multirow[t]{4}{*}{ 1998USGS CRM-22 } & Number of samples & 32 & 31 & 32 & 17 & 22 \\
\hline & Maximum & 715 & 697 & 26 & 29 & 263 \\
\hline & Minimum & 390 & 365 & .3 & -4.1 & 123 \\
\hline & Average & 537 & 523 & 14.1 & 16.5 & 198 \\
\hline \multirow[t]{4}{*}{ 1998USGS CRM-23 } & Number of samples & 29 & 29 & 30 & 15 & 22 \\
\hline & Maximum & 644 & 659 & 25 & 30 & 284 \\
\hline & Minimum & 370 & 379 & 3.4 & -4.1 & 172 \\
\hline & Average & 521 & 522 & 14.2 & 14.6 & 210 \\
\hline \multirow[t]{4}{*}{ 1998USGS CRM-25 } & Number of samples & 21 & 20 & 21 & 15 & 16 \\
\hline & Maximum & 684 & 678 & 22 & 41.1 & 219 \\
\hline & Minimum & 426 & 425 & 8.5 & -1 & 132 \\
\hline & Average & 504 & 509 & 14 & 16.6 & 170 \\
\hline \multirow[t]{4}{*}{ 1998USGS CRM-26 } & Number of samples & 19 & 20 & 19 & 15 & 14 \\
\hline & Maximum & 747 & 739 & 17 & 29 & 362 \\
\hline & Minimum & 475 & 487 & 5 & -1.3 & 164 \\
\hline & Average & 581 & 581 & 12.9 & 15.8 & 234 \\
\hline \multirow[t]{4}{*}{ 1998USGS CRM-27 } & Number of samples & 20 & 20 & 20 & 16 & 16 \\
\hline & Maximum & 693 & 686 & 19 & 40.5 & 304 \\
\hline & Minimum & 541 & 545 & 8 & -.7 & 200 \\
\hline & Average & 618 & 621 & 13.3 & 17.3 & 260.7 \\
\hline
\end{tabular}


Table 8. Physical parameters, summary statistics of groundwater and surface-water quality data by site, Cedar Rapids, lowa, calendar years 1999-2005.-Continued

[mm Hg, millimeters mercury; mg/L milligrams per liter; std, standard; w, water; $\mathrm{u}$, unfiltered; $\mu \mathrm{S} / \mathrm{cm}$, microseimens per centimeter; deg C, degrees Celsius; $<$, actual value is known to be less than value shown; --, no data]

\begin{tabular}{|c|c|c|c|c|c|c|}
\hline Site name & & $\begin{array}{c}\text { Specific } \\
\text { conductance } \\
(00095) \\
(\mu \mathrm{S} / \mathrm{cm})\end{array}$ & $\begin{array}{c}\text { Specific } \\
\text { conductance, } \\
\text { wu (90095) } \\
(\mu \mathrm{S} / \mathrm{cm})\end{array}$ & $\begin{array}{c}\text { Water } \\
\text { temperature } \\
(00010) \\
(\operatorname{deg} C)\end{array}$ & $\begin{array}{c}\text { Air } \\
\text { temperature } \\
(00020) \\
(\operatorname{deg} \mathrm{C})\end{array}$ & $\begin{array}{c}\text { Alkalinity } \\
\text { (39086) } \\
\text { (mg/L as } \\
\text { CaCO }_{3} \text { ) }\end{array}$ \\
\hline \multirow[t]{4}{*}{ 1990Seminole 14} & Number of samples & 6 & 4 & 6 & -- & 2 \\
\hline & Maximum & 598 & 575 & 17.3 & -- & 226 \\
\hline & Minimum & 498 & 481 & 9.8 & -- & 183 \\
\hline & Average & 565 & 533 & 12.9 & -- & 205 \\
\hline \multirow[t]{4}{*}{ Seminole 17} & Number of samples & 11 & 11 & 11 & 2 & 8 \\
\hline & Maximum & 601 & 578 & 19.4 & 28.4 & 221 \\
\hline & Minimum & 490 & 417 & 5.2 & -7.9 & 173 \\
\hline & Average & 544 & 512 & 13.1 & 10.3 & 202.3 \\
\hline \multirow[t]{4}{*}{ 1991Seminole 18} & Number of samples & 5 & 5 & 5 & 2 & 5 \\
\hline & Maximum & 585 & 560 & 18.2 & 28.4 & 213 \\
\hline & Minimum & 497 & 491 & 5.7 & -9.7 & 196 \\
\hline & Average & 551 & 535 & 11.3 & 9.4 & 207 \\
\hline \multirow[t]{4}{*}{ Seminole Ranney 1} & Number of samples & 10 & 9 & 10 & 1 & 7 \\
\hline & Maximum & 623 & 618 & 24.2 & -16.7 & 219 \\
\hline & Minimum & 444 & 424 & 4.6 & -16.7 & 135 \\
\hline & Average & 551 & 533 & 13.8 & -16.7 & 195 \\
\hline \multirow[t]{4}{*}{ Seminole Ranney 2} & Number of samples & 9 & 9 & 9 & 2 & 8 \\
\hline & Maximum & 586 & 578 & 21.2 & 27.2 & 210 \\
\hline & Minimum & 470 & 449 & 3.4 & -14.5 & 164 \\
\hline & Average & 535 & 512 & 13.2 & 6.4 & 189 \\
\hline \multirow[t]{4}{*}{ Edgewood Ranney } & Number of samples & 13 & 11 & 13 & 2 & 9 \\
\hline & Maximum & 607 & 579 & 23.1 & 28 & 228 \\
\hline & Minimum & 483 & 468 & 7.3 & -14.5 & 182 \\
\hline & Average & 560 & 534 & 15.1 & 6.8 & 205 \\
\hline \multirow[t]{4}{*}{ Seminole Ranney 4} & Number of samples & 13 & 11 & 13 & 1 & 7 \\
\hline & Maximum & 734 & 623 & 28.1 & -8.6 & 238 \\
\hline & Minimum & 478 & 449 & 6.2 & -8.6 & 176 \\
\hline & Average & 567 & 540 & 15.3 & -8.6 & 206 \\
\hline \multirow[t]{4}{*}{ Cedar Rapids Waterworks } & Number of samples & 31 & 28 & 31 & 19 & 23 \\
\hline & Maximum & 721 & 681 & 22 & 29.5 & 307 \\
\hline & Minimum & 284 & 471 & 7 & -17.4 & 172 \\
\hline & Average & 562 & 579 & 14.4 & 14.6 & 229 \\
\hline
\end{tabular}


Table 8. Physical parameters, summary statistics of groundwater and surface-water quality data by site, Cedar Rapids, lowa, calendar years 1999-2005.-Continued

[mm Hg, millimeters mercury; mg/L milligrams per liter; std, standard; w, water; u, unfiltered; $\mu \mathrm{S} / \mathrm{cm}$, microseimens per centimeter; deg C, degrees Celsius; <, actual value is known to be less than value shown; --, no data]

\begin{tabular}{|c|c|c|c|c|c|c|}
\hline Site name & & $\begin{array}{c}\text { Specific } \\
\text { conductance } \\
(00095) \\
(\mu S / \mathrm{cm})\end{array}$ & $\begin{array}{c}\text { Specific } \\
\text { conductance, } \\
\text { wu (90095) } \\
(\mu \mathrm{S} / \mathrm{cm})\end{array}$ & $\begin{array}{c}\text { Water } \\
\text { temperature } \\
(00010) \\
(\operatorname{deg} C)\end{array}$ & $\begin{array}{c}\text { Air } \\
\text { temperature } \\
(00020) \\
(\operatorname{deg} C)\end{array}$ & $\begin{array}{c}\text { Alkalinity } \\
\text { (39086) } \\
(\mathrm{mg} / \mathrm{L} \text { as } \\
\left.\mathrm{CaCO}_{3}\right)\end{array}$ \\
\hline \multirow[t]{4}{*}{ Cedar River at Edgewood Rd. } & Number of samples & 42 & 34 & 42 & 22 & 28 \\
\hline & Maximum & 724 & 660 & 27.1 & 31 & 243 \\
\hline & Minimum & 234 & 359 & 0 & 1 & 128 \\
\hline & Average & 508 & 517 & 14.6 & 17.1 & 184 \\
\hline \multirow[t]{4}{*}{ Wetland Pond at CRM-27 } & Number of samples & 6 & 5 & 6 & 4 & 5 \\
\hline & Maximum & 1,125 & 1,090 & 27 & 37.6 & 205 \\
\hline & Minimum & 226 & 463 & 3 & -1.2 & 55 \\
\hline & Average & 572 & 668 & 15.5 & 17.6 & 147 \\
\hline
\end{tabular}

\footnotetext{
${ }^{1}$ Maximum values largely represent concentrations from a sample likely affected by nearby industrial waste.
}

Table 9. Major ions, summary statistics of groundwater and surface-water quality data combined, Cedar Rapids, lowa, calendar years 1999-2005.

$[\mathrm{mg} / \mathrm{L}$, milligrams per liter; $<$, actual value is known to be less than value shown; $\mu \mathrm{g} / \mathrm{L}$, micrograms per liter]

\begin{tabular}{lcccc}
\hline \multicolumn{1}{c}{ Ion or trace element } & $\begin{array}{c}\text { Number of } \\
\text { samples }\end{array}$ & $\begin{array}{c}\text { Maximum } \\
\text { concentration' } \\
\text { (mg/L) }\end{array}$ & $\begin{array}{c}\text { Minimum } \\
\text { concentration } \\
\text { (mg/L) }\end{array}$ & $\begin{array}{c}\text { Average } \\
\text { (mg/L) }\end{array}$ \\
\hline Calcium & 297 & 203.3 & 25.9 & 72.5 \\
Magnesium & 297 & 61.8 & 11 & 20.8 \\
Potassium & 297 & 10.7 & 1.16 & 2.7 \\
Sodium & 297 & 26.4 & 5 & 11.8 \\
Bromide & 287 & .72 & $<.2$ & $<.2$ \\
Chloride & 299 & 42.9 & 8.56 & 24 \\
Fluoride & 297 & .4 & $<.1$ & .2 \\
Silica & 297 & 26.1 & $<.04$ & 11.9 \\
Sulfate & 297 & 539.9 & $<.1$ & 35.3 \\
Boron $^{2}$ & 292 & 133.4 & 12.2 & 37.7 \\
Iron $^{2}$ & 297 & 37,314 & $<10$ & 668 \\
Manganese $^{2}$ & 297 & 6,273 & $<3$ & 512 \\
\hline
\end{tabular}

${ }^{1}$ Maximum values largely represent concentrations from a groundwater sample likely affected by nearby industrial waste.

${ }^{2}$ Concentrations in ug/L. 
Table 10. Major ions, summary statistics of water-quality data for groundwater and surface-water sampling sites, Cedar Rapids, lowa, calendar years 1999-2005.

[mg/L, milligrams per liter; $\mu \mathrm{g} / \mathrm{L}$, micrograms per liter; $<$, actual value is known to be less than value shown; E, estimated]

\begin{tabular}{|c|c|c|c|c|c|}
\hline $\begin{array}{l}\text { Sample } \\
\text { medium }\end{array}$ & Ion or trace element & $\begin{array}{c}\text { Number of } \\
\text { samples }\end{array}$ & $\begin{array}{c}\text { Maximum } \\
\text { concentration } \\
(\mathrm{mg} / \mathrm{L})\end{array}$ & $\begin{array}{c}\text { Minimum } \\
\text { concentration } \\
\text { (mg/L) }\end{array}$ & $\begin{array}{c}\text { Average } \\
\text { (mg/L) }\end{array}$ \\
\hline \multirow[t]{12}{*}{ Groundwater $^{1}$} & Calcium & 259 & 203.3 & 27.7 & 72.8 \\
\hline & Magnesium & 259 & 61.8 & 11 & 20.7 \\
\hline & Potassium & 259 & 10.7 & 1.16 & 2.6 \\
\hline & Sodium & 259 & 26.4 & 5.8 & 11.9 \\
\hline & Bromide & 253 & .72 & $<.2$ & $<.2$ \\
\hline & Chloride & 259 & 42.9 & 10.9 & 24 \\
\hline & Fluoride & 259 & .4 & $<.1$ & .2 \\
\hline & Silica & 259 & 26.1 & $<.04$ & 12.4 \\
\hline & Sulfate & 259 & 83.7 & $<.1$ & 33.4 \\
\hline & Boron $^{2}$ & 256 & 133.4 & 12.2 & 37.7 \\
\hline & Iron $^{2}$ & 259 & 37,314 & $<10$ & 764 \\
\hline & Manganese $^{2}$ & 259 & 6,273 & $<3$ & 584 \\
\hline \multirow[t]{12}{*}{ Surface water } & Calcium & 38 & 166.3 & 25.9 & 70.1 \\
\hline & Magnesium & 38 & 295 & 15.1 & 21.7 \\
\hline & Potassium & 38 & 5.86 & 1.65 & 2.7 \\
\hline & Sodium & 38 & 24.6 & 5.1 & 11.6 \\
\hline & Bromide & 34 & .29 & $<.6$ & $<.6$ \\
\hline & Chloride & 40 & 42.2 & 8.56 & 23.9 \\
\hline & Fluoride & 38 & .3 & $<.17$ & .22 \\
\hline & Silica & 38 & 20.3 & E.072 & 8.6 \\
\hline & Sulfate & 38 & 539.9 & .12 & 48.3 \\
\hline & Boron $^{2}$ & 36 & 61.9 & 16.4 & 31.9 \\
\hline & Iron $^{2}$ & 38 & 167.3 & $<10$ & 13.9 \\
\hline & Manganese $^{2}$ & 38 & 383.6 & $<3$ & 26 \\
\hline
\end{tabular}

${ }^{1}$ Maximum values largely represent concentrations from a sample likely affected by nearby industrial waste.

${ }^{2}$ Concentrations in ug/L. 
Table 11. Nutrients, summary statistics of groundwater and surface-water quality data combined, Cedar Rapids, lowa, calendar years 1999-2005.

[mg/L, milligrams per liter; w, water; f, filtered; u, unfiltered]

\begin{tabular}{lcccc}
\hline Nutrient & $\begin{array}{c}\text { Number of } \\
\text { samples }\end{array}$ & $\begin{array}{c}\text { Maximum } \\
\text { concentration } \\
\text { (mg/L) }\end{array}$ & $\begin{array}{c}\text { Minimum } \\
\text { concentration } \\
\text { (mg/L) }\end{array}$ & $\begin{array}{c}\text { Average } \\
\text { (mg/L) }\end{array}$ \\
\hline $\mathrm{NH}_{3}+$ orgN, wf & 5 & 0.62 & 0.24 & 0.39 \\
$\mathrm{NH}_{3}+$ orgN, wu & 5 & 3.1 & 1 & 1.8 \\
$\mathrm{Ammonia}^{\mathrm{m}}$ & 306 & 22.6 & .01 & .6 \\
$\mathrm{NO}_{2}+\mathrm{NO}_{3}$ & 306 & 12.6 & .02 & 2.6 \\
$\mathrm{Nitrite}$ & 306 & .443 & .003 & .02 \\
Orthophosphate & 305 & .73 & .01 & .06 \\
Phosphorus, wf & 5 & .154 & .011 & .064 \\
Phosphorus, wu & 5 & .88 & .14 & .32 \\
Organic carbon & 271 & 12.7 & .65 & 2.4 \\
\hline
\end{tabular}

Table 12. Nutrients, summary statistics of water-quality data for groundwater and surfacewater sampling sites, Cedar Rapids, lowa, calendar years 1999-2005.

[mg/L, milligrams per liter; $\mathrm{w}$, water; f, filtered; u, unfiltered; --, no data]

\begin{tabular}{|c|c|c|c|c|c|}
\hline $\begin{array}{l}\text { Sample } \\
\text { medium }\end{array}$ & Nutrient & $\begin{array}{c}\text { Number of } \\
\text { samples }\end{array}$ & $\begin{array}{c}\text { Maximum } \\
\text { concentration } \\
(\mathrm{mg} / \mathrm{L})\end{array}$ & $\begin{array}{c}\text { Minimum } \\
\text { concentration } \\
(\mathrm{mg} / \mathrm{L})\end{array}$ & $\begin{array}{c}\text { Average } \\
\text { (mg/L) }\end{array}$ \\
\hline \multirow[t]{9}{*}{ Groundwater } & $\mathrm{NH}_{3}+\operatorname{orgN}, \mathrm{wf}$ & -- & -- & -- & -- \\
\hline & $\mathrm{NH}_{3}+\operatorname{orgN}, \mathrm{wu}$ & -- & -- & -- & -- \\
\hline & Ammonia & 262 & 22.6 & 0.01 & 0.6 \\
\hline & $\mathrm{NO}_{2}+\mathrm{NO}_{3}$ & 262 & 11.5 & .02 & 2.2 \\
\hline & Nitrite & 262 & .443 & .003 & .02 \\
\hline & Orthophosphate & 261 & .73 & .005 & .06 \\
\hline & Phosphorus, wf & -- & -- & -- & -- \\
\hline & Phosphorus, wu & -- & -- & -- & -- \\
\hline & Organic carbon & 236 & 6.6 & .7 & 2.2 \\
\hline \multirow[t]{9}{*}{ Surface water } & $\mathrm{NH}_{3}+\operatorname{orgN}$, wf & 5 & .62 & .24 & .39 \\
\hline & $\mathrm{NH}_{3}+\operatorname{orgN}, \mathrm{wu}$ & 5 & 3.1 & 1 & 1.8 \\
\hline & Ammonia & 44 & 5.16 & .01 & .15 \\
\hline & $\mathrm{NO}_{2}+\mathrm{NO}_{3}$ & 44 & 12.6 & .025 & 5.43 \\
\hline & Nitrite & 44 & .102 & .004 & .02 \\
\hline & Orthophosphate & 46 & .16 & .005 & .06 \\
\hline & Phosphorus, wf & 5 & .154 & .011 & .064 \\
\hline & Phosphorus, wu & 5 & .88 & .138 & .32 \\
\hline & Organic carbon & 35 & 12.7 & 2.12 & 3.9 \\
\hline
\end{tabular}


Table 13. Major ions and nutrients, summary statistics of groundwater and surface-water quality data by site, Cedar Rapids, lowa, calendar years 1999-2005.

$[\mathrm{mg} / \mathrm{L}$, milligrams per liter; <, actual value is known to be less than value shown; E, estimated; w, water; $\mathrm{f}$, filtered; $\mathrm{u}$, unfiltered; --, no data; $\mu \mathrm{g} / \mathrm{L}, \mathrm{micrograms}$ per liter]

\begin{tabular}{|c|c|c|c|c|c|}
\hline Site name & Constituent & $\begin{array}{c}\text { Number of } \\
\text { samples }\end{array}$ & $\begin{array}{c}\text { Maximum } \\
\text { concentration } \\
\text { (mg/L) }\end{array}$ & $\begin{array}{c}\text { Minimum } \\
\text { concentration } \\
\text { (mg/L) }\end{array}$ & $\begin{array}{c}\text { Average } \\
\text { (mg/L) }\end{array}$ \\
\hline \multirow[t]{17}{*}{${ }^{1} 1993$ USGS CRM-1 } & Calcium & 17 & 203 & 46.3 & 69 \\
\hline & Magnesium & 17 & 61.8 & 14.6 & 22.6 \\
\hline & Potassium & 17 & 10.7 & 1.16 & 3.38 \\
\hline & Sodium & 17 & 26.4 & 8.06 & 15 \\
\hline & Chloride & 17 & 43 & 17.6 & 28 \\
\hline & Fluoride & 17 & .3 & $<.17$ & .2 \\
\hline & Silica & 17 & 26.1 & 9.1 & 18 \\
\hline & Sulfate & 17 & 59 & E.15 & 21 \\
\hline & $\mathrm{NH}_{3}$ orgN, wf & -- & -- & -- & -- \\
\hline & $\mathrm{NH}_{3}+\operatorname{orgN}, \mathrm{wu}$ & -- & -- & -- & -- \\
\hline & Ammonia & 16 & 22.6 & .43 & 5.1 \\
\hline & $\mathrm{NO}_{2}+\mathrm{NO}_{3}$ & 16 & .03 & .025 & .03 \\
\hline & Nitrite & 16 & .014 & .003 & .006 \\
\hline & Orthophosphate & 16 & .73 & .01 & .19 \\
\hline & Phosphorus, wf & -- & -- & -- & -- \\
\hline & Phosphorus, wu & -- & -- & -- & -- \\
\hline & Organic carbon & 15 & 6.6 & 1.9 & 3 \\
\hline \multirow{11}{*}{ 1993USGS CRM-2 } & Chloride & 16 & 36.1 & 16.8 & 25.3 \\
\hline & Fluoride & 16 & .3 & .1 & .2 \\
\hline & Silica & 16 & 17.2 & 8.02 & 11.6 \\
\hline & Sulfate & 16 & 47.2 & 13.6 & 28.9 \\
\hline & Boron $^{2}$ & 16 & 48.3 & 17.1 & 27.1 \\
\hline & Iron $^{2}$ & 16 & 82.2 & 5 & 20 \\
\hline & Manganese $^{2}$ & 16 & 1,170 & 74.5 & 794 \\
\hline & $\mathrm{NH}_{3}+$ orgN, wf & -- & -- & -- & -- \\
\hline & $\mathrm{NH}_{3}+\operatorname{orgN}, \mathrm{wu}$ & -- & -- & -- & -- \\
\hline & Ammonia & 16 & 1.41 & .01 & .3 \\
\hline & $\mathrm{NO}_{2}+\mathrm{NO}_{3}$ & 16 & 6.07 & .025 & .78 \\
\hline
\end{tabular}


Table 13. Major ions and nutrients, summary statistics of groundwater and surface-water quality data by site, Cedar Rapids, lowa, calendar years 1999-2005.-Continued

$[\mathrm{mg} / \mathrm{L}$, milligrams per liter; <, actual value is known to be less than value shown; E, estimated; w, water; $\mathrm{f}$, filtered; u, unfiltered; --, no data; $\mu \mathrm{g} / \mathrm{L}$, micrograms per liter]

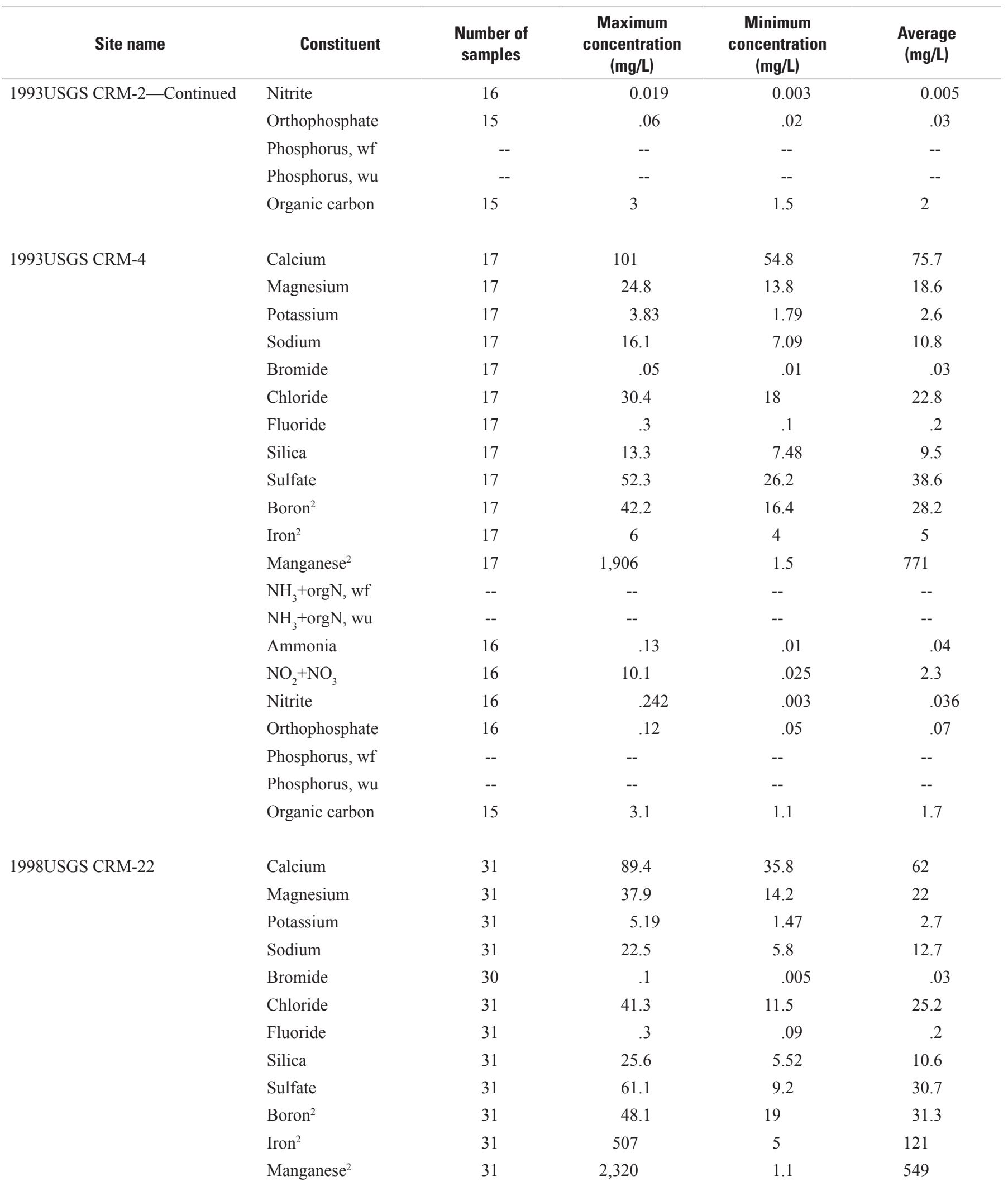


Table 13. Major ions and nutrients, summary statistics of groundwater and surface-water quality data by site, Cedar Rapids, lowa, calendar years 1999-2005.-Continued

$[\mathrm{mg} / \mathrm{L}$, milligrams per liter; <, actual value is known to be less than value shown; E, estimated; w, water; $\mathrm{f}$, filtered; $\mathrm{u}$, unfiltered; --, no data; $\mu \mathrm{g} / \mathrm{L}, \mathrm{micrograms}$ per liter]

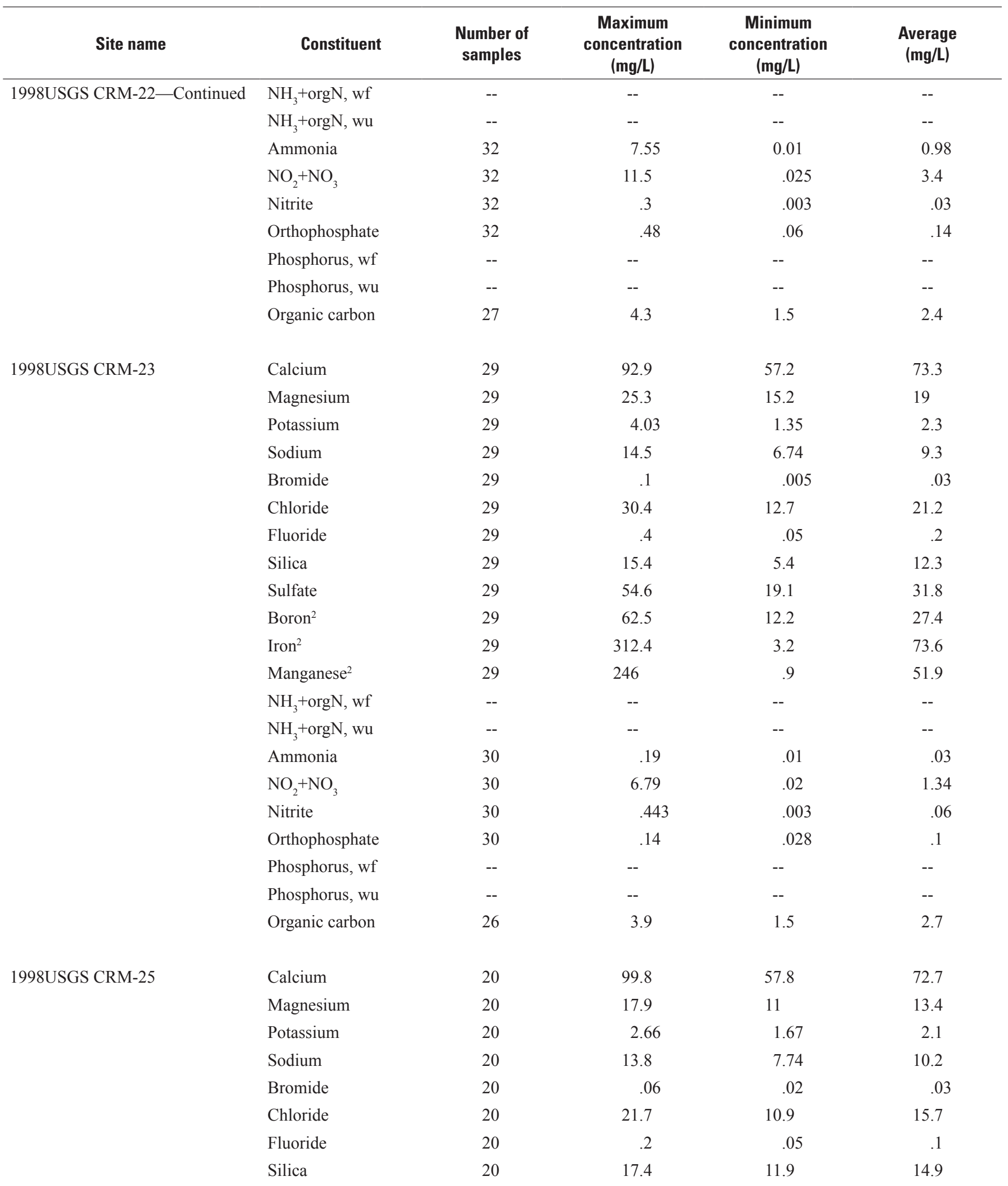


Table 13. Major ions and nutrients, summary statistics of groundwater and surface-water quality data by site, Cedar Rapids, lowa, calendar years 1999-2005.-Continued

$[\mathrm{mg} / \mathrm{L}$, milligrams per liter; <, actual value is known to be less than value shown; E, estimated; w, water; $\mathrm{f}$, filtered; u, unfiltered; --, no data; $\mu \mathrm{g} / \mathrm{L}$, micrograms per liter]

\begin{tabular}{|c|c|c|c|c|c|}
\hline Site name & Constituent & $\begin{array}{l}\text { Number of } \\
\text { samples }\end{array}$ & $\begin{array}{c}\text { Maximum } \\
\text { concentration } \\
\text { (mg/L) }\end{array}$ & $\begin{array}{c}\text { Minimum } \\
\text { concentration } \\
\text { (mg/L) }\end{array}$ & $\begin{array}{c}\text { Average } \\
\text { (mg/L) }\end{array}$ \\
\hline \multirow[t]{9}{*}{ 1998USGS CRM-25-Continued } & Sulfate & 20 & 83.7 & 0.2 & 48 \\
\hline & Boron $^{2}$ & 20 & 115.6 & 42.4 & 93.6 \\
\hline & Iron $^{2}$ & 20 & 12.6 & 4 & 6 \\
\hline & Manganese $^{2}$ & 20 & 5.7 & 0.3 & 2 \\
\hline & $\mathrm{NH}_{3}+\operatorname{orgN}$, wu & -- & -- & -- & -- \\
\hline & Ammonia & 21 & .07 & .01 & .02 \\
\hline & $\mathrm{NO}_{2}+\mathrm{NO}_{3}$ & 21 & 7.66 & 3.05 & 5.1 \\
\hline & Nitrite & 21 & .017 & .003 & .005 \\
\hline & Organic carbon & 16 & 1.6 & .7 & 1 \\
\hline \multirow[t]{15}{*}{ 1998USGS CRM-26 } & Calcium & 20 & 113 & 57 & 75.6 \\
\hline & Magnesium & 20 & 29.6 & 15.5 & 21.1 \\
\hline & Potassium & 20 & 3.43 & 1.94 & 2.7 \\
\hline & Sodium & 20 & 16.3 & 7.46 & 11.5 \\
\hline & Bromide & 20 & .06 & .02 & .03 \\
\hline & Chloride & 20 & 32.3 & 17.5 & 23.4 \\
\hline & Fluoride & 20 & .3 & .2 & 0.2 \\
\hline & $\mathrm{NH}_{3}+\operatorname{orgN}$, wu & -- & -- & -- & -- \\
\hline & Ammonia & 20 & .8 & .01 & .06 \\
\hline & $\mathrm{NO}_{2}+\mathrm{NO}_{3}$ & 20 & 2.75 & .025 & .48 \\
\hline & Nitrite & 20 & .055 & .003 & .01 \\
\hline & Orthophosphate & 20 & .04 & .005 & .02 \\
\hline & Phosphorus, wf & -- & -- & -- & -- \\
\hline & Phosphorus, wu & -- & -- & -- & -- \\
\hline & Organic carbon & 16 & 3.1 & 1.6 & 2.1 \\
\hline \multirow[t]{4}{*}{ 1998USGS CRM-27 } & Calcium & 20 & 106.3 & 77.5 & 90.1 \\
\hline & Magnesium & 20 & 22.4 & 17.4 & 20.5 \\
\hline & Potassium & 20 & 3.65 & 2.35 & 3 \\
\hline & Sodium & 20 & 12.4 & 7 & 8.3 \\
\hline
\end{tabular}


Table 13. Major ions and nutrients, summary statistics of groundwater and surface-water quality data by site, Cedar Rapids, lowa, calendar years 1999-2005.-Continued

$[\mathrm{mg} / \mathrm{L}$, milligrams per liter; <, actual value is known to be less than value shown; E, estimated; w, water; f, filtered; u, unfiltered; --, no data; $\mu \mathrm{g} / \mathrm{L}, \mathrm{micrograms}$ per liter]

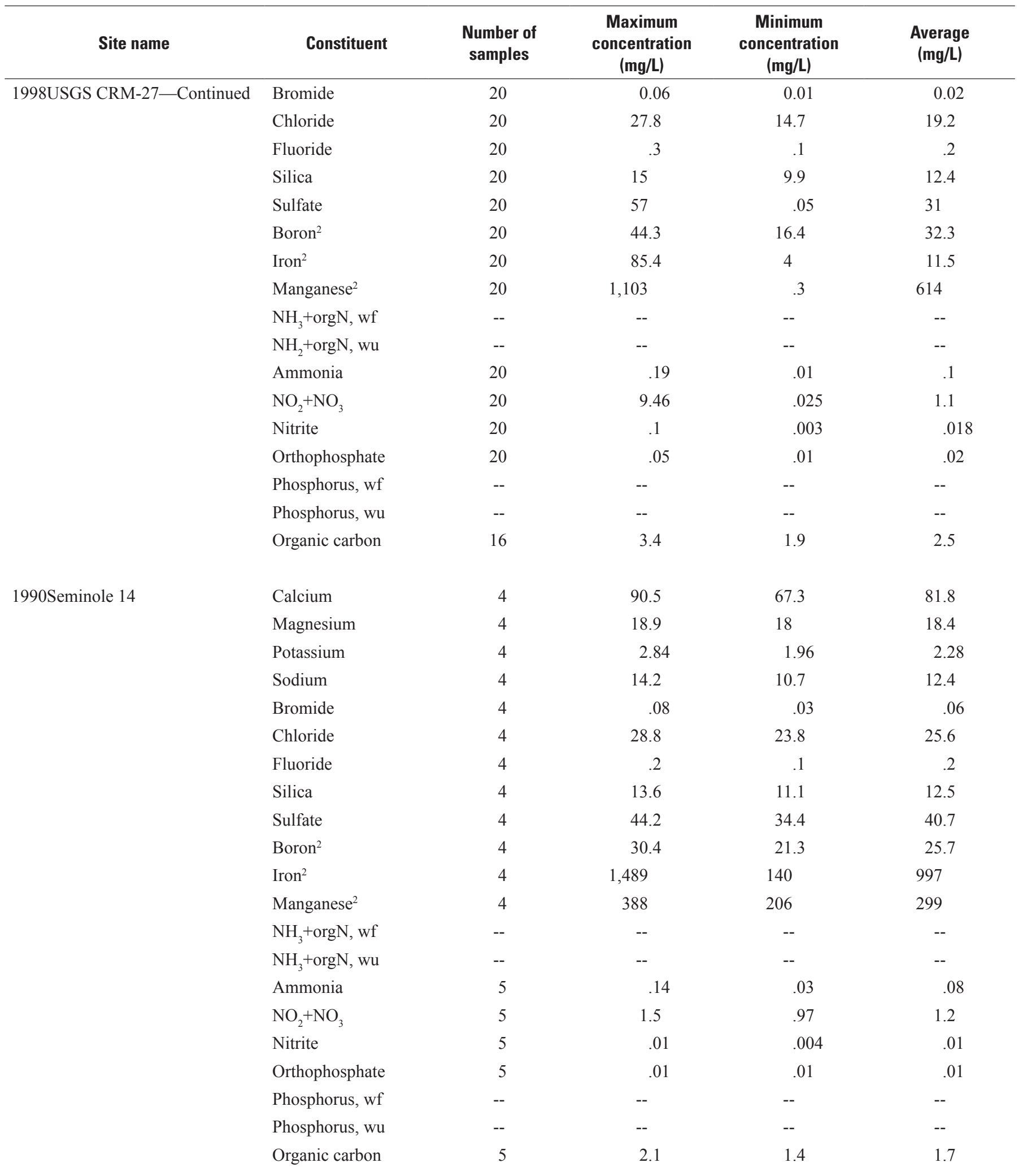


Table 13. Major ions and nutrients, summary statistics of groundwater and surface-water quality data by site, Cedar Rapids, lowa, calendar years 1999-2005.-Continued

$[\mathrm{mg} / \mathrm{L}$, milligrams per liter; <, actual value is known to be less than value shown; E, estimated; w, water; $\mathrm{f}$, filtered; u, unfiltered; --, no data; $\mu \mathrm{g} / \mathrm{L}$, micrograms per liter]

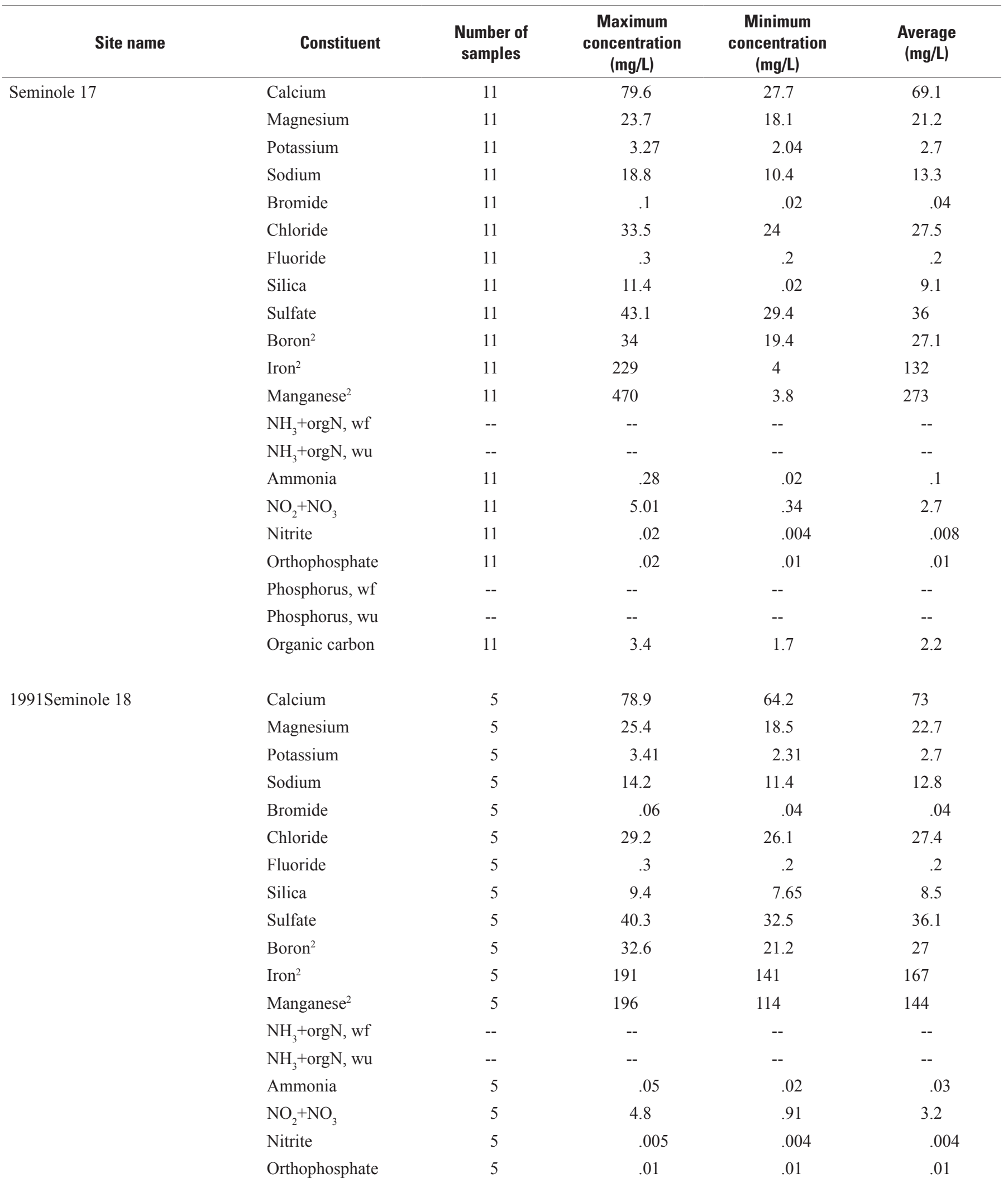


Table 13. Major ions and nutrients, summary statistics of groundwater and surface-water quality data by site, Cedar Rapids, lowa, calendar years 1999-2005.-Continued

$[\mathrm{mg} / \mathrm{L}$, milligrams per liter; <, actual value is known to be less than value shown; E, estimated; w, water; f, filtered; u, unfiltered; --, no data; $\mu \mathrm{g} / \mathrm{L}$, micrograms per liter]

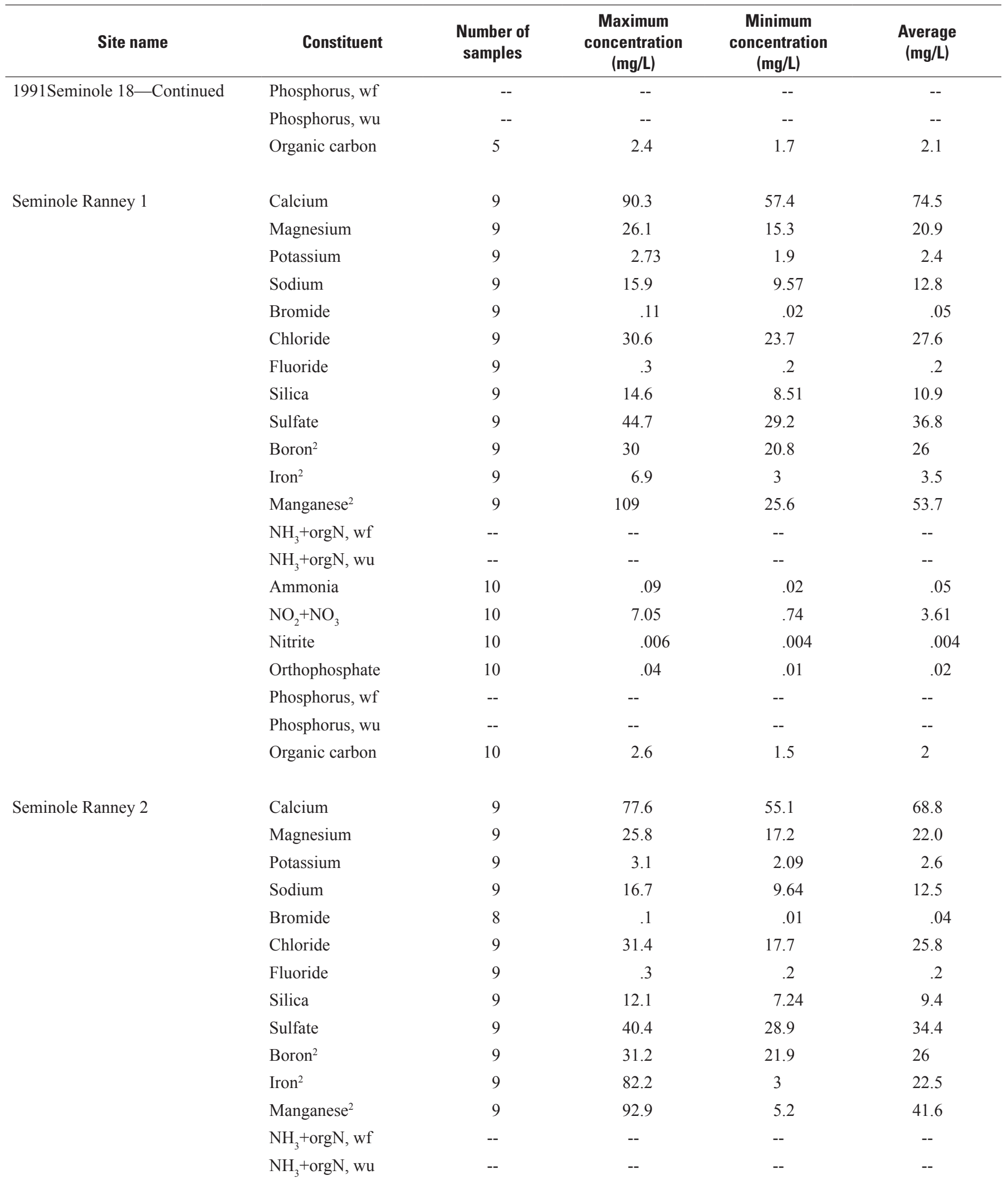


Table 13. Major ions and nutrients, summary statistics of groundwater and surface-water quality data by site, Cedar Rapids, lowa, calendar years 1999-2005. - Continued

$[\mathrm{mg} / \mathrm{L}$, milligrams per liter; <, actual value is known to be less than value shown; E, estimated; w, water; f, filtered; $\mathrm{u}$, unfiltered; --, no data; $\mu \mathrm{g} / \mathrm{L}$, micrograms per liter]

\begin{tabular}{|c|c|c|c|c|c|}
\hline Site name & Constituent & $\begin{array}{c}\text { Number of } \\
\text { samples }\end{array}$ & $\begin{array}{c}\text { Maximum } \\
\text { concentration } \\
(\mathrm{mg} / \mathrm{L})\end{array}$ & $\begin{array}{c}\text { Minimum } \\
\text { concentration } \\
\text { (mg/L) }\end{array}$ & $\begin{array}{c}\text { Average } \\
\text { (mg/L) }\end{array}$ \\
\hline \multirow[t]{5}{*}{ Seminole Ranney 2-Continued } & Ammonia & 9 & 0.07 & 0.02 & 0.03 \\
\hline & $\mathrm{NO}_{2}+\mathrm{NO}_{3}$ & 9 & 8.07 & 1.39 & 4.54 \\
\hline & Nitrite & 9 & .006 & .004 & .004 \\
\hline & Phosphorus, wu & -- & -- & -- & -- \\
\hline & Organic carbon & 9 & 2.6 & 1.7 & 2 \\
\hline \multirow[t]{12}{*}{ Edgewood Ranney } & Calcium & 12 & 84 & 64.3 & 73.7 \\
\hline & Bromide & 10 & .1 & .02 & .04 \\
\hline & Chloride & 12 & 38.5 & 21.6 & 28.7 \\
\hline & Fluoride & 12 & .3 & .2 & .2 \\
\hline & Silica & 12 & 16.8 & 11.9 & 14.4 \\
\hline & Sulfate & 12 & 46.3 & 25.6 & 32.5 \\
\hline & Boron $^{2}$ & 12 & 34 & 23.4 & 28.1 \\
\hline & Iron $^{2}$ & 12 & 241 & 3.2 & 49.1 \\
\hline & Manganese $^{2}$ & 12 & 1,370 & 364 & 730 \\
\hline & $\mathrm{NH}_{3}+\operatorname{orgN}, \mathrm{wf}$ & -- & -- & -- & -- \\
\hline & Phosphorus, wu & -- & -- & -- & -- \\
\hline & Organic carbon & 12 & 2.6 & 1.5 & 2.2 \\
\hline \multirow[t]{10}{*}{ Seminole Ranney 4} & Calcium & 11 & 87 & 62.9 & 74.6 \\
\hline & Magnesium & 11 & 27.3 & 17.1 & 22 \\
\hline & Potassium & 11 & 2.95 & 2.4 & 2.7 \\
\hline & Sodium & 11 & 18.2 & 10.1 & 13.4 \\
\hline & Bromide & 11 & .1 & .02 & .04 \\
\hline & Chloride & 11 & 34.9 & 20.3 & 27.8 \\
\hline & Fluoride & 11 & .3 & .2 & .2 \\
\hline & Silica & 11 & 13.3 & 10.7 & 11.8 \\
\hline & Sulfate & 11 & 51.9 & 29.1 & 38.3 \\
\hline & Boron $^{2}$ & 11 & 39.4 & 23 & 29.6 \\
\hline
\end{tabular}


Table 13. Major ions and nutrients, summary statistics of groundwater and surface-water quality data by site, Cedar Rapids, lowa, calendar years 1999-2005.-Continued

$[\mathrm{mg} / \mathrm{L}$, milligrams per liter; <, actual value is known to be less than value shown; E, estimated; w, water; f, filtered; u, unfiltered; --, no data; $\mu \mathrm{g} / \mathrm{L}$, micrograms per liter]

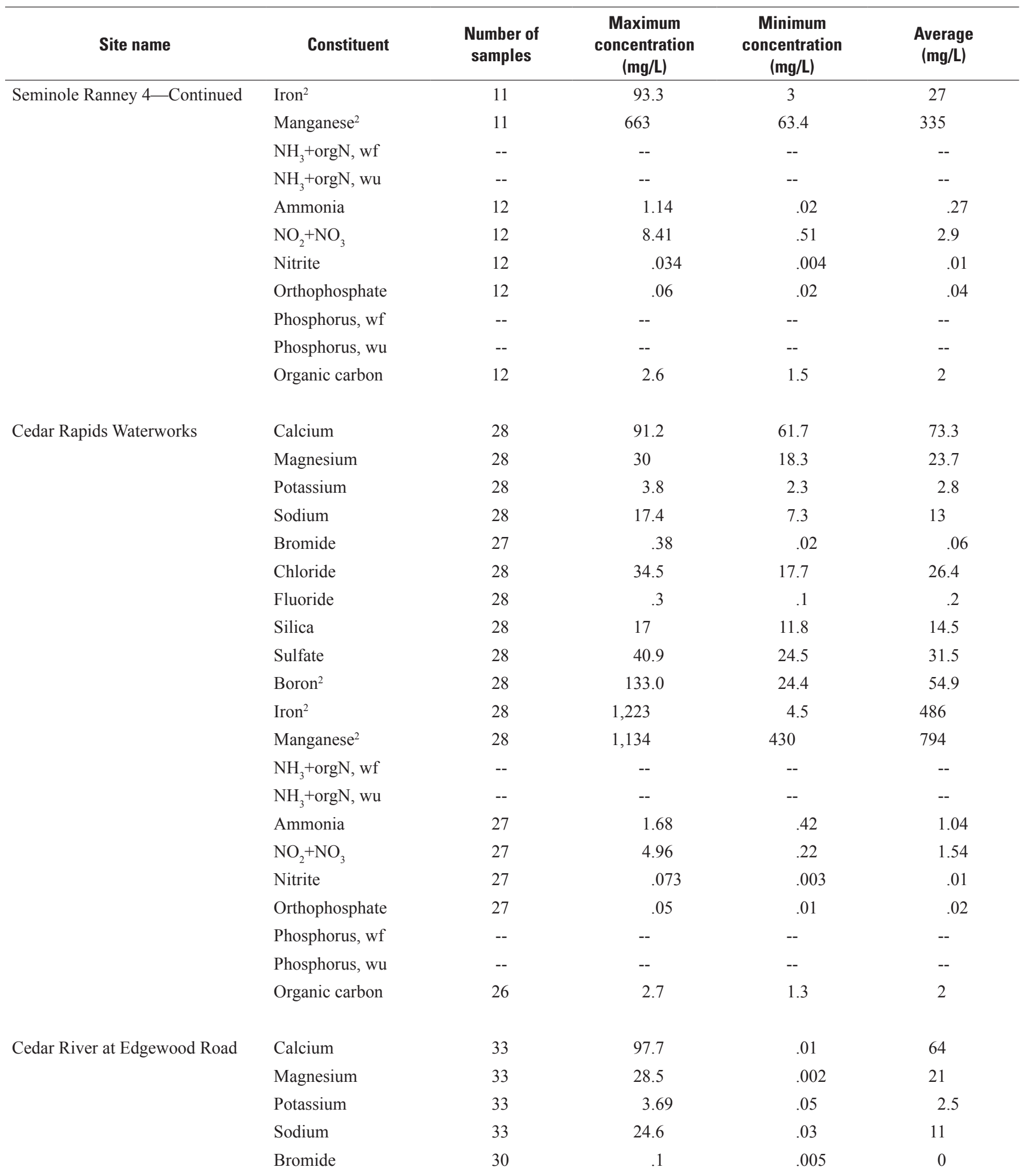


Table 13. Major ions and nutrients, summary statistics of groundwater and surface-water quality data by site, Cedar Rapids, lowa, calendar years 1999-2005.-Continued

$[\mathrm{mg} / \mathrm{L}$, milligrams per liter; <, actual value is known to be less than value shown; E, estimated; w, water; f, filtered; u, unfiltered; --, no data; $\mu \mathrm{g} / \mathrm{L}, \mathrm{micrograms}$ per liter]

\begin{tabular}{|c|c|c|c|c|c|}
\hline Site name & Constituent & $\begin{array}{l}\text { Number of } \\
\text { samples }\end{array}$ & $\begin{array}{c}\text { Maximum } \\
\text { concentration } \\
\text { (mg/L) }\end{array}$ & $\begin{array}{c}\text { Minimum } \\
\text { concentration } \\
\text { (mg/L) }\end{array}$ & $\begin{array}{c}\text { Average } \\
\text { (mg/L) }\end{array}$ \\
\hline \multirow{12}{*}{$\begin{array}{l}\text { Cedar River at Edgewood Road- } \\
\text { Continued }\end{array}$} & Chloride & 35 & 42.2 & 0.05 & 24 \\
\hline & Fluoride & 33 & .3 & .05 & .2 \\
\hline & Silica & 33 & 20.3 & .025 & 9 \\
\hline & Sulfate & 33 & 47.1 & .05 & 30 \\
\hline & Iron $^{2}$ & 33 & 167 & 3 & 13 \\
\hline & Manganese $^{2}$ & 33 & 384 & 1.5 & 19 \\
\hline & $\mathrm{NH}_{3}+$ orgN, wf & 5 & .62 & .24 & .39 \\
\hline & $\mathrm{NH}_{3}+\operatorname{orgN}$, wu & 5 & 3.1 & 1 & 1.8 \\
\hline & Orthophosphate & 39 & .16 & .005 & .07 \\
\hline & Phosphorus, wf & 5 & .154 & .011 & .06 \\
\hline & Phosphorus, wu & 5 & .88 & .138 & .32 \\
\hline & Organic carbon & 30 & 6.1 & 2.1 & 3.3 \\
\hline \multirow[t]{15}{*}{ Wetland Pond at CRM-27 } & Calcium & 5 & 166 & 63.2 & 93.3 \\
\hline & Magnesium & 5 & 43.5 & 16.8 & 25.2 \\
\hline & Potassium & 5 & 5.86 & 2.06 & 4.01 \\
\hline & Sodium & 5 & 16.2 & 7.95 & 11.2 \\
\hline & Iron $^{2}$ & 5 & 51.9 & 4 & 19.2 \\
\hline & Manganese $^{2}$ & 5 & 178 & 5.2 & 70 \\
\hline & $\mathrm{NH}_{3}+$ orgN, wf & -- & -- & -- & -- \\
\hline & $\mathrm{NH}_{3}+$ orgN, wu & -- & -- & -- & -- \\
\hline & Ammonia & 5 & 5.16 & .02 & 1.06 \\
\hline & $\mathrm{NO}_{2}+\mathrm{NO}_{3}$ & 5 & 8.88 & .03 & 2 \\
\hline & Nitrite & 5 & .102 & .004 & .04 \\
\hline & Orthophosphate & 5 & .06 & .01 & .03 \\
\hline & Phosphorus, wf & -- & -- & -- & -- \\
\hline & Phosphorus, wu & -- & -- & -- & -- \\
\hline & Organic carbon & 5 & 12.7 & 4 & 7.6 \\
\hline
\end{tabular}

\footnotetext{
${ }^{1}$ Maximum values largely represent concentrations from a sample likely affected by nearby industrial waste.
}

${ }^{2}$ Concentrations in $\mu \mathrm{g} / \mathrm{L}$. 
Table 14. Information on pesticides and pesticide degradates tested at water-quality sampling sites, Cedar Rapids, lowa, calendar years 1999-2005.

[NWIS, National Water Information System; CASRN, Chemical Abstract Service Registry Number; --, not available]

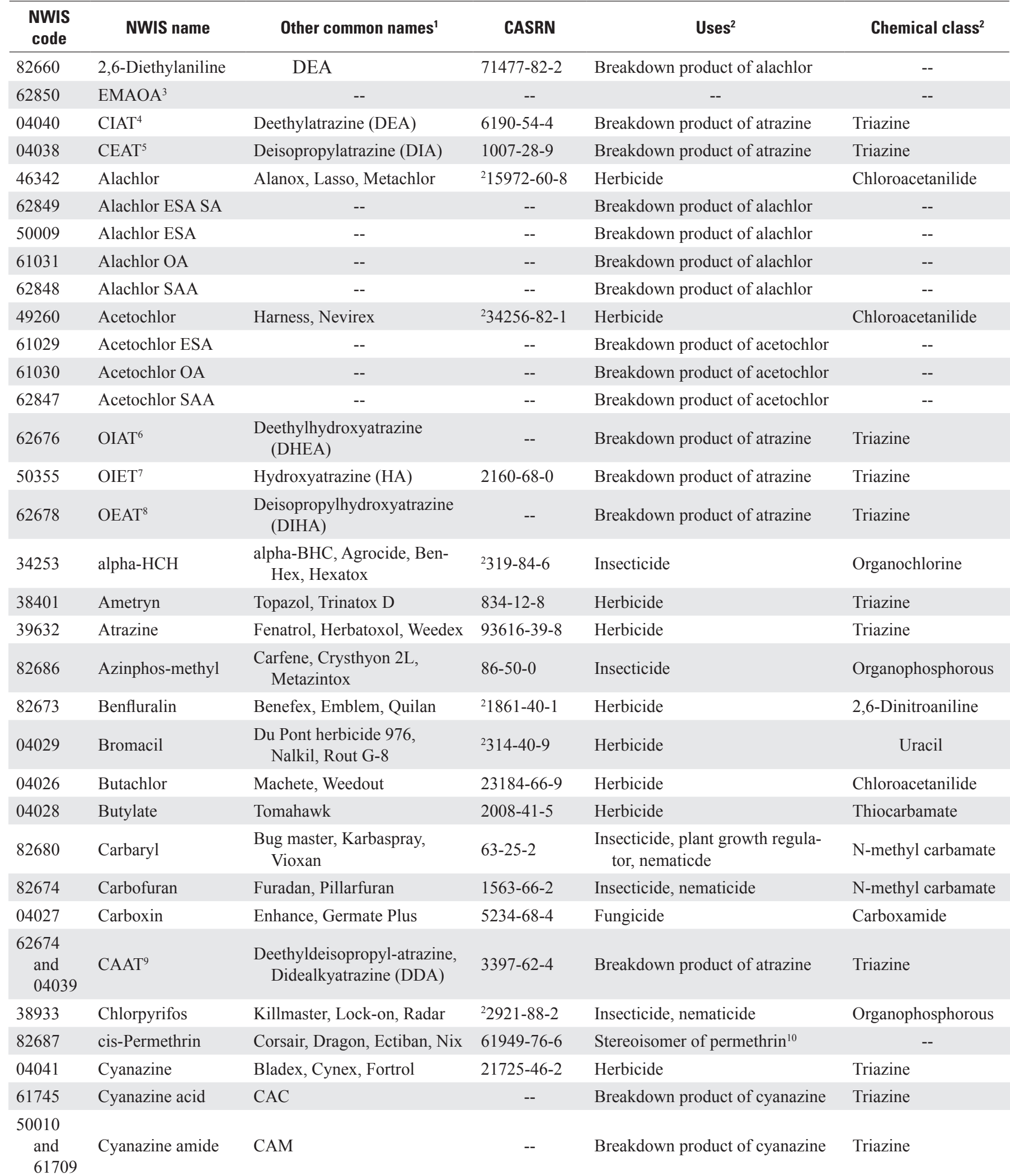


Table 14. Information on pesticides and pesticide degradates tested at water-quality sampling sites, Cedar Rapids, lowa, calendar years 1999-2005.-Continued

[NWIS, National Water Information System; CASRN, Chemical Abstract Service Registry Number; --, not available]

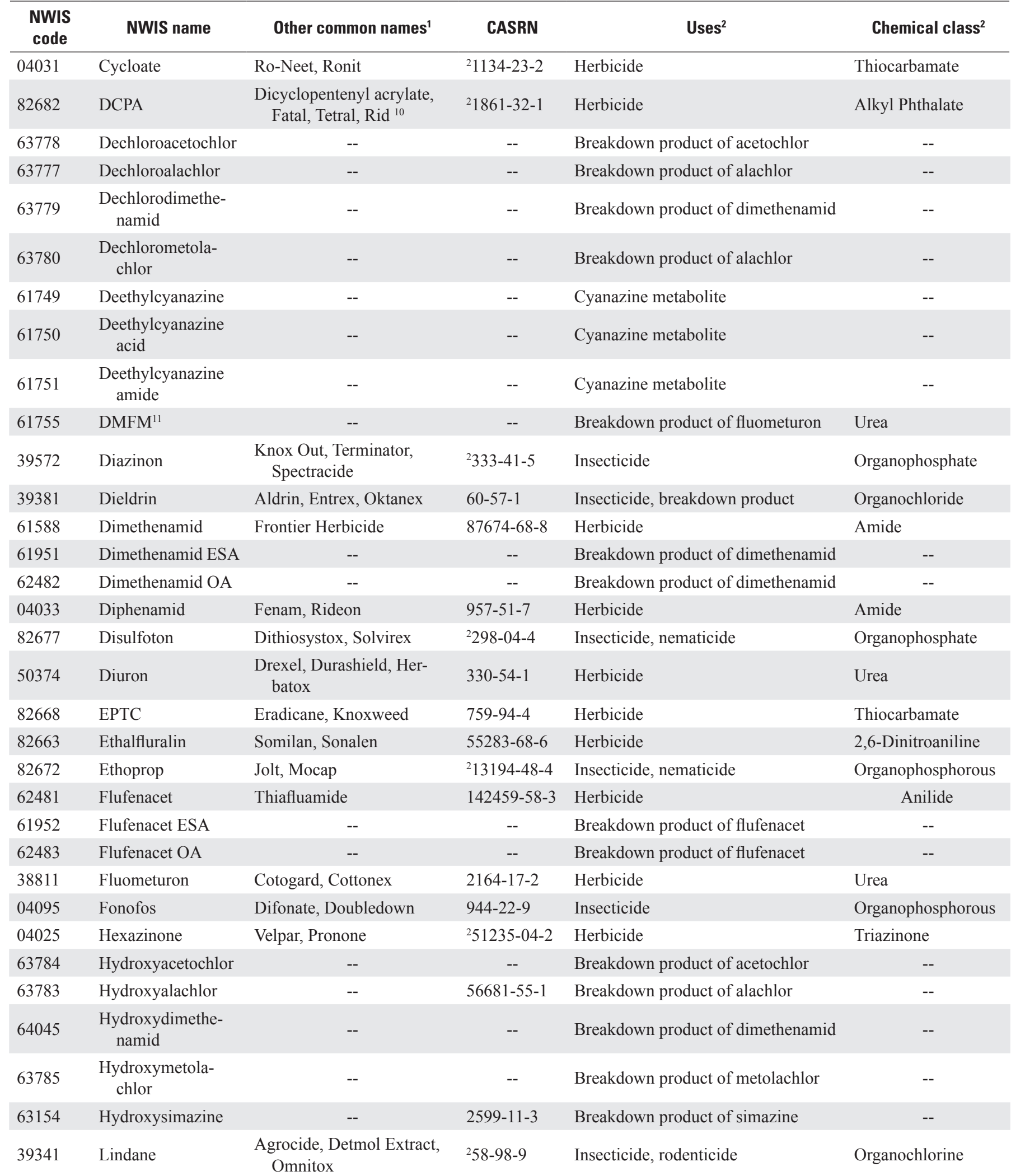


Table 14. Information on pesticides and pesticide degradates tested at water-quality sampling sites, Cedar Rapids, lowa, calendar years 1999-2005. - Continued

[NWIS, National Water Information System; CASRN, Chemical Abstract Service Registry Number; --, not available]

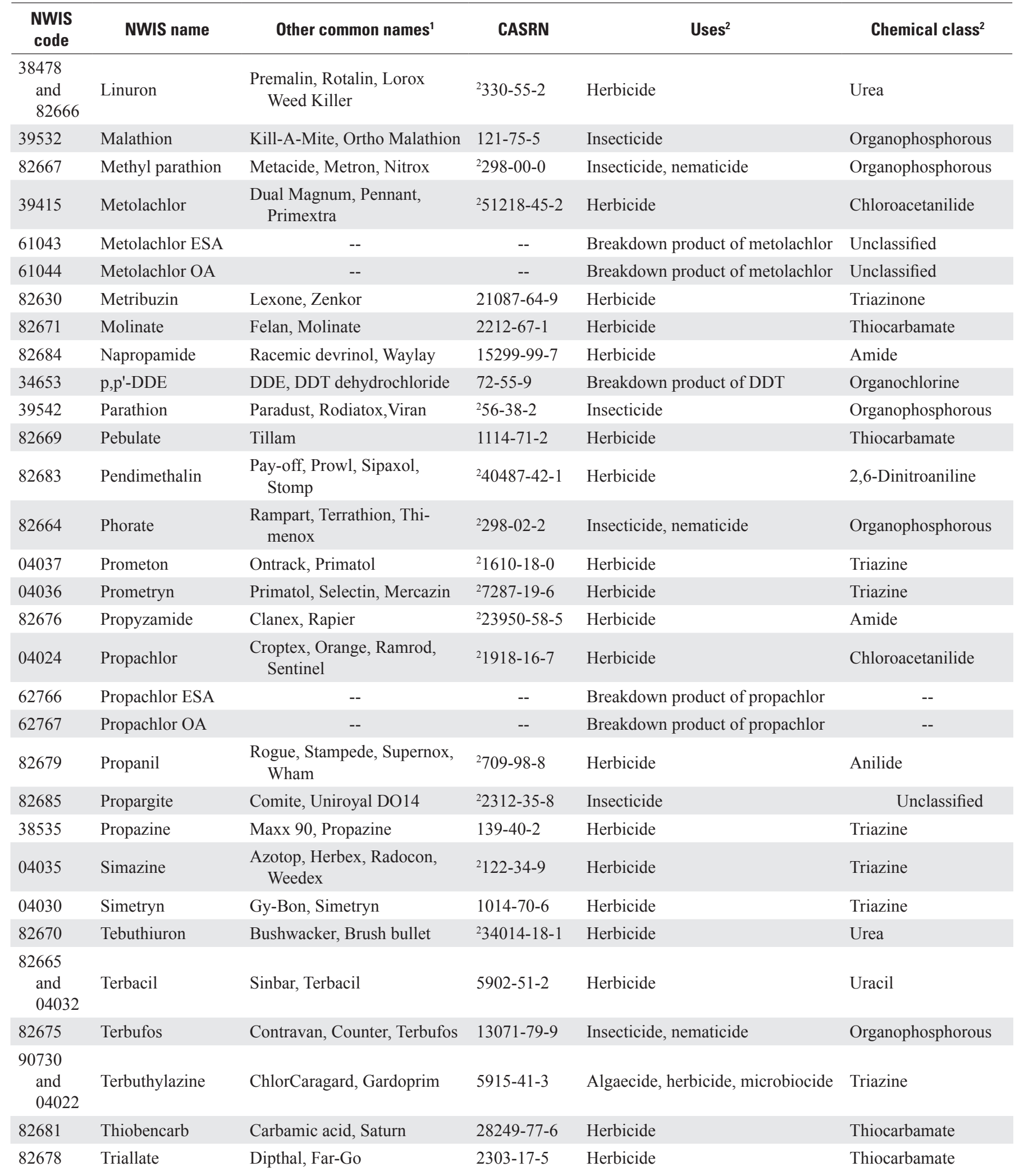


Table 14. Information on pesticides and pesticide degradates tested at water-quality sampling sites, Cedar Rapids, lowa, calendar years 1999-2005.-Continued

[NWIS, National Water Information System; CASRN, Chemical Abstract Service Registry Number; --, not available]

\begin{tabular}{clcccc}
\hline $\begin{array}{c}\text { NWIS } \\
\text { code }\end{array}$ & NWIS name & Other common names ${ }^{1}$ & CASRN & Uses $^{2}$ & Chemical class $^{2}$ \\
\hline $\begin{array}{c}82661 \\
\text { and } \\
04023\end{array}$ & Trifluralin & $\begin{array}{c}\text { Heritage, Trifloran, Trigard, } \\
\text { Tristar }\end{array}$ & $21582-09-8$ & Herbicide & 2,6-Dinitroaniline \\
04034 & Vernolate & PPTC, Surpass, Vernolate & $1929-77-7$ & Herbicide & Thiocarbamate \\
\hline
\end{tabular}

${ }^{1}$ From http://www.chemindustry.com (unless otherwise noted).

${ }^{2}$ From http://www.pesticideinfo.org/Index.html.

${ }^{3}$ 2-[(2-Ethyl-6-methylphenyl)amino]-2-oxoethanesulfonic acid (EMAOA, the abbreviation given is the author's).

${ }^{4}$ 2-Chloro-4-isopropylamino-6-amino-s-triazine (CIAT).

5 2-Chloro-6-ethylamino-4-amino-s-triazine (CEAT).

${ }^{6}$ 2-Hydroxy-4-isopropyl-6-amino-s-triazine (OIAT).

${ }^{7}$ 2-Hydroxy-4-isopropylamino-6-ethylamino-s-triazine (OIET).

8 2-Hydroxy-6-ethylamino-4-amino-s-triazine (OEAT).

${ }^{9}$ Chlorodiamino-s-triazine (CAAT).

${ }^{10}$ From http://webbook.nist.gov/.

${ }^{11}$ Demethylfluometuron (DMFM).

Table 15. Pesticides that were not detected in water-quality samples, Cedar Rapids, lowa, calendar years 1999-2005.

[NWIS, National Water Inventory System; LRL, laboratory reporting level; $\mu \mathrm{g} / \mathrm{L}$, micrograms per liter]

\begin{tabular}{ccc}
\hline $\begin{array}{c}\text { NWIS } \\
\text { parameter } \\
\text { code }\end{array}$ & $\begin{array}{c}\text { Pesticides } \\
\text { (not detected) }\end{array}$ & $\begin{array}{c}\text { LRL } \\
(\boldsymbol{\mu g} / \mathbf{L})\end{array}$ \\
\hline 04024 & Propachlor & 0.05 \\
04025 & Hexazione & .05 \\
04026 & Butachlor & .05 \\
04027 & Carboxin & .05 \\
04028 & Butaylate & .05 \\
04030 & Simetryn & .05 \\
04034 & Vernolate & .05 \\
04036 & Prometryn & .05 \\
\hline
\end{tabular}


Table 16. Pesticide degradates that were not detected in water-quality samples, Cedar Rapids, lowa, calendar years 1999-2005.

[NWIS, National Water Inventory System; LRL, laboratory reporting level; $\mu \mathrm{g} / \mathrm{L}$, micrograms per liter]

\begin{tabular}{|c|c|c|}
\hline $\begin{array}{l}\text { NWIS } \\
\text { parameter } \\
\text { code }\end{array}$ & Pesticides (not detected) & $\begin{array}{l}\text { LRL } \\
(\mu g / L)\end{array}$ \\
\hline 38478 & Linuron & 0.2 \\
\hline 38811 & Fluometuron & .2 \\
\hline 50374 & Diuron & .2 \\
\hline 61588 & Dimethenamid & .2 \\
\hline 61709 & Cyanazine amide & .025 \\
\hline 61745 & Cyanazine acid & .025 \\
\hline 61749 & Deethyl cyanazine & .2 \\
\hline 61751 & Deethyl cyanazine amide & .025 \\
\hline 61755 & Demethyl fluometuron & .2 \\
\hline 61952 & Flufenacet ethanesulfonic acid & .02 \\
\hline 62481 & Flufenacet & .02 \\
\hline 62482 & Dimethenamid oxanilic acid & .02 \\
\hline 62483 & Flufenacet oxanilic acid & .02 \\
\hline 62676 & $\begin{array}{l}\text { 2-Hydroxy-4-isopropylamino-6- } \\
\text { amino-s-triazine (OIAT) }\end{array}$ & .025 \\
\hline 62766 & Propachlor ethanesulfonic acid & .05 \\
\hline 62767 & Propachlor oxanilic acid & .02 \\
\hline 63154 & Hydroxysimazine & .025 \\
\hline 63777 & Decholoroalachlor & .02 \\
\hline 63778 & Dechloroacetochlor & .02 \\
\hline 63779 & Dechlorodimethnenamid & .02 \\
\hline 63781 & $\begin{array}{l}\text { 2-Chloro-N-(2,6-diethylphenyl) } \\
\text { acetamide (Alachlor 2nd } \\
\text { amide) }\end{array}$ & .02 \\
\hline 63782 & $\begin{array}{l}\text { 2-Chloro-N-(2-ethyl-6-methyl- } \\
\text { phenyl)acetamide (Acetochlor } \\
\text { 2nd amide) }\end{array}$ & .02 \\
\hline 63783 & Hydroxyalachlor & .02 \\
\hline 63784 & Hydroxyacetochlor & .02 \\
\hline 63785 & Hydroxymetolachlor & .02 \\
\hline 64045 & Hydroxydimethenamid & .02 \\
\hline
\end{tabular}




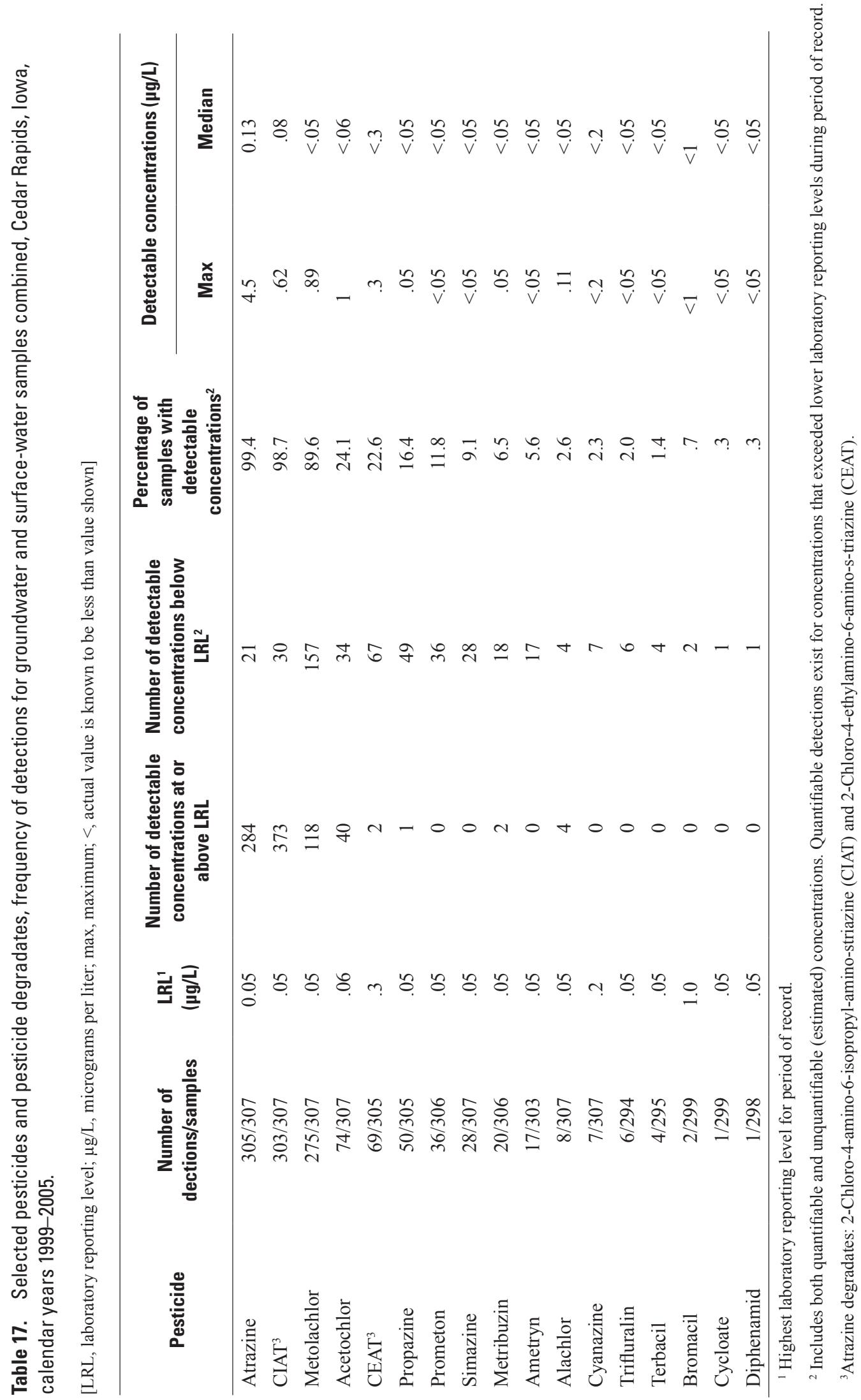




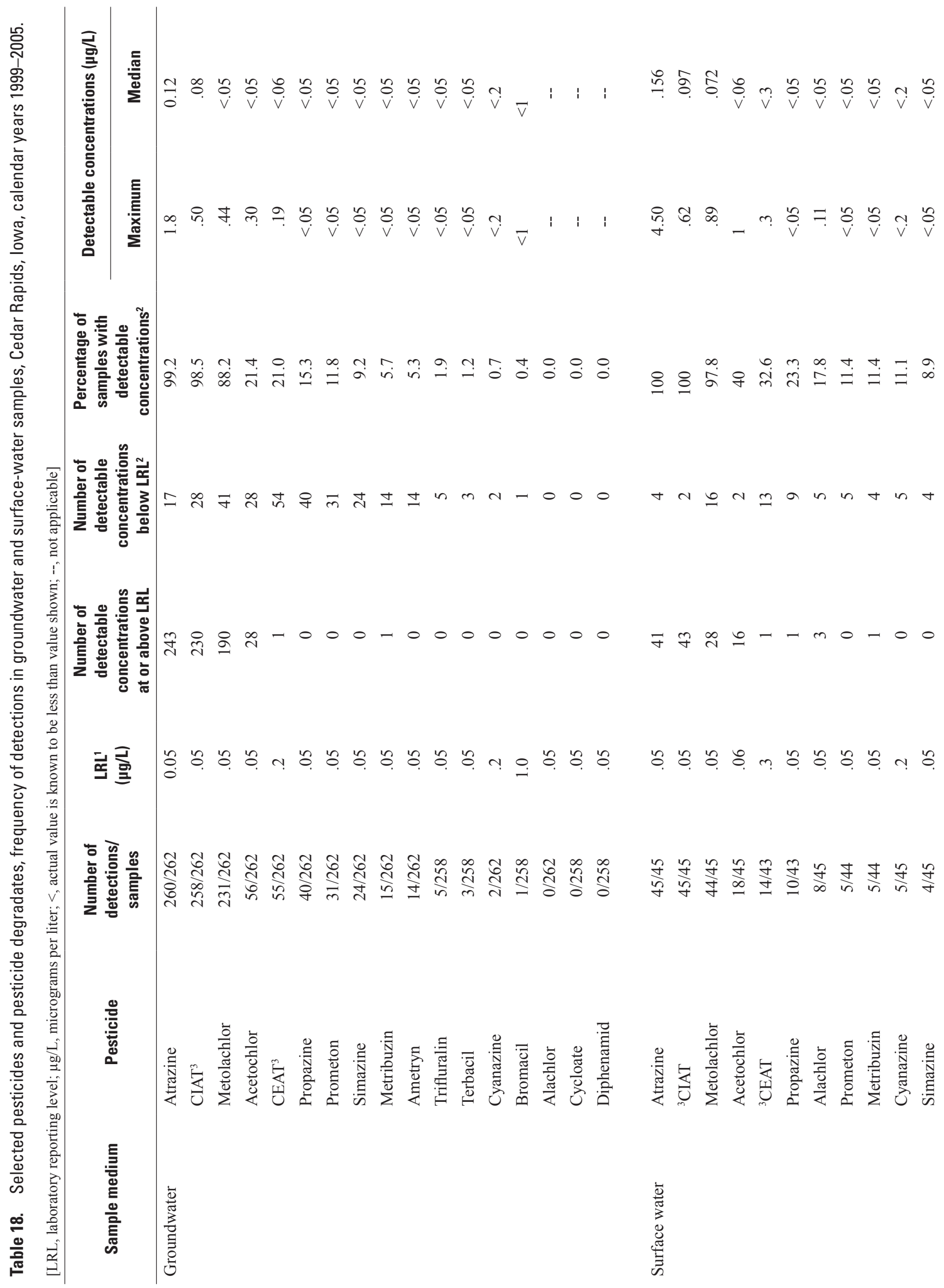




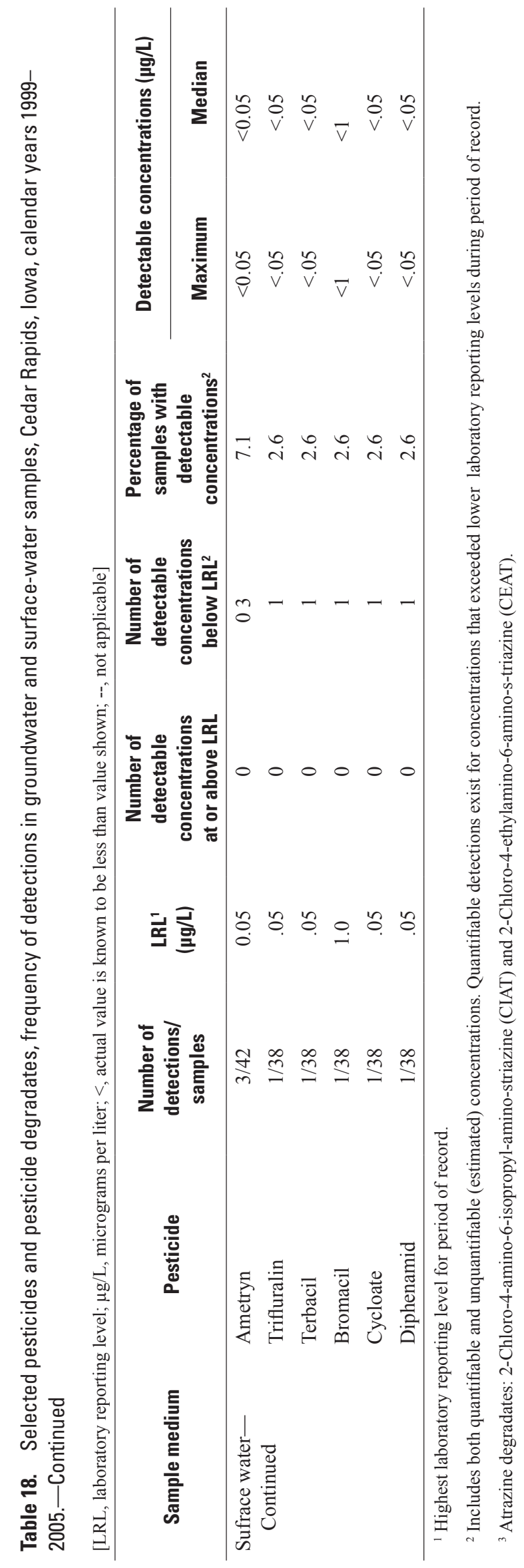


Table 19. Selected pesticides and pesticide degradates, frequency of detections in groundwater and surface-water samples by site, Cedar Rapids, lowa, calendar years 1999-2005.

[LRL, laboratory reporting level; $\mu \mathrm{g} / \mathrm{L}$, micrograms per liter; <, actual value is known to be less than value shown; --, not applicable]

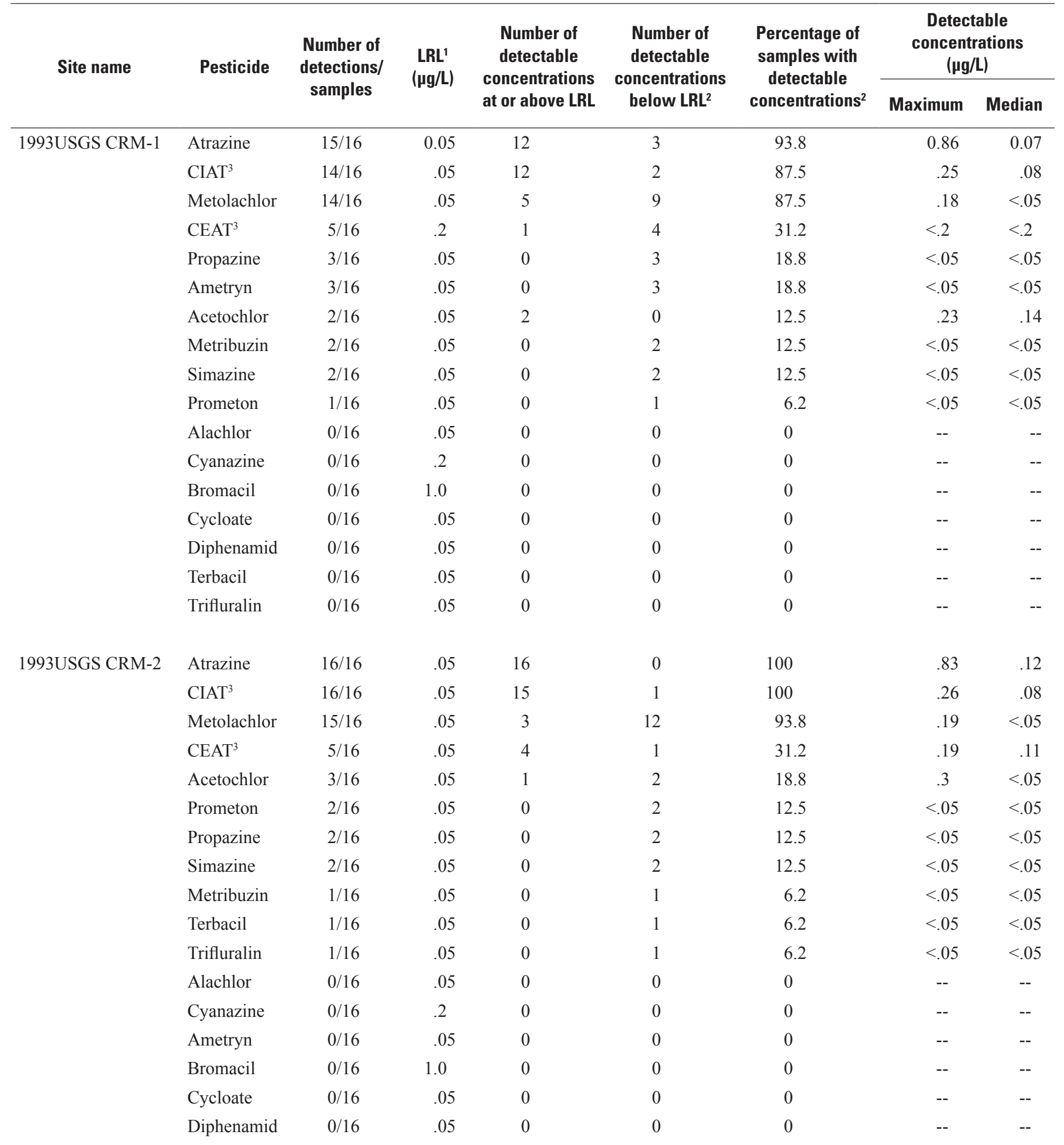


Table 19. Selected pesticides and pesticide degradates, frequency of detections in groundwater and surface-water samples by site, Cedar Rapids, lowa, calendar years 1999-2005. - Continued

[LRL, laboratory reporting level; $\mu \mathrm{g} / \mathrm{L}$, micrograms per liter; <, actual value is known to be less than value shown; --, not applicable]

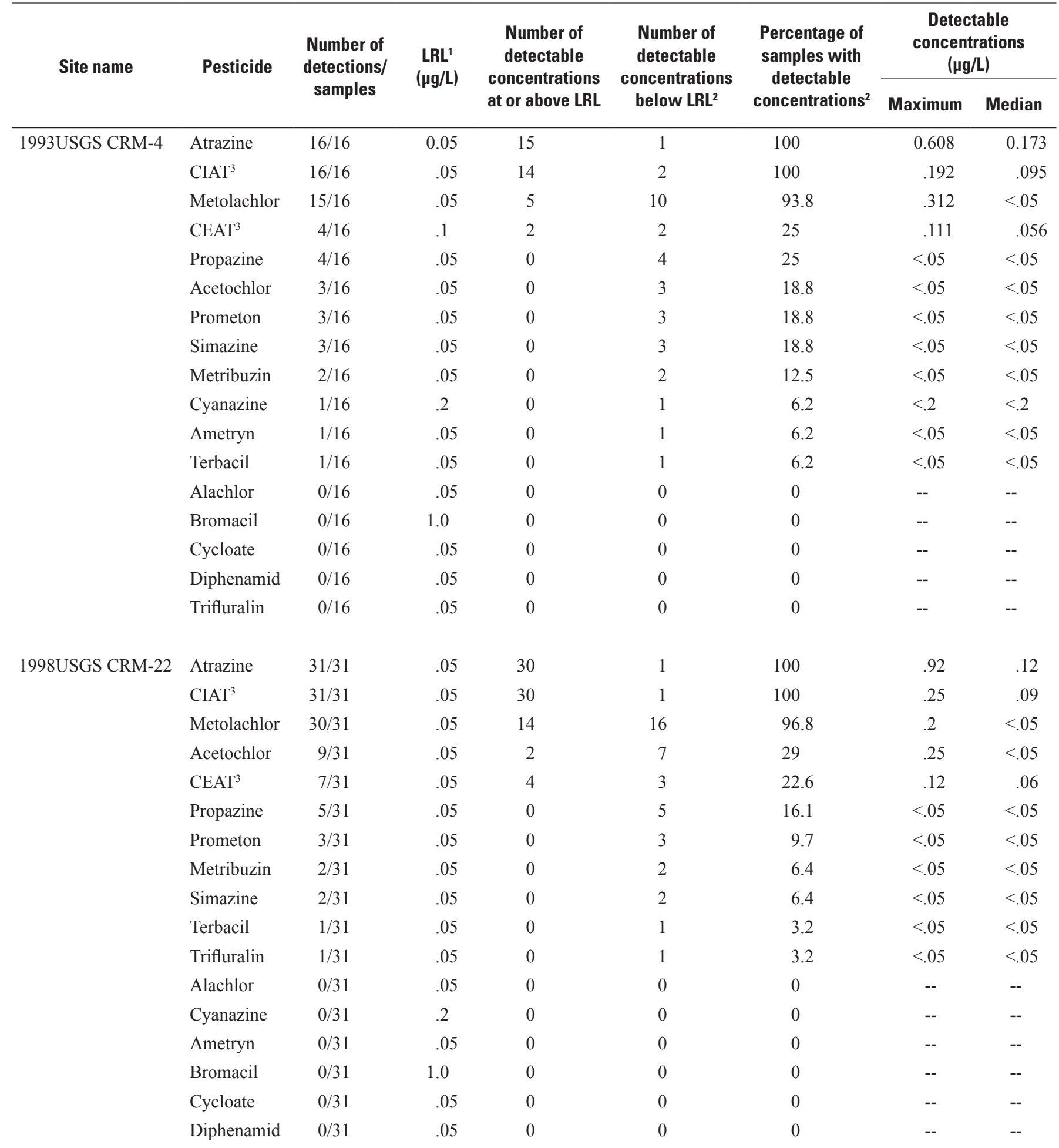


Table 19. Selected pesticides and pesticide degradates, frequency of detections in groundwater and surface-water samples by site, Cedar Rapids, lowa, calendar years 1999-2005.-Continued

[LRL, laboratory reporting level; $\mu \mathrm{g} / \mathrm{L}$, micrograms per liter; <, actual value is known to be less than value shown; --, not applicable]

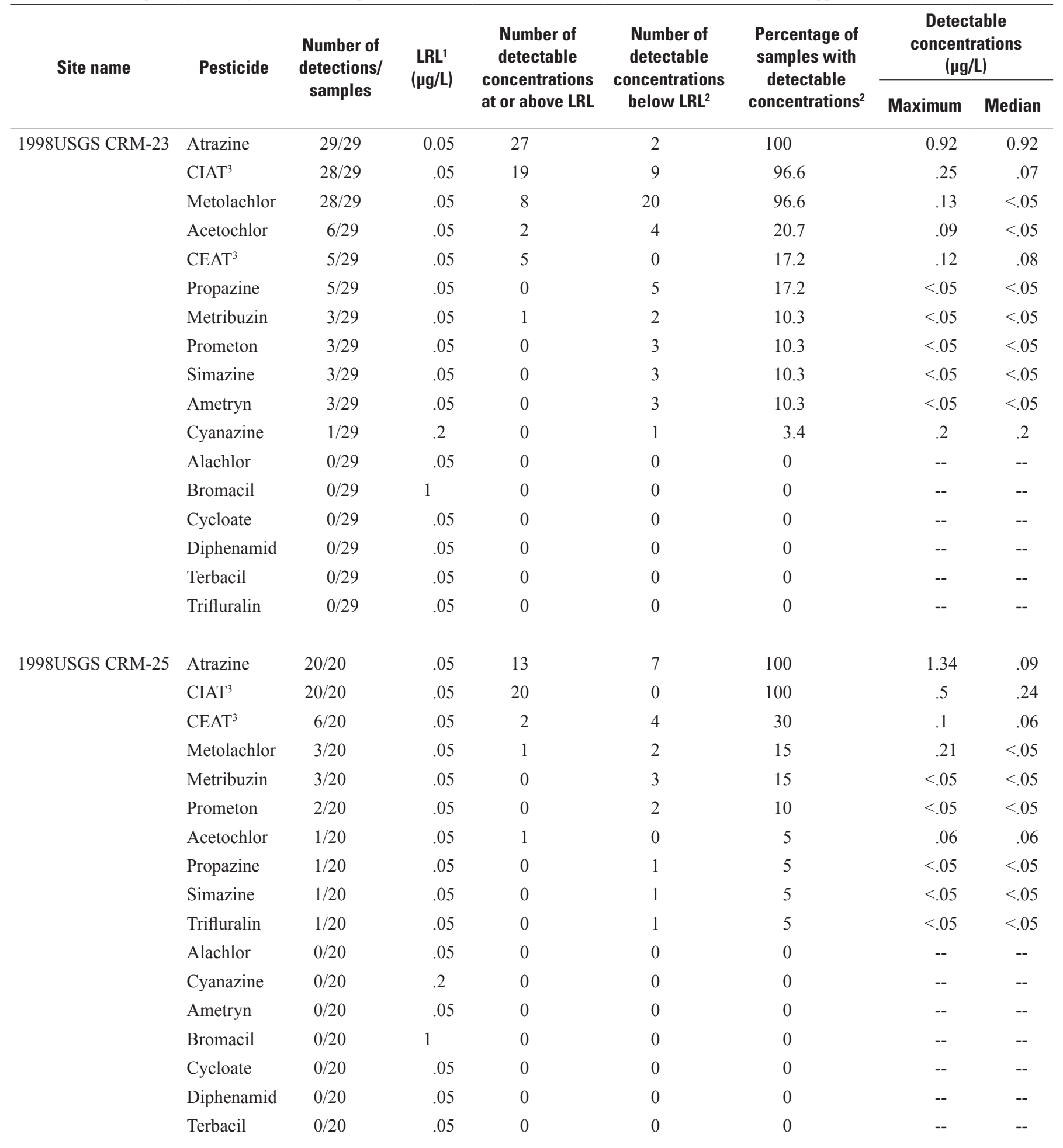


Table 19. Selected pesticides and pesticide degradates, frequency of detections in groundwater and surface-water samples by site, Cedar Rapids, lowa, calendar years 1999-2005. - Continued

[LRL, laboratory reporting level; $\mu \mathrm{g} / \mathrm{L}$, micrograms per liter; <, actual value is known to be less than value shown; --, not applicable]

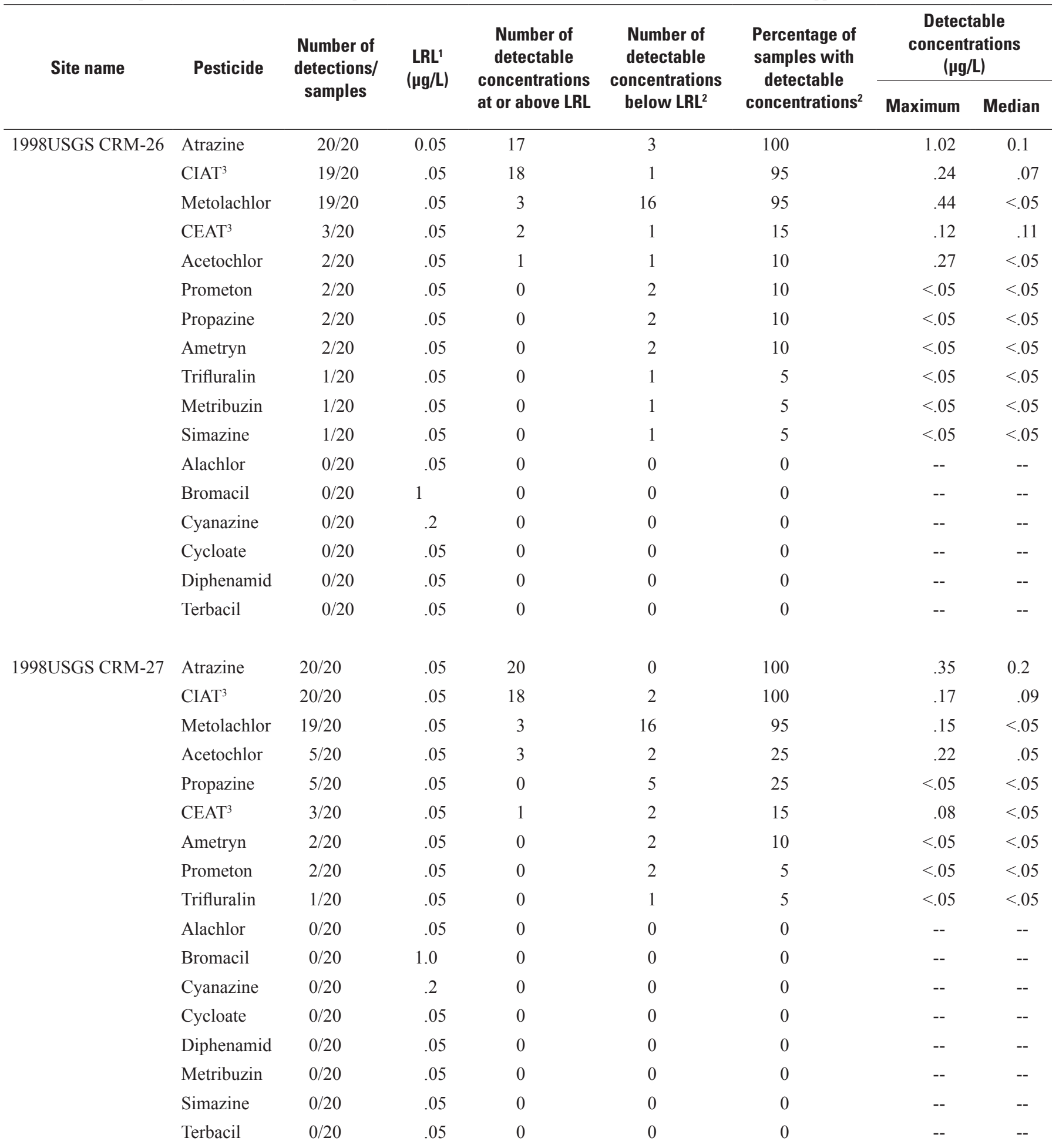


Table 19. Selected pesticides and pesticide degradates, frequency of detections in groundwater and surface-water samples by site, Cedar Rapids, lowa, calendar years 1999-2005.-Continued

[LRL, laboratory reporting level; $\mu \mathrm{g} / \mathrm{L}$, micrograms per liter; <, actual value is known to be less than value shown; --, not applicable]

\begin{tabular}{|c|c|c|c|c|c|c|c|c|}
\hline Site name & Pesticide & $\begin{array}{l}\text { Number of } \\
\text { detections/ } \\
\text { samples }\end{array}$ & $\begin{array}{l}\text { LRL'1 }^{1} \\
(\mu \mathrm{g} / \mathrm{L})\end{array}$ & $\begin{array}{c}\text { Number of } \\
\text { detectable } \\
\text { concentrations } \\
\text { at or above LRL }\end{array}$ & $\begin{array}{c}\text { Number of } \\
\text { detectable } \\
\text { concentrations } \\
\text { below } \mathrm{LRL}^{2}\end{array}$ & $\begin{array}{l}\text { Percentage of } \\
\text { samples with } \\
\text { detectable } \\
\text { concentrations }{ }^{2}\end{array}$ & \multicolumn{2}{|c|}{$\begin{array}{c}\text { Detectable } \\
\text { concentrations } \\
(\mu \mathrm{g} / \mathrm{L})\end{array}$} \\
\hline \multirow[t]{13}{*}{ 1990Seminole 14} & Atrazine & $5 / 5$ & 0.05 & 5 & 0 & 100 & 0.33 & 0.14 \\
\hline & CIAT $^{3}$ & $5 / 5$ & .05 & 3 & 2 & 100 & .1 & .06 \\
\hline & Acetochlor & $1 / 5$ & .05 & 0 & 1 & 20 & $<.05$ & $<.05$ \\
\hline & Prometon & $1 / 5$ & .05 & 0 & 1 & 20 & $<.05$ & $<.05$ \\
\hline & $\mathrm{CEAT}^{3}$ & $0 / 5$ & .05 & 0 & 0 & 0 & -- & -- \\
\hline & Alachlor & $0 / 5$ & .05 & 0 & 0 & 0 & -- & -- \\
\hline & Ametryn & $0 / 5$ & .05 & 0 & 0 & 0 & -- & -- \\
\hline & Diphenamid & $0 / 5$ & .05 & 0 & 0 & 0 & -- & -- \\
\hline & Metribuzin & $0 / 5$ & .05 & 0 & 0 & 0 & -- & -- \\
\hline & Propazine & $0 / 5$ & .05 & 0 & 0 & 0 & -- & -- \\
\hline & Simazine & $0 / 5$ & .05 & 0 & 0 & 0 & -- & -- \\
\hline & Terbacil & $0 / 5$ & .05 & 0 & 0 & 0 & -- & -- \\
\hline & Trifluralin & $0 / 5$ & .05 & 0 & 0 & 0 & -- & -- \\
\hline \multirow[t]{13}{*}{ Seminole 17} & Atrazine & $11 / 11$ & .05 & 11 & 0 & 100 & .76 & .17 \\
\hline & Prometon & $1 / 11$ & .05 & 0 & 1 & 9.1 & $<.05$ & $<.05$ \\
\hline & Propazine & $1 / 11$ & .05 & 0 & 1 & 9.1 & $<.05$ & $<.05$ \\
\hline & Simazine & $1 / 11$ & .05 & 0 & 1 & 9.1 & $<.05$ & $<.05$ \\
\hline & Alachlor & $0 / 11$ & .05 & 0 & 0 & 0 & -- & -- \\
\hline & Ametryn & $0 / 11$ & .05 & 0 & 0 & 0 & -- & -- \\
\hline & Bromacil & $0 / 11$ & 1.0 & 0 & 0 & 0 & -- & -- \\
\hline & Cyanazine & $0 / 11$ & .2 & 0 & 0 & 0 & -- & -- \\
\hline & Cycloate & $0 / 11$ & .05 & 0 & 0 & 0 & -- & -- \\
\hline & Diphenamid & $0 / 11$ & .05 & 0 & 0 & 0 & -- & -- \\
\hline & Metribuzin & $0 / 11$ & .05 & 0 & 0 & 0 & -- & -- \\
\hline & Terbacil & $0 / 11$ & .05 & 0 & 0 & 0 & -- & -- \\
\hline & Trifluralin & $0 / 11$ & .05 & 0 & 0 & 0 & -- & -- \\
\hline
\end{tabular}


Table 19. Selected pesticides and pesticide degradates, frequency of detections in groundwater and surface-water samples by site, Cedar Rapids, lowa, calendar years 1999-2005. - Continued

[LRL, laboratory reporting level; $\mu \mathrm{g} / \mathrm{L}$, micrograms per liter; <, actual value is known to be less than value shown; --, not applicable]

\begin{tabular}{|c|c|c|c|c|c|c|c|c|}
\hline Site name & Pesticide & $\begin{array}{l}\text { Number of } \\
\text { detections/ } \\
\text { samples }\end{array}$ & $\begin{array}{c}\mathrm{LRL}^{1} \\
(\mu \mathrm{g} / \mathrm{L})\end{array}$ & $\begin{array}{c}\text { Number of } \\
\text { detectable } \\
\text { concentrations } \\
\text { at or above LRL }\end{array}$ & $\begin{array}{l}\text { Number of } \\
\text { detectable } \\
\text { concentrations } \\
\text { below } \text { LRL }^{2}\end{array}$ & $\begin{array}{l}\text { Percentage of } \\
\text { samples with } \\
\text { detectable } \\
\text { concentrations }^{2}\end{array}$ & \multicolumn{2}{|c|}{$\begin{array}{c}\text { Detectable } \\
\text { concentrations } \\
(\mu \mathrm{g} / \mathrm{L})\end{array}$} \\
\hline \multirow[t]{13}{*}{ 1991Seminole 18} & Atrazine & $5 / 5$ & 0.05 & 5 & 0 & 100 & 0.199 & 0.086 \\
\hline & CIAT $^{3}$ & $5 / 5$ & .05 & 4 & 1 & 100 & .086 & .056 \\
\hline & CEAT $^{3}$ & $0 / 5$ & .05 & 0 & 0 & 0 & -- & -- \\
\hline & Acetochlor & $0 / 5$ & .05 & 0 & 0 & 0 & -- & -- \\
\hline & Alachlor & $0 / 5$ & .05 & 0 & 0 & 0 & -- & -- \\
\hline & Ametryn & $0 / 5$ & .05 & 0 & 0 & 0 & -- & -- \\
\hline & Bromacil & $0 / 5$ & .05 & 0 & 0 & 0 & -- & -- \\
\hline & Metribuzin & $0 / 5$ & .05 & 0 & 0 & 0 & -- & -- \\
\hline & Prometon & $0 / 5$ & .05 & 0 & 0 & 0 & -- & -- \\
\hline & Propazine & $0 / 5$ & .05 & 0 & 0 & 0 & -- & -- \\
\hline & Simazine & $0 / 5$ & .05 & 0 & 0 & 0 & -- & -- \\
\hline & Terbacil & $0 / 5$ & .05 & 0 & 0 & 0 & -- & -- \\
\hline & Trifluralin & $0 / 5$ & .05 & 0 & 0 & 0 & -- & -- \\
\hline \multirow[t]{11}{*}{ Seminole Ranney 1} & Atrazine & $10 / 10$ & .05 & 10 & 0 & 100 & 1.040 & .128 \\
\hline & Simazine & $1 / 10$ & .05 & 0 & 1 & 10 & $<.05$ & $<.05$ \\
\hline & Alachlor & $0 / 10$ & .05 & 0 & 0 & 0 & -- & -- \\
\hline & Ametryn & $0 / 10$ & .05 & 0 & 0 & 0 & -- & -- \\
\hline & Bromacil & $0 / 10$ & 1.0 & 0 & 0 & 0 & -- & -- \\
\hline & Cyanazine & $0 / 10$ & .2 & 0 & 0 & 0 & -- & -- \\
\hline & Cycloate & $0 / 10$ & .05 & 0 & 0 & 0 & -- & -- \\
\hline & Diphenamid & $0 / 10$ & .05 & 0 & 0 & 0 & -- & -- \\
\hline & Metribuzin & $0 / 10$ & .05 & 0 & 0 & 0 & -- & -- \\
\hline & Terbacil & $0 / 10$ & .05 & 0 & 0 & 0 & -- & -- \\
\hline & Trifluralin & $0 / 10$ & .05 & 0 & 0 & 0 & -- & -- \\
\hline
\end{tabular}


Table 19. Selected pesticides and pesticide degradates, frequency of detections in groundwater and surface-water samples by site, Cedar Rapids, lowa, calendar years 1999-2005.-Continued

[LRL, laboratory reporting level; $\mu \mathrm{g} / \mathrm{L}$, micrograms per liter; <, actual value is known to be less than value shown; --, not applicable]

\begin{tabular}{|c|c|c|c|c|c|c|c|c|}
\hline Site name & Pesticide & $\begin{array}{c}\text { Number of } \\
\text { detections/ } \\
\text { samples }\end{array}$ & $\begin{array}{c}\mathrm{LRL}^{1} \\
(\mu \mathrm{g} / \mathrm{L})\end{array}$ & $\begin{array}{c}\text { Number of } \\
\text { detectable } \\
\text { concentrations } \\
\text { at or above LRL }\end{array}$ & $\begin{array}{c}\text { Number of } \\
\text { detectable } \\
\text { concentrations } \\
\text { below } \mathrm{LRL}^{2}\end{array}$ & $\begin{array}{l}\text { Percentage of } \\
\text { samples with } \\
\text { detectable } \\
\text { concentrations }{ }^{2}\end{array}$ & \multicolumn{2}{|c|}{$\begin{array}{c}\text { Detectable } \\
\text { concentrations } \\
(\mu \mathrm{g} / \mathrm{L})\end{array}$} \\
\hline \multirow[t]{14}{*}{ Seminole Ranney 2} & Atrazine & $9 / 9$ & 0.05 & 9 & 0 & 100 & 1.1 & 0.13 \\
\hline & CIAT $^{3}$ & $9 / 9$ & .05 & 7 & 2 & 100 & .21 & .07 \\
\hline & $\mathrm{CEAT}^{3}$ & $3 / 9$ & .06 & 1 & 2 & 33.3 & .07 & $<.05$ \\
\hline & Acetochlor & $3 / 9$ & .05 & 1 & 2 & 33.3 & .07 & $<.05$ \\
\hline & Propazine & $2 / 9$ & .05 & 0 & 2 & 22.2 & $<.05$ & $<.05$ \\
\hline & Simazine & $2 / 9$ & .05 & 0 & 2 & 22.2 & $<.05$ & $<.05$ \\
\hline & Prometon & $1 / 9$ & .05 & 0 & 1 & 11.1 & $<.05$ & $<.05$ \\
\hline & Bromacil & $0 / 9$ & .05 & 0 & 0 & 0 & -- & -- \\
\hline & Cyanazine & $0 / 9$ & .2 & 0 & 0 & 0 & -- & -- \\
\hline & Cycloate & $0 / 9$ & .05 & 0 & 0 & 0 & -- & -- \\
\hline & Diphenamid & $0 / 9$ & .05 & 0 & 0 & 0 & -- & -- \\
\hline & Metribuzin & $0 / 9$ & .05 & 0 & 0 & 0 & -- & -- \\
\hline & Terbacil & $0 / 9$ & .05 & 0 & 0 & 0 & -- & -- \\
\hline & Trifluralin & $0 / 9$ & .05 & 0 & 0 & 0 & -- & -- \\
\hline \multirow[t]{11}{*}{ Edgewood Ranney } & Atrazine & $12 / 12$ & .05 & 12 & 0 & 100 & 1.75 & .15 \\
\hline & CEAT $^{3}$ & $1 / 12$ & .05 & 1 & 0 & 8.3 & .1 & .1 \\
\hline & Alachlor & $0 / 12$ & .05 & 0 & 0 & 0 & -- & -- \\
\hline & Ametryn & $0 / 12$ & .05 & 0 & 0 & 0 & -- & -- \\
\hline & Bromacil & $0 / 12$ & 1.0 & 0 & 0 & 0 & -- & -- \\
\hline & Cyanazine & $0 / 12$ & .2 & 0 & 0 & 0 & -- & -- \\
\hline & Cycloate & $0 / 12$ & .05 & 0 & 0 & 0 & -- & -- \\
\hline & Diphenamid & $0 / 12$ & .05 & 0 & 0 & 0 & -- & -- \\
\hline & Metribuzin & $0 / 12$ & .05 & 0 & 0 & 0 & -- & -- \\
\hline & Terbacil & $0 / 12$ & .05 & 0 & 0 & 0 & -- & -- \\
\hline & Trifluralin & $0 / 12$ & .05 & 0 & 0 & 0 & -- & -- \\
\hline
\end{tabular}


Table 19. Selected pesticides and pesticide degradates, frequency of detections in groundwater and surface-water samples by site, Cedar Rapids, lowa, calendar years 1999-2005. - Continued

[LRL, laboratory reporting level; $\mu \mathrm{g} / \mathrm{L}$, micrograms per liter; <, actual value is known to be less than value shown; --, not applicable]

\begin{tabular}{|c|c|c|c|c|c|c|c|c|}
\hline Site name & Pesticide & $\begin{array}{c}\text { Number of } \\
\text { detections/ } \\
\text { samples }\end{array}$ & $\begin{array}{l}\mathrm{LRL}^{1} \\
(\mu \mathrm{g} / \mathrm{L})\end{array}$ & $\begin{array}{c}\text { Number of } \\
\text { detectable } \\
\text { concentrations } \\
\text { at or above LRL }\end{array}$ & $\begin{array}{c}\text { Number of } \\
\text { detectable } \\
\text { concentrations } \\
\text { below LRL }\end{array}$ & $\begin{array}{l}\text { Percentage of } \\
\text { samples with } \\
\text { detectable } \\
\text { concentrations }\end{array}$ & \multicolumn{2}{|c|}{$\begin{array}{c}\text { Detectable } \\
\text { concentrations } \\
(\mu \mathrm{g} / \mathrm{L})\end{array}$} \\
\hline \multirow[t]{14}{*}{ Seminole Ranney 4} & Atrazine & $11 / 11$ & 0.05 & 11 & 0 & 100 & 0.97 & 0.13 \\
\hline & CIAT $^{3}$ & $11 / 11$ & .05 & 11 & 0 & 100 & .2 & .06 \\
\hline & $\mathrm{CEAT}^{3}$ & $2 / 11$ & .05 & 1 & 1 & 18.2 & .07 & $<.05$ \\
\hline & Acetochlor & $2 / 11$ & .05 & 2 & 0 & 18.2 & .1 & .08 \\
\hline & Prometon & $2 / 11$ & .05 & 0 & 2 & 18.2 & $<.05$ & $<.05$ \\
\hline & Propazine & $2 / 11$ & .05 & 0 & 2 & 18.2 & $<.05$ & $<.05$ \\
\hline & Simazine & $1 / 11$ & .05 & 0 & 1 & 9.1 & $<.05$ & $<.05$ \\
\hline & Bromacil & $0 / 11$ & 1.0 & 0 & 0 & 0 & -- & -- \\
\hline & Cyanazine & $0 / 11$ & .2 & 0 & 0 & 0 & -- & -- \\
\hline & Cycloate & $0 / 11$ & .05 & 0 & 0 & 0 & -- & -- \\
\hline & Diphenamid & $0 / 11$ & .05 & 0 & 0 & 0 & -- & -- \\
\hline & Metribuzin & $0 / 11$ & .05 & 0 & 0 & 0 & -- & -- \\
\hline & Terbacil & $0 / 11$ & .05 & 0 & 0 & 0 & -- & -- \\
\hline & Trifluralin & $0 / 11$ & .05 & 0 & 0 & 0 & -- & -- \\
\hline \multirow{12}{*}{$\begin{array}{l}\text { Cedar Rapids Water- } \\
\text { works }\end{array}$} & CIAT $^{3}$ & $31 / 31$ & .05 & 28 & 3 & 100 & .22 & .07 \\
\hline & Prometon & $4 / 31$ & .05 & 0 & 4 & 12.9 & $<.05$ & $<.05$ \\
\hline & Simazine & $3 / 31$ & .05 & 0 & 3 & 9.7 & $<.05$ & $<.05$ \\
\hline & Ametryn & $3 / 31$ & .05 & 0 & 3 & 9.7 & $<.05$ & $<.05$ \\
\hline & Bromacil & $1 / 27$ & 1.0 & 0 & 1 & 3.7 & $<1$ & $<1$ \\
\hline & Metribuzin & $1 / 31$ & .05 & 0 & 1 & 3.2 & $<.05$ & $<.05$ \\
\hline & Alachlor & $0 / 31$ & .05 & 0 & 0 & 0 & -- & -- \\
\hline & Cyanazine & $0 / 31$ & .2 & 0 & 0 & 0 & -- & -- \\
\hline & Cycloate & $0 / 27$ & .05 & 0 & 0 & 0 & -- & -- \\
\hline & Diphenamid & $0 / 27$ & .05 & 0 & 0 & 0 & -- & -- \\
\hline & Terbacil & $0 / 27$ & .05 & 0 & 0 & 0 & -- & -- \\
\hline & Trifluralin & $0 / 27$ & .05 & 0 & 0 & 0 & -- & -- \\
\hline
\end{tabular}


Table 19. Selected pesticides and pesticide degradates, frequency of detections in groundwater and surface-water samples by site, Cedar Rapids, lowa, calendar years 1999-2005.

[LRL, laboratory reporting level; $\mu \mathrm{g} / \mathrm{L}$, micrograms per liter; <, actual value is known to be less than value shown; --, not applicable]

\begin{tabular}{|c|c|c|c|c|c|c|c|c|}
\hline Site name & Pesticide & $\begin{array}{l}\text { Number of } \\
\text { detections/ } \\
\text { samples }\end{array}$ & $\begin{array}{l}\operatorname{LRL}^{1} \\
(\mu \mathrm{g} / \mathrm{L})\end{array}$ & $\begin{array}{c}\text { Number of } \\
\text { detectable } \\
\text { concentrations } \\
\text { at or above LRL }\end{array}$ & $\begin{array}{c}\text { Number of } \\
\text { detectable } \\
\text { concentrations } \\
\text { below LRL² }\end{array}$ & $\begin{array}{l}\text { Percentage of } \\
\text { samples with } \\
\text { detectable } \\
\text { concentrations }{ }^{2}\end{array}$ & \multicolumn{2}{|c|}{$\begin{array}{c}\text { Detectable } \\
\text { concentrations } \\
(\mu \mathrm{g} / \mathrm{L})\end{array}$} \\
\hline \multirow{13}{*}{$\begin{array}{l}\text { Cedar River at } \\
\text { Edgewood Road }\end{array}$} & Atrazine & $40 / 40$ & 0.05 & 36 & 4 & 100 & 4.50 & 0.20 \\
\hline & Metolachlor & $39 / 40$ & .05 & 26 & 13 & 97.5 & .89 & .07 \\
\hline & Acetochlor & $15 / 40$ & .05 & 13 & 2 & 37.5 & 1.0 & .18 \\
\hline & CEAT $^{3}$ & $12 / 38$ & .05 & 11 & 1 & 31.6 & .3 & $<.3$ \\
\hline & Propazine & $9 / 38$ & .05 & 1 & 8 & 23.7 & $<.05$ & $<.05$ \\
\hline & Alachlor & $8 / 40$ & .05 & 3 & 5 & 20 & .11 & $<.05$ \\
\hline & Simazine & $4 / 40$ & .05 & 0 & 4 & 10 & $<.05$ & $<.05$ \\
\hline & Ametryn & $3 / 31$ & .05 & 0 & 3 & 9.7 & $<.05$ & $<.05$ \\
\hline & Bromacil & $1 / 27$ & 1.0 & 0 & 1 & 3.7 & $<1$ & $<1$ \\
\hline & Cycloate & $0 / 27$ & .05 & 0 & 0 & 0 & -- & -- \\
\hline & Diphenamid & $0 / 27$ & .05 & 0 & 0 & 0 & -- & -- \\
\hline & Terbacil & $0 / 27$ & .05 & 0 & 0 & 0 & -- & -- \\
\hline & Trifluralin & $0 / 27$ & .05 & 0 & 0 & 0 & -- & -- \\
\hline \multirow{12}{*}{$\begin{array}{l}\text { Wetland Pond at } \\
\text { CRM-27 }\end{array}$} & Atrazine & $5 / 5$ & .05 & 5 & 0 & 100 & .53 & .24 \\
\hline & Metribuzin & $1 / 5$ & .05 & 0 & 1 & 20 & $<.05$ & $<.05$ \\
\hline & Propazine & $1 / 5$ & .05 & 0 & 1 & 20 & $<.05$ & $<.05$ \\
\hline & Terbacil & $1 / 5$ & .05 & 0 & 1 & 20 & $<.05$ & $<.05$ \\
\hline & Alachlor & $0 / 5$ & .05 & 0 & 0 & 0 & -- & -- \\
\hline & Bromacil & $0 / 5$ & 1.0 & 0 & 0 & 0 & -- & -- \\
\hline & Cyanazine & $0 / 5$ & .05 & 0 & 0 & 0 & -- & -- \\
\hline & Cycloate & $0 / 5$ & .05 & 0 & 0 & 0 & -- & -- \\
\hline & Diphenamid & $0 / 5$ & .05 & 0 & 0 & 0 & -- & -- \\
\hline & Prometon & $0 / 5$ & .05 & 0 & 0 & 0 & -- & -- \\
\hline & Simazine & $0 / 5$ & .05 & 0 & 0 & 0 & -- & -- \\
\hline & Trifluralin & $0 / 5$ & .05 & 0 & 0 & 0 & -- & -- \\
\hline
\end{tabular}

\footnotetext{
${ }^{1}$ Highest laboratory reporting level for period of record.
}

${ }^{2}$ Includes both quantifiable and unquantifiable (estimated) concentrations. Quantifiable detections exist for concentrations that exceeded lower laboratory reporting levels during period of record.

${ }^{3}$ Atrazine degradates: 2-Chloro-4-amino-6-isopropyl-amino-striazine (CIAT) and 2-Chloro-4-ethylamino-6-amino-s-triazine (CEAT) 
Table 20. Pesticide degradates data by site, Cedar Rapids, lowa, calendar years 1999-2005.

$[\mu \mathrm{g} / \mathrm{L}$, micrograms per liter; $<$, actual value is known to be less than value shown; --, no data]

\begin{tabular}{|c|c|c|c|c|c|c|c|}
\hline Site name & $\begin{array}{c}\text { Date } \\
\text { (year, } \\
\text { month, } \\
\text { day) }\end{array}$ & $\begin{array}{c}\text { Time } \\
\text { (24-hour) }\end{array}$ & Record number & $\begin{array}{c}\text { Acetochlor } \\
\text { ESA } \\
(61029) \\
\text { (ug/L) }\end{array}$ & $\begin{array}{c}\text { Acetochlor } \\
\text { OA } \\
(61030) \\
\text { (ug/L) }\end{array}$ & $\begin{array}{c}\text { Acetocholor } \\
\text { SAA } \\
\text { (62847) } \\
\text { (ug/L) }\end{array}$ & $\begin{array}{c}\text { Alachlor } \\
\text { ESA } \\
\text { (50009) } \\
\text { (ug/L) }\end{array}$ \\
\hline 1998USGS CRM-22 & 20050809 & 1210 & 0050046701 & 0.3 & 0.1 & 0.02 & 0.02 \\
\hline 1998USGS CRM-23 & 20050809 & 1330 & 0050046801 & .4 & .1 & $<.02$ & $<.02$ \\
\hline Seminole 17 & 20050809 & 1650 & 0050047001 & .7 & .3 & .02 & .02 \\
\hline Seminole Ranney 1 & 20050811 & 1200 & 0050037901 & .3 & .1 & $<.02$ & .03 \\
\hline \multirow{3}{*}{ Waterworks Plant } & 19990629 & 1050 & 9990176701 & 1.2 & .7 & -- & -- \\
\hline & 19990715 & 1200 & 9990109001 & .9 & .7 & -- & -- \\
\hline & 19990817 & 0910 & 9990177201 & 1.1 & .6 & -- & -- \\
\hline \multirow[t]{5}{*}{ Cedar River at Edgewood Road } & 19990615 & 0945 & 9990176101 & 2.6 & 2.7 & -- & -- \\
\hline & 19990629 & 1135 & 9990176501 & 1.2 & .6 & -- & -- \\
\hline & 19990715 & 1045 & 9990176901 & 1 & 1.1 & -- & -- \\
\hline & 19990817 & 1025 & 9990177101 & .8 & .3 & -- & -- \\
\hline & 20031024 & 1500 & 0040001601 & $<.02$ & $<.02$ & $<.02$ & .02 \\
\hline
\end{tabular}


Table 20. Pesticide degradates data by site, Cedar Rapids, lowa, calendar years 1999-2005._Continued

$[\mu \mathrm{g} / \mathrm{L}$, micrograms per liter; <, actual value is known to be less than value shown; --, no data]

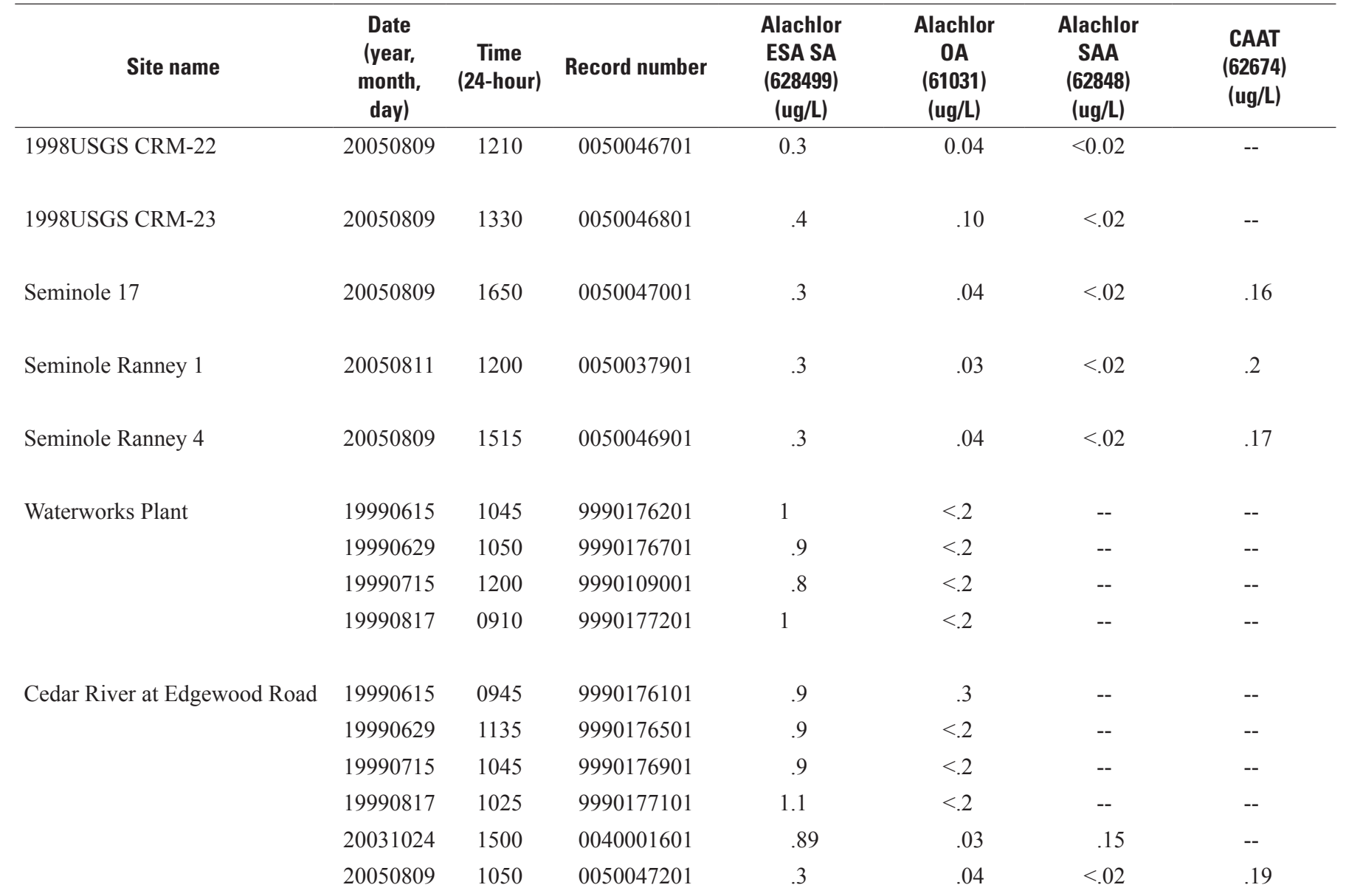


Table 20. Pesticide degradates data by site, Cedar Rapids, lowa, calendar years 1999-2005. - Continued

$[\mu \mathrm{g} / \mathrm{L}$, micrograms per liter; $<$, actual value is known to be less than value shown; --, no data]

\begin{tabular}{|c|c|c|c|c|c|c|c|}
\hline Site name & $\begin{array}{l}\text { Date } \\
\text { (year, } \\
\text { month, } \\
\text { day) }\end{array}$ & $\begin{array}{c}\text { Time } \\
\text { (24-hour) }\end{array}$ & Record number & $\begin{array}{c}\text { Dechlorometolchlor } \\
(63780) \\
(\mathrm{ug} / \mathrm{L})\end{array}$ & $\begin{array}{l}\text { Deethyl- } \\
\text { cyanazine } \\
\text { (61750) } \\
\text { (ug/L) }\end{array}$ & $\begin{array}{c}\text { Dimethe- } \\
\text { namid ESA } \\
\text { (61951) } \\
\text { (ug/L) }\end{array}$ & $\begin{array}{c}\text { Metolachlor } \\
\text { ESA } \\
(61043) \\
\text { (ug/L) }\end{array}$ \\
\hline 1998USGS CRM-23 & 20050809 & 1330 & 0050046801 & .02 & .04 & .03 & 1.2 \\
\hline Seminole 17 & 20050809 & 1650 & 0050047001 & $<.02$ & $<.025$ & .05 & 1.3 \\
\hline Seminole Ranney 1 & 20050811 & 1200 & 0050037901 & $<.02$ & $<.025$ & .03 & 1 \\
\hline Seminole Ranney 4 & 20050809 & 1515 & 0050046901 & $<.02$ & .04 & .04 & 1.3 \\
\hline \multirow{3}{*}{ Waterworks Plant } & 19990629 & 1050 & 9990176701 & -- & -- & -- & 3 \\
\hline & 19990715 & 1200 & 9990109001 & -- & -- & -- & 2.5 \\
\hline & 19990817 & 0910 & 9990177201 & -- & -- & -- & 3.3 \\
\hline \multirow[t]{5}{*}{ Cedar River at Edgewood Road } & 19990615 & 0945 & 9990176101 & -- & -- & -- & 3.9 \\
\hline & 19990629 & 1135 & 9990176501 & -- & -- & -- & 3.3 \\
\hline & 19990715 & 1045 & 9990176901 & -- & -- & -- & 2.8 \\
\hline & 19990817 & 1025 & 9990177101 & -- & -- & -- & 3.1 \\
\hline & 20031024 & 1500 & 0040001601 & -- & $<.025$ & $<.02$ & 0.97 \\
\hline
\end{tabular}


52 Selected Water-Quality Data from the Cedar River and Cedar Rapids Well Fields, Cedar Rapids, lowa, 1999-2005

Table 20. Pesticide degradates data by site, Cedar Rapids, lowa, calendar years 1999-2005. —Continued

[ $\mu \mathrm{g} / \mathrm{L}$, micrograms per liter; <, actual value is known to be less than value shown; --, no data]

\begin{tabular}{|c|c|c|c|c|c|c|c|}
\hline Site name & $\begin{array}{c}\text { Date } \\
\text { (year, } \\
\text { month, } \\
\text { day) }\end{array}$ & $\begin{array}{c}\text { Time } \\
\text { (24-hour) }\end{array}$ & Record number & $\begin{array}{c}\text { Metolachlor } \\
\text { OA } \\
\text { (61044) } \\
\text { (ug/L) }\end{array}$ & $\begin{array}{l}\mathrm{N} \text { (Ethmetphen)ox } \\
\text { (62850) (ug/L) }\end{array}$ & $\begin{array}{c}\text { OEAT } \\
\text { (62678) } \\
\text { (ug/L) }\end{array}$ & $\begin{array}{c}\text { OIET } \\
\text { (50355) } \\
\text { (ug/L) }\end{array}$ \\
\hline 1998USGS CRM-22 & 20050809 & 1210 & 0050046701 & 0.2 & 0.08 & $<0.025$ & 0.07 \\
\hline 1998USGS CRM-23 & 20050809 & 1330 & 0050046801 & .2 & .1 & $<.025$ & .19 \\
\hline Seminole 17 & 20050809 & 1650 & 0050047001 & .3 & .12 & $<.025$ & .07 \\
\hline Seminole Ranney 1 & 20050811 & 1200 & 0050037901 & .2 & .09 & $<.025$ & $<.025$ \\
\hline Seminole Ranney 4 & 20050809 & 1515 & 0050046901 & .2 & .09 & $<.025$ & .11 \\
\hline \multirow[t]{4}{*}{ Waterworks Plant } & 19990615 & 1045 & 9990176201 & .5 & -- & -- & $<.200$ \\
\hline & 19990629 & 1050 & 9990176701 & .7 & -- & -- & $<.200$ \\
\hline & 19990715 & 1200 & 9990109001 & .6 & -- & -- & $<.200$ \\
\hline & 19990817 & 0910 & 9990177201 & .7 & -- & -- & $<.200$ \\
\hline \multirow[t]{6}{*}{ Cedar River at Edgewood Road } & 19990615 & 0945 & 9990176101 & .9 & -- & -- & .56 \\
\hline & 19990629 & 1135 & 9990176501 & .6 & -- & -- & $<.200$ \\
\hline & 19990715 & 1045 & 9990176901 & .6 & -- & -- & $<.200$ \\
\hline & 19990817 & 1025 & 9990177101 & .5 & -- & -- & $<.200$ \\
\hline & 20031024 & 1500 & 0040001601 & .11 & .11 & .03 & .05 \\
\hline & 20050809 & 1050 & 0050047201 & .1 & .08 & $<.025$ & .08 \\
\hline
\end{tabular}

Publishing support provided by:

Rolla Publishing Service Center

For more information concerning this publication, contact:

Director, USGS lowa Water Science Center

400 South Clinton Street, Room 269

lowa City, IA 52244-1230

(319) 337-4191

Or visit the lowa Water Science Center Web site at:

http://ia.water.usgs.gov 

